JOSÉ CARLOS CARREIRA

\title{
POSICIONAMENTO SEMIÓTICO DINÂMICO DE UMA MARCA DE AUTOMÓVEL.
}

Escola de Comunicações e Artes - USP

São Paulo - 2008 
JOSÉ CARLOS CARREIRA

\title{
POSICIONAMENTO SEMIÓTICO DINÂMICO DE UMA MARCA DE AUTOMÓVEL.
}

\begin{abstract}
Tese apresentada ao Programa de PósGraduação, stricto sensu, em Ciências da Comunicação, área de concentração: Interfaces Sociais da Comunicação, Linha de pesquisa Publicidade e Propaganda da Escola de Comunicações e Artes da Universidade de São Paulo, como exigência parcial para obtenção do título de Doutor em Comunicação, sob orientação do Prof. Dr. Ivan Santo Barbosa.
\end{abstract}

Escola de Comunicações e Artes - USP

São Paulo - 2008 
$1^{\circ}$. Examinador

$2^{\circ}$. Examinador

$3^{\circ}$. Examinador

$4^{\circ}$. Examinador

$5^{\circ}$. Examinador

(orientador) 
Dedicatória

À minha esposa e filho que sempre me apoiaram nessa minha trajetória. 


\section{SINOPSE}

O objetivo desta pesquisa foi estudar a tensão entre manter um posicionamento de marcas ou atualizá-lo de acordo com as possíveis alterações no âmbito do contexto social. $\mathrm{Na}$ administração de marketing é prática manter certo posicionamento na comunicação com o intuito de mostrar consistência nas mensagens publicitárias. Entretanto, observa-se que as rápidas e constantes mudanças nos valores da sociedade vêm desafiando o gestor da marca a buscar compreender a dinâmica dos significados que circula entre os indivíduos, e como ela influencia na imagem da marca.

O método utilizado para verificar uma dinâmica no posicionamento de marcas na comunicação, foi a análise semiótica das campanhas publicitárias do EcoSport, desde o seu lançamento até a sua última modificação em 2007. A escolha de um automóvel como objeto para verificar a dinâmica do posicionamento de marca se deu pela complexidade de sua comunicação, bem como pelos atuais conflitos ambientais que essa mercadoria vem sendo alvo.

Os resultados obtidos confirmam uma necessidade de atualização dos conceitos fundamentais do posicionamento de marca, porém sugerem alguns limites nessas mudanças, levando em consideração os quatros quadrante de valorização de consumo de Jean-Marie Floch. No processo de elaboração desta pesquisa, mais uma vez, verificou-se a contribuição valiosa da semiótica como ferramenta indispensável para o administrador da marca.

Palavras chave: POSICIONAMENTO DE MARCA - COMUNICAÇÃO SEMIÓTICA - SIGNIFICADOS - AUTOMÓVEL. 


\section{ABSTRACT}

This paper have had as main objective understand the tension between to keep or to move the brand positioning according to the probable changes in the social context. In the marketing administration world is current to keep the main concept in the positioning in order to show consistency in all marketing messages. However, is possible to see that constantly and fast changes have been challenging the brand manager to understand the meanings dynamism that act in the market, and how can it influence the brand image.

The methodology used to verify the dynamics of the brand positioning in the communication process was the semiotic analysis of the EcoSport advertising campaign, since its launch till its last face-lift in 2007. The reason to choose an automobile as the object to verify the brand positioning dynamics was due the communication complexity as well as to the environmental conflicts that this merchandise has been suffering lately.

The results confirm the necessity that brand positioning main concepts has to be up-dated frequently, following the changes in the social context. However, these changes have some limits. The changes are limited by the boundaries of the JeanMarie Floch consumption valorized square. During this research, once more, could be demonstrated the semiotic contribution for the brand manager.

Key words: BRAND POSITIONING; COMUNICATION; SEMIOTIC; MEANING; AUTOMOBILE. 
stop

a vida parou

ou foi o automóvel?

Carlos Drummond de Andrade 


\section{SUMÁRIO}

DEDICATÓRIA I

SINOPSE II

ABSTRACT III

$\begin{array}{ll}\text { INTRODUÇÃO } & 10\end{array}$

1. POSICIONAMENTO SEMIÓTICO DE MARCAS.

1.1. Sistema da marca. 15

1.2. Posicionamento de marca. $\quad 25$

1.3. Semiótica e o posicionamento de marca. 30

1.3.1. Posicionamento semiótico de marca. 41

1.3.2. Procedimento para enunciado do posicionamento. 59

2. A CULTURA DE CONSUMO E O AUTOMÓVEL. 65

2.1. Cultura de consumo na sociedade contemporânea. 66

$\begin{array}{ll}\text { 2.2. Sobre o automóvel. } & 71\end{array}$

2.3. Os significados do automóvel no Brasil.

3. O SISTEMA DE VALORIZAÇÃO DO CONSUMO DE VEÍCULOS UTILITÁRIOS ESPORTIVOS NO BRASIL.

3.1. Mercado brasileiro dos utilitários esportivos.

3.2. Axiologia do consumo de veículos utilitários esportivos. $\quad 90$

3.3. O discurso dos utilitários esportivos na publicidade brasileira. $\quad 94$ 
4. A DINÂMICA DO POSICIONAMENTO DE MARCAS. 99

4.1. A dinâmica do mercado. 100

4.2. A dinâmica da marca. 103

4.3. A dinâmica do público receptor. 104

4.4. Conceito do posicionamento dinâmico. 105

5. ANÁLISE DA DINÂMICA DO POSICIONAMENTO DO EcoSport. 110

5.1. Lançamento do EcoSport. 111

5.2. Análise semiótica da dinâmica do posicionamento. 117

6. CONCLUSÕES E RECOMENDAÇÕES PARA OS GESTORES DE MARCAS EM GERAL. 152

6.1.Pontos fortes e limitações. $\quad 156$

6.2. Recomendações. 159

BIBLIOGRAFIA E MATERIAIS PUBLICADOS. 160

GLOSSÁRIO. 165

ANEXOS. 168 


\section{INTRODUÇÃO}

A presente pesquisa foi motivada pelo encontro de experiências acadêmicas e profissionais, tendo em vista a comunicação publicitária de marcas, procurando agregar à prática do marketing conhecimentos e metodologias da semiótica, com o intuito de tratar o gerenciamento de marcas como uma função que considere - além de todas as variáveis já estabelecidas na prática e nos compêndios relativos à administração empresarial - noções sobre a dinâmica dos significados na cultura de consumo contemporânea, mais especificamente no mundo automotivo. E, isto posto, estabelecer, por fim, uma metodologia de construção do posicionamento de uma marca de automóvel.

Do ponto de vista mercadológico e empresarial, o gerenciamento eficaz de marcas tem como foco agregar valor a este ativo. A correta ponderação entre oferecer valor para os clientes e angariar valor para a empresa é o fundamento desta função.

A marca em si, com seu nome e sua logotipía, sintetiza sua identidade, ou seja, todos os atributos que a empresa colecionou para seus ativos e suas mercadorias, as relações com seus funcionários, com o poder público, com o mercado e com a sociedade. Tal identidade é interpretada pelos consumidores com base na experiência própria (ou de terceiros) e na comunicação mercadológica.

O que fica dessa interpretação na mente dos consumidores, como receptores da experiência com a mercadoria e da comunicação mercadológica, chama-se imagem da marca. Quanto mais positiva e inspiradora for esta imagem, mais valorizada é a marca e conseqüentemente a empresa e suas mercadorias.

A marca constitui, então, um signo que representa a empresa, suas mercadorias e todo o estoque de conceitos e associações gerados na mente do público receptor, fruto da experiência com a mercadoria, da comunicação mercadológica (incluindo aqui as atividades de relações públicas) e de outras interações.

É, pois, a comunicação mercadológica que tem a função de transmitir as características funcionais de destaque da mercadoria, bem como, dependendo do 
tipo de mercadoria, de criar uma dimensão simbólica, de natureza emocional, revestindo-a com significados aspirados pelo seu público, tornando-a desejável.

Nessa comunicação mercadológica o conceito fundamental que vai ordenar os discursos da empresa é resultado do processo de posicionamento de marca, processo este que procura sintetizar os benefícios funcionais e as possibilidades emocionais a serem associadas à marca e sua mercadoria para então permear toda a comunicação empresarial. Para tanto, é fundamental que o posicionamento reflita a essência da marca, seja coerente com a qualidade e a promessa da mercadoria e se diferencie da sua concorrência, procurando passar a uma imagem sedutora, pertinente, coerente e crível. Tal processo envolve, portanto, um profundo conhecimento do público receptor, do contexto social, da concorrência, do mercado, da empresa e da mercadoria.

É responsabilidade do gerente da marca elaborar o seu posicionamento como parte integrante do briefing para a agência de propaganda e a esta cabe elaborar uma comunicação fundamentada nesse posicionamento, refletindo a essência da marca.

Portanto, o sucesso da marca está diretamente ligado ao seu posicionamento. Para sua elaboração o presente trabalho propõe utilizar uma metodologia baseada na semiótica greimasiana de Algirdas Greimas, o qual desenvolveu uma teoria semiótica voltada para o processo de significação e de construção de sentido.

Posicionar é exatamente isso, construir sobre um conceito fundamental, sobre a essência da marca um discurso que vai orientar a criação publicitária a desenvolver uma campanha, um discurso, que vai contribuir com a construção da imagem de sucesso para a marca.

Porém, o que se percebe na prática e nos principais livros sobre marketing e gerenciamento de marca - branding, é que os autores não se preocupam em ilustrar uma metodologia para a elaboração do posicionamento de marca. Outra questão diz respeito ao senso comum de marketing, o qual, uma vez posicionada uma marca, ou seja, uma vez escolhido um slogan e um caminho criativo de uma comunicação mercadológica, deve ser mantido por muito tempo com a finalidade de criar uma consistência da comunicação. 
Os consumidores procuram mercadorias para dar significado a suas vidas, para compor sua identidade na sociedade de consumo e comunicar a seus grupos e a si mesmo suas personalidades. Eles se baseiam nos valores que circulam na cultura de consumo. Ocorre que, ultimamente, esses valores têm se re-significado de forma muito rápida. Os significados não têm tempo suficiente para se solidificar na mente das pessoas, pois sofrem alterações constantes, fruto de uma dinâmica veloz da cultura de consumo globalizada e interconectada pelas novas tecnologias de comunicação em rede.

Desse modo, duas são as propostas deste estudo. A primeira é procurar estabelecer uma metodologia para elaboração do discurso para um posicionamento de marca, já trabalhada na dissertação de mestrado deste pesquisador. A segunda, e a mais importante, é reconhecer que há uma tensão entre a manutenção de uma posição, um conceito sobre a marca na mente do consumidor, e a sua flexibilização, acompanhando a dinâmica dos valores e dos significados dentro do contexto social. E que, por conseqüência disso, o posicionamento de marca deve ser revisto e, se necessário, modificado, tornando-o dinâmico também.

Assim sendo, a hipótese, nesta pesquisa, é a de que o posicionamento de marcas no mercado deve ser dinâmico, ou seja, deve acompanhar as rápidas e constantes movimentações dos valores e dos significados na vida do consumidor contemporâneo.

Deve-se ressaltar aqui que essa mudança de posicionamento freqüentemente acontece no mercado, mas ela ocorre de tempos em tempos, acompanhando o ciclo de vida da mercadoria, e raramente as mudanças dos significados aportados em sua comunicação mercadológica.

Para a verificação de tal hipótese procedeu-se a analise da comunicação do automóvel Ford EcoSport, estabelecendo qual foi o seu posicionamento, desde seu lançamento até hoje, e se houve alguma variação na forma ou no conteúdo deste, uma vez que, no período em questão, esse automóvel apresentou um volume de vendas constante e acima de seus concorrentes.

A metodologia utilizada para verificar se houve ou não flexibilização do posicionamento da marca EcoSport foi a análise semiótica das peças publicitárias impressas nas principais revistas brasileiras, procurando identificar, por meio do 
método do caminho de geração de significado, qual foi o posicionamento adotado em cada campanha.

A escolha do automóvel como mercadoria a ser estudada deveu-se ao fato de que este reúne uma grande variedade de significados que vão muito além das suas funcionalidades, além de ser uma mercadoria considerada durável e, por conseqüência, passível de uma análise ao longo do tempo.

Por outro lado, este trabalho também procurou entender, sob uma perspectiva histórica, a evolução dos significados automóvel como um signo e qual a relação deste signo com a cultura contemporânea, bem como o funcionamento do seu sistema de valorização de consumo. 


\section{POSICIONAMENTO SEMIÓTICA DE MARCAS}

O posicionamento pode ser considerado como a parte estratégica mais importante da administração de marketing, principalmente no que tange ao direcionamento de todo o esforço de comunicação, pois é exatamente através deste processo que se faz a conexão entre a marca e o seu público. Posicionar uma marca é colocá-la, por meio da comunicação das suas propriedades de identificação como o nome, o logo, o slogan, a embalagem, etc. -, numa posição de valor na mente do consumidor, diferenciando-a das suas concorrentes.

Para tal, é necessário selecionar um conceito a fim de identificar a marca, funcional e emocionalmente; um adjetivo para qualificá-la e diferenciá-la, que seja pertinente às funcionalidades da sua mercadoria, coerente com o discurso da empresa e que transmita significados desejados e compartilhados pelo público, enfim, um benefício para o consumidor. Este conceito deve permear toda a estratégia de concepção e fabricação da mercadoria, terminando na sua comunicação mercadológica.

Este capítulo pretende expor algumas práticas para o gerenciamento de marca e elaboração do posicionamento, culminando na pertinência do uso da ferramenta semiótica para o processo de posicionamento de marcas. 


\subsection{Sistema da marca.}

A marca comercial hoje é um ativo muito valioso. Só como um exemplo, segundo a pesquisa da Interbrand para a America Latina, a Natura vale $R \$ 1,879$ Milhões e está posicionada em décima quarta colocação. (INTERBRAND, 2008)

Considerando a pesquisa global da Interbrand, a coca-cola é a marca mais valiosa, avaliada em US\$66, 667 Milhões. Abaixo segue o ranking mundial das dez marcas mais valiosas no estudo para 2008:

MARCA VALOR em milhões de dólares

\begin{tabular}{|c|c|}
\hline 1․ COCA-COLA & 66 \\
\hline $2^{\circ}$. IBM & 59 \\
\hline 3․ MICROSOFT & 59 \\
\hline $4^{\circ} . \mathrm{GE}$ & 53 \\
\hline $5 \%$ NOKIA & 36 \\
\hline 6․ TOYOTA & 34 \\
\hline $7^{\circ}$. INTEL & 31 \\
\hline $8^{\circ}$. MCDONALDS & 31 \\
\hline 9․ DISNEY & 29 \\
\hline 10․ GOOGLE & 25 \\
\hline
\end{tabular}

Fonte: http://www.interbrand.com/best_global_brands.aspx?year=2002\&langid=1000

É interessante ainda notar a marca Google, sítio na Internet para buscas, aparecendo na décima colocação, desbancando marcas centenárias como a Ford e a Mercedes-Benz, por exemplo, que até 2001 figuravam entre as dez mais.

Considerando-se a importância da marca para a empresa e seu potencial de agregar valor, o seu gerenciamento é tarefa essencial na administração. Para se obter uma posição forte perante o público de determinada marca é necessário saber coordenar os principais fatores que influenciam o seu patrimônio da marca, tradução livre do termo brand equity. (AAKER, 1998: 18) São eles: 
- Lealdade à marca

- Conhecimento do nome

- Qualidade percebida

- Associações da marca

- Outros ativos da empresa

Entretanto, antes de se aprofundar nos conceitos relativos ao gerenciamento de marcas se faz necessário revisitar a própria definição do que é uma marca. Entre os acadêmicos da administração e os principais livros de Marketing a definição mais aceita é a da AMA - American Marketing Assotiation, que a define como "um nome, termo, sinal, símbolo ou design, ou uma combinação de tudo isso, destinado a identificar os produtos ou serviços de um fornecedor ou grupo de fornecedores para diferenciá-los dos outros concorrentes" (KOTLER, 2006: 269)

Um nome para identificar uma coisa, para mostrar que, embora existam outras dessas coisas semelhantes, esta tem um nome e um sobrenome e, portanto, é diferente das demais, porque possui um DNA diferente, tem uma origem própria, que conta sua história - gerando simpatia ou não -, para quem com ela entra em contato.

Para aceitar esta definição é necessário expandir o conceito da palavra identificar no sentindo de dar a certa coisa um conjunto de características próprias, como um nome, logotipo, embalagem, características funcionais diferenciadas, qualidade, etc., as quais seriam consideradas exclusivas desta, com a finalidade de torná-la mais atraente que outras coisas similares.

Mas ainda assim, como definição de marca, abarcando todas as suas propriedades, esta da AMA carece de complementos.

Uma marca, para existir de fato, precisa ser reconhecida pelo mercado. Seu nome, logotipo, cores, sons, etc., devem estar recheados de significados provenientes do mundo cultural, da percepção e da experiência de seus consumidores.

Uma marca passa a existir quando se é possível contar uma história a seu respeito, sendo que quatro tipos de "autores" estão envolvidos nesta tarefa: "as 
empresas, as indústrias culturais, os intermediários (como críticos e varejistas) e os consumidores (principalmente quando formam comunidades)" (HOLT, 2005: 19)

Toda esta carga perceptual dá a marca uma condição de signo, para o qual se convenciona uma gama de significados que vão conectar a empresa e sua mercadoria ao público, com seus desejos e aspirações. "A marca é uma conexão simbólica e afetiva estabelecida entre uma organização, sua oferta material, intangível e aspiracional e as pessoas para as quais se destina." (PEREZ, 2004: 10)

A marca, enquanto signo, está no lugar de algo, que engloba a mercadoria, com suas características funcionais, emocionais e sua própria história ou mitologia; a empresa, com toda a sua reputação; os seus símbolos (nome, logotipo etc.), com traços que remetam a possíveis associações com significados culturais preexistentes e, por fim, todo o estoque perceptual presente na mente do consumidor, resultado de experiências próprias ou de outros e do discurso publicitário da empresa.

As mercadorias, como objetos tangíveis ou intangíveis no caso dos serviços, possuem duas dimensões para o consumidor, uma baseada na sua utilidade e a outra como resultado das associações de ordem psíquicas alimentadas pelo discurso publicitário e do mundo cultural. A primeira é composta de valores funcionais e a segunda de valores de base (FLOCH, 1993)

São principalmente os valores de base, relativos às aspirações, emoções e desejos que são estimulados pelo discurso publicitário e direcionados para os signos da marca. Obviamente esse discurso deve ser crível com relação à qualidade funcional da mercadoria, pois em caso contrário o apelo emocional não se sustenta.

Com base na análise feita nos parágrafos anteriores, pode-se dizer que a marca comercial é uma criação da empresa com o objetivo de identificar e proteger seu produto, mas também sintetiza na mente do consumidor os discursos de origem racional e emocional que vão definir o grau de relacionamento que este consumidor quer ter com a marca e sua mercadoria.

Retomando a função de gerenciamento da marca, esta definição, bem como todas as outras, ressalta necessidade de se gerenciar a relação entre a identidade e a imagem da marca. Ou seja, fazer com que o discurso produzido pela empresa seja percebido e interpretado pelo público receptor de forma a criar significados positivos 
em suas mentes, valorizando a marca, tornando-a uma representação daquilo a que ele aspira para personalizar sua própria identidade.

No conceito de marca ilustrado por Ellwood, esta é vista como tendo um núcleo duro, mais perene, que representa a mercadoria e as experiências dos consumidores, e uma aura flexível, envolvendo o núcleo, que representa os significados compartilhados entre o produtor e o consumidor. (ELLWOOD, 2004)

No mesmo texto, Ellwood sugere que a parte perene, a mercadoria, seja o caráter e a aura a personalidade da marca. Essa metáfora humana parece ser muito apropriada. No nascimento de um bebe, damos-lhe um nome, que já diz algo sobre o sexo da criança e algumas associações com outras pessoas que tem ou tiveram o mesmo nome, e um sobrenome, que traz toda a herança da família para aquele novo ser.

Em seguida o bebe cresce e começa a se relacionar com o mundo. Em várias situações essa pessoa vai mostrar sua personalidade e causar sua impressão nas outras. Quem tiver um relacionamento com ele vai conhecer seus valores, suas crenças, seu caráter e entender melhor sua forma de agir.

Com uma marca não é diferente. De acordo com que foi visto até agora, esta é um sistema vivo. Contém um corpo com qualidades e funcionalidades decisivas para a decisão de compra e uma aura envolvente e sedutora, que vai servir de modelo para seu público construir sua própria imagem e que se configura como o principal fator na escolha da marca. Nessa psicologia da marca, quanto mais relacionamentos e experiências positivas ela tiver mais será lembrada, e muitos vão querer com ela se envolver.

Outra forma de encarar o sistema da marca foi apontada por Semprini. Em seu modelo de mercado da marca - sistema da produção, o autor distingue três pólos: o sistema da fabricação, que contém e distribui a mercadoria em si; o sistema da comunicação, que elabora e distribui o discurso publicitário e, interagindo com o sistema da fabricação e de comunicação, o público receptor, que, por sua vez, interage com ambos os sistemas, interpretando e consumindo mercadoria e discurso. (SEMPRINI, 1993) 
O quadro abaixo ilustra o que Semprini chamou de mercado da marca, uma interação entre a mercadoria, a comunicação e o público receptor (SEMPRINI, 1993: 49)

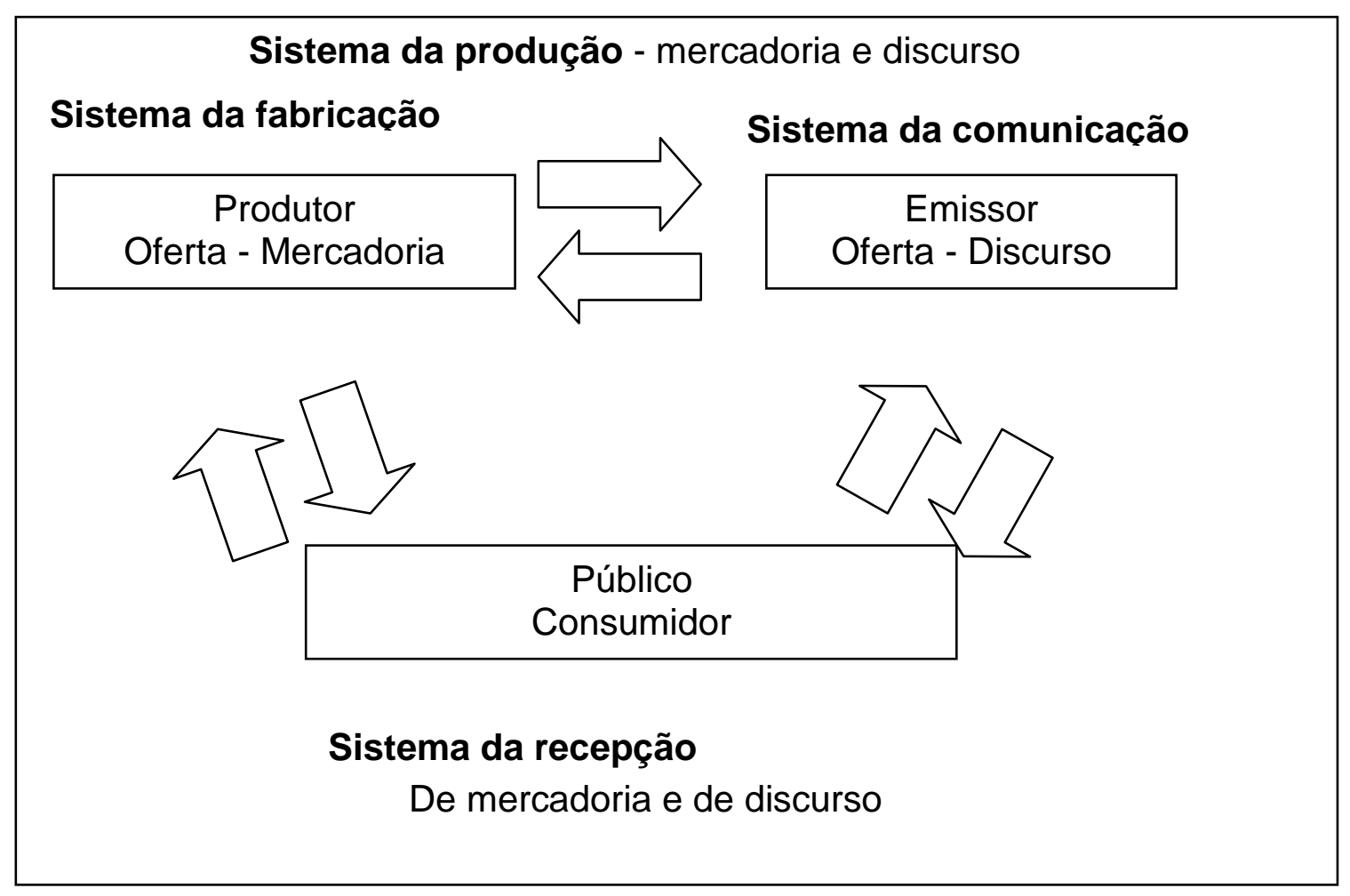

Quadro 1 - O mercado da marca

Enquanto o sistema de fabricação provê o objeto físico, o sistema da comunicação provê ao mercado uma existência imaterial e discursiva, dando à mercadoria um sentido, uma personalidade.

A interpretação da mensagem de discurso se dá na mente do consumidor, que interage com ela em função de seu nível de conhecimento sobre a mercadoria e de seus valores. Vale ressaltar que Semprini sugere adotar o termo consumidor somente para destacar o fluxo material da mercadoria, sendo que para o sistema completo o termo mais apropriado seria de ricettore, "receptor", quando se fala de um indivíduo, e de pubblico, "público" para o fenômeno de recepção coletiva. Estes termos dão conta da mercadoria-objeto e da mercadoria-discurso (SEMPRINI, 1993: $51)$. 
O consumo de marcas é uma ação comunicativa, pois o consumidor utiliza-a como uma linguagem para se apropriar de seus significados e comunicá-los no seu ambiente social, proporcionando-o uma sensação de pertencer, de ter um estilo de vida, de ser respeitado e admirado. Por isso, é de capital importância para o sucesso da marca que o seu discurso, a promessa da marca, seja crível e coerente com a qualidade da mercadoria e a reputação da empresa.

Para dar conta desse alinhamento estratégico, três conceitos devem ser destacados: Missão, identidade e imagem da marca.

\section{Missão da marca}

Toda empresa ou organização tem, ou deveria de ter, um norte, uma visão estratégica direcionando suas ações. Para atingir esse objetivo, as empresas estabelecem uma missão, que seria a forma de se chegar à visão. Se a visão é o norte, a missão são os trilhos por onde a empresa deverá caminhar.

Em geral, a missão é um enunciado que reflete aonde a empresa quer chegar, como ela pretende chegar e quais os valores que sustentam essa intenção. O importante aqui é entender que há sempre um grande objetivo a ser perseguido. Ser líder de mercado, ou estar sempre na vanguarda da tecnologia. Por sua vez, tal objetivo vai se desdobrar para outros departamentos da empresa, gerando objetivos e metas funcionais para cada um deles.

Assim, como exemplo, a produção deverá traçar seu plano, bem como a engenharia e o marketing. Todos devem estar nos trilhos rumo ao norte. Essa coerência é fundamental para um discurso empresarial. Não importa o meio. Pode ser o design do produto, a forma como este se apresenta no ponto de venda, a campanha publicitária, pode ser o perfil dos seus vendedores, enfim, todo o ponto de contato com o mercado deve ter uma única essência comunicativa.

Essa essência deve permear a marca-mãe e todas as suas marcas independentes, se houver. Como esclarecimento, é bom lembrar que existem empresas com arquitetura de marca de cobertura, ou seja, uma marca-mãe com vários produtos levando seu nome, outras com arquitetura diferenciada, nas quais a empresa não expõe seu nome (em alguns casos sim) criando marcas independentes, ou seja, cada produto, de diversos ramos, tem sua própria marca. 
Entre esses dois extremos existem alguns formatos mistos, como uma empresa com sub-marcas, produtos de um mesmo ramo, mas com nomes diferentes e marcas endossadas, produtos de diferentes ramos com marcas diferentes, caso em que uma marca reconhecida empresta sua imagem a outra não tão conhecida, como, por exemplo, Hotel Madero by Sofitel, sendo que, no caso, a marca "Sofitel" chancela a marca "Madero".

Se do lado da organização a missão indica como alcançar seus objetivos, do lado do público há a necessidade de oferecer um benefício que seja valorizado. No caso da empresa com arquitetura de cobertura, o benefício deve ser abrangente, onde cada produto deve sempre falar do mesmo. Quando a empresa tem uma arquitetura de marcas diferenciadas, a missão da empresa deve permear todos os produtos, porém cada um deles deve deixar bem claro qual é o benefício que traz para o seu público. (LENCASTRE, 2005)

A missão da empresa deve conter um benefício que se transfere para a missão da marca. É esta que vai até o público e dá significado à empresa por meio da mercadoria e da comunicação. Portanto, a missão é uma declaração, que deve ser encarada como um contrato para o seu público sobre o benefício oferecido. A comunicação, nesse entendimento, deixa de ser somente uma parte do mix de marketing para ser uma distribuidora do significado da identidade da marca.

Cabe ilustrar aqui que muitas empresas ainda consideram que uma grande estratégia publicitária vai conduzi-las ao sucesso. Ao entender melhor o mercado da marca, fica claro que isso somente não basta. Todo o composto de marketing deve proporcionar uma mercadoria valorizada pelo consumidor. Uma personalidade de marca forte, por si só, não é suficiente: faz-se necessário também entregar o caráter da empresa.

Com o decorrer do tempo de relacionamento com o cliente, este tenderá a não confiar na marca, caso a personalidade desta (isto é, as características emocionais e humanas associadas a uma marca por meio da publicidade, como: viril, forte, sensual, provocante) não corresponda ao caráter de sua empresa, ou seja, aquilo que realmente se entrega em termos de qualidade, ponto de venda, preço, políticas externas de meio ambiente e cidadania e política de recursos humanos. 
Nesse sentido, para uma marca obter sucesso é necessária uma consistência entre suas estratégias empresariais e seus discursos, entre seus objetivos e os benefícios funcionais e emocionais oferecidos ao publico. Enfim, uma consistência entre a identidade e a imagem da marca.

Identidade e imagem da marca

A identidade da marca é o conjunto exclusivo de todas as associações desejadas pela empresa para a sua marca. É o que a empresa pretende que a marca signifique para seu público.

Para construir esse significado é necessário analisar inicialmente o público, a concorrência e a própria empresa, sendo:

Público: desejos, motivações, tendências e tamanho do segmento.

Concorrência: missão, produto, arquitetura, público e imagem vs. identidade.

Empresa (auto-análise): imagem vs. identidade - onde estou, para onde quero ir.

Dessa análise deve-se obter um conceito valorizado pelo público, diferente dos da concorrência e que sirva de inspiração para nortear toda a estratégia empresarial. A identidade da marca deve estar coerente com a missão da empresa.

Definida uma identidade para a marca, alinhada com os valores da empresa, com os atributos do produto e diferenciada da concorrência, faz-se necessário materializar esse escopo, dando-lhe forma. Os elementos que compõem essa formalização são: nome, logo, slogan, jingle, enfim os signos que se colocam no lugar da empresa e dos seus produtos com a função de conectar os valores funcionais e emocionais atribuídos aos produtos, como as funcionalidade e desejos do público. Esses elementos de identidade da marca são, na verdade, seus signos com um significado almejado pela empresa e a ser passado para o seu público.

Cabe aqui ressaltar alguns aspectos da identidade da marca. Em primeiro lugar, a questão da diferenciação. Qualidade, preço e desempenho funcional estão cada vez mais equânimes entre concorrentes e, portanto, cada vez mais imperceptíveis para o consumidor. O que faz uma marca diferenciar-se é a forma 
com que ela se relaciona com seu público, é o componente emocional transmitido pela comunicação mercadológica e a experiência do consumidor com a marca.

Um segundo ponto é referente ao nome e logo. Especificamente para quem está buscando um nome para uma nova marca. O nome é a primeira impressão, deve realmente tentar dizer algo sobre a identidade da marca. Nomes indecifráveis, siglas e nomes próprios necessitam de um grande investimento de tempo e dinheiro, recursos, em geral escassos nos dias de hoje. Faz-se necessário também olhar o todo e encaixá-lo na arquitetura de marcas da empresa. Quanto ao logo, ele é o nome visual, e que impacta rapidamente na mente. Deve ser testado com muito cuidado, pois evoca no público associações que podem contribuir ou destruir.

Como terceiro ponto temos o slogan, que provém de um enunciado de posicionamento que deve ser consistente e crível. Ele deve explicitar o benefício, a missão da marca de forma clara, porém, a mais sintética possível, para poder ser repetido facilmente e, conseqüentemente, lembrado. A sua repetição vai gerar o conhecimento da marca. A consistência de um benefício realmente entregue ao público vai gerar uma experiência positiva com a marca, aumentando sua confiabilidade e seu valor.

Enquanto a identidade da marca é o significado buscado pela empresa, a imagem é o significado percebido na mente do público, resultante da experiência com a marca e da comunicação.

A imagem é a "leitura" dos signos da marca feita pelo interpretante, fechando a semiose que se iniciou na empresa, na estratégia, no mix de marketing. É a interpretação da oferta funcional e emocional que foi simbolizada pelo mix de identidade (LENCASTRE, 2005). A imagem, como conseqüência de todo esforço da empresa, é o fiel da balança em termos de valor da marca. Portanto é fundamental para o gestor de marca obter uma identidade bem construída para resultar em uma imagem positiva e forte.

Entre a identidade e a imagem da marca estão todas as associações possíveis para conectar esta última, sua mercadoria tangível e sua personalidade aspiracional, ao seu público. Cabe ao gestor da marca escolher um caminho pelo qual os discursos vão fluir com coerência para formar a melhor imagem possível. Ele deve considerar os atributos do sistema da produção, o contexto social, cultural, 
político, econômico e de mercado (incluindo a concorrência) e o sistema de valorização do consumo do público receptor para escolher um conceito, extraído do conjunto que forma a identidade da marca, para ser o vetor de significação de toda a sua comunicação.

Esse processo de escolha e significação para a elaboração da estratégia de comunicação da marca constitui o posicionamento de marca. 


\subsection{Posicionamento de marca}

Posicionar, no universo do marketing estratégico, significa estabelecer um processo para comunicar o principal benefício de uma marca e colocá-la em uma determinada posição de distinção na mente do público, frente aos seus concorrentes. $O$ termo nasceu da necessidade cada vez maior de as marcas serem diferentes para conseguirem chamar a atenção, obterem a consideração e serem desejadas pelo seu consumidor.

Já há algumas décadas a proliferação de produtos, marcas e categorias, aliadas ao excesso de comunicação, sobre tudo isso, vêm inundando os sentidos das pessoas, o que, por sua vez, como uma forma de defesa, vem deixando sua percepção cada vez mais seletiva. Para chamar a atenção e conseguir vantagens competitivas sobre seus concorrentes ao longo do tempo, as marcas optaram por uma estratégia de diferenciação.

Esta pode ser conseguida através de uma tecnologia inovadora, uma funcionalidade exclusiva, uma qualidade insuperável, ou outros atributos inerentes a mercadoria. Tais diferenças, embora reais, podem não ser duradouras, pois as técnicas hoje em dia são mais acessíveis, possibilitando aos concorrentes copiar ou desenvolver itens para se igualarem com a marca vanguardista.

A boa reputação da empresa, seu histórico de conquistas e suas boas relações com a comunidade, fornecedores, funcionários e com seu público, também contribuem para uma diferenciação valorizada e, dependendo do grau e da sinceridade destas relações, dificilmente serão "copiadas" pela concorrência.

A qualidade da mercadoria e a reputação da empresa são atributos importantes na construção de uma imagem diferenciada na mente do público. Elas são, na verdade, imprescindíveis, mas não o suficiente para se construir uma identidade completa para a marca que seja distinta de outras concorrentes $\mathrm{O}$ consumidor espera de uma marca um modelo de vida, um conjunto de significados para uma construção psíquica de suas próprias identidades, um estilo de vida, que na maioria dos casos é somente aspiracional.

Então, para uma marca obter uma posição diferenciada na mente do consumidor ela deve se destacar em duas dimensões: a primeira formada pelas qualidades da mercadoria, e uma segunda formada por uma "aura flexível" 
(ELLWOOD, 2004: 19), que engloba a reputação da empresa e os significados gerados pela comunicação mercadológica.

Como visto anteriormente, Ellwood chama o sistema de características físicas e funcionais e a qualidades da mercadoria de caráter, e o sistema dos significados compartilhados com o público de personalidade da marca (ELLWOOD, 2004). Semprini, por sua vez, considera essa mesma interação entre estes dois sistemas e o público, porém enfatiza o papel do consumidor como receptor do sistema de produção do produto e do discurso, interagindo na interpretação do mercado da marca como um texto. (SEMPRINI, 1993: 49)

Um caráter forte é fundamental para gerar boas experiências e conseqüente continuidade no uso da marca, mas é a personalidade sedutora e flexível, que se molda às mudanças do mundo cultural, que atrai o consumidor com a promessa de satisfazer seus desejos e projetar sua identidade, seu estilo dentro de sua comunidade. O posicionamento de marca trabalha para comunicar a personalidade da marca, amparada no seu caráter, em toda a comunicação, de forma que o público receptor faça uma leitura mais próxima possível da intenção da empresa.

\section{Processo de posicionamento.}

Verificou-se, após pesquisa bibliográfica, que poucos autores foram além da definição e recomendação do posicionamento de marcas, orientado quanto ao processo ou metodologia para sua elaboração. Em sua grande maioria, os autores ressaltam as origens do posicionamento, seu conceito e sua importância estratégica para a comunicação da empresa, porém pouco se fala sobre uma metodologia para sua construção.

David Aaker em seu artigo de 1989, Positioning your product identificou seis etapas no processo de posicionamento: (AAKER, 1989)

- Identificação dos concorrentes;

- Verificação de como a concorrência é percebida ou avaliada;

- Determinação da posição da concorrência;

- Análise dos clientes; 
- Seleção da posição;

- Monitoramento da posição.

Os passos e sua seqüência parecem adequados, porém o que continua obscuro é como mapear a posição da concorrência e como selecionar uma posição para a marca estudada, enfim, qual o conceito fundamental e como construir um enunciado partindo dele.

Kotler e Keller apresentam também um processo baseado nos pontos de paridade e nos pontos de diferenças, como segue (KOTLER, 2006: 307)

- Definição do mercado-alvo e o tipo de público;

- Estabelecer os pontos de paridade com a concorrência, que compreendem as associações necessárias para o público entender a qual categoria a marca pertence ou quais são seus concorrentes diretos.

- Qual o produto;

- Qual a sua função;

- Quais os benefícios da categoria;

- Comparar com produtos exemplares;

- Contar com um nome, logotipo e embalagem adequada à mercadoria.

- Estabelecer os pontos de diferenciação com a concorrência, levando em consideração os pontos de paridade, estabelecendo diferenças desejáveis. Para as diferenças serem desejáveis, devem seguir três critérios, sendo eles: relevância; distintividade e credibilidade. Os pontos de diferenças podem estar nos seguintes itens:

- Produto

- Estilo e design;

- Desempenho e durabilidade;

- Confiabilidade;

- Qualidade superior. 
○ Serviço

- Atendimento;

- Comodidade para o cliente;

- Treinamento para o cliente;

- Consultoria ao cliente;

- Assistência técnica

- Qualidade superior.

- Funcionários

- Habilidade e conhecimento;

- Gentileza;

- Credibilidade;

- Presteza.

- Canal

- Cobertura geográfica

- Especialidade;

- Desempenho.

○ Imagem

- Estabelecer a personalidade da marca;

- Comunicar essa personalidade.

Com relação a esta metodologia, parece mais completa sob o ponto de vista das funcionalidades da mercadoria, mas como estabelecer paridades e diferenças relativas à imagem da marca e de seus concorrentes? Como estabelecer a personalidade da marca e preparar um briefing para a agência de propaganda comunicá-la?

O que se conclui é que, para posicionar uma marca, é necessário compará-la com os principais concorrentes dentro de uma categoria, ou lançá-la em uma nova para "ensinar" ao público que tipo de mercadoria está sendo ofertado. Esta 
comparação deve levar em consideração os atributos funcionais e de base, ou seja, comparar o caráter e a personalidade da marca, suas funcionalidades e os significados que podem ser compartilhados com o público.

A proposta aqui é utilizar a ferramenta semiótica desenvolvida por Greimas, aplicada ao marketing por Floch e adaptada ao mapeamento de marca por Semprini para posicionar marcas. Esta metodologia permite, por meio da comparação das possibilidades de significação entre os sistemas da produção de mercadoria e do discurso e o mundo cultural, encontrar a essência da identidade da marca, possível de ser interpretada e valorizada na mente do público receptor, resultando em uma imagem de marca forte, colocada em destaque na preferência de compra.

Neste sentido, será apresentada a seguir uma breve exposição da teoria semiótica de Greimas e os princípios da metodologia de posicionamento na utilização desta ferramenta. 


\subsection{Semiótica e o posicionamento de marca}

Nós primórdios da existência humana, o homem já nomeava coisa, animais e seus semelhantes. A substituição do objeto por algo que o represente é uma operação natural e, portanto, ocorre sem que se dê conta disso. Tudo que pode representar algo é chamado de signo; pode ser uma palavra, um desenho, uma fotografia, um gesto, etc. Embora natural, esse processo de atribuir um significado às coisas não é uma ato individual, depende do contexto social e cultural. Também não é estático, está sempre num ciclo dinâmico de significação. Ao campo de estudo que investiga os signos e suas significações dá-se o nome de semiótica.

A semiótica estuda a ação dos signos, ou "semiose", (PEREZ, 2004: 140) e os processos de significação dentro de um contexto cultural. Ela verifica as relações entre o referente, o signo e os significados atribuídos. Winfried Nöth definiu a semiótica como "a ciência dos signos e dos processos significativos na natureza e na cultura" (NÖTH, 1995: 17).

O signo é o elemento básico para a semiótica, ele é tudo aquilo que representa algo para alguém. Exemplificando: a palavra copo substitui o próprio objeto, assim como o desenho de um copo também o faz. Seguindo a concepção do lingüista suíço, Ferdinand Saussure, a idéia de signo pode ser visualizada como a relação entre as duas faces de uma mesma folha de papel, de um lado a face provida da forma, a palavra copo, e do outro a que possui o conteúdo, a imagem acústica deste.

Para forma e conteúdo Saussure utilizou os termos, significante e significado. Hjelmslev, por sua vez, adotou os termos, plano de expressão e plano de conteúdo. A relação entre estes dois planos chama-se significação. (NÖTH, 1999) Outra forma de se definir signo é considerar o objeto como uma terceira dimensão. Assim, o signo triádico é composto de signo, objeto e a cognição produzida na mente, ou interpretante.

A concepção triádica do signo foi fator primordial para o norte-americano Charles Sanders Peirce, que o definiu como algo que intenta representar, em parte pelo menos, um objeto que é, portanto, num certo sentido, a causa ou determinante do signo, mesmo se o signo representar seu objeto falsamente. (SANTAELLA 1983) 
Três são as principais correntes da semiótica moderna: semiótica peirceana, semiótica greimasiana e semiótica da cultura, de origem russa. (PEREZ, 2004: 140) Este trabalho, como já dito acima, se concentrará na semiótica greimasiana.

\section{O projeto semiótico de Greimas}

Algirdas Julien Greimas, nascido em nove de março de 1917, em Tula, na Lituânia e morto em 1992 em Paris, foi um lingüístico que contribuiu para o desenvolvimento da teoria semiótica de origem francesa, iniciada por Saussure. As bases para o pensamento de Greimas foram: a estrutura de oposições e diferenças binárias para se chegar a um significado, o estruturalismo lingüístico de Hjelmslev, a teoria formalista do conto de Vladimir Propp, a antropologia estrutural de LevyStrauss e a teoria das situações dramáticas de Etienne Sourian.

Greimas elaborou uma semiótica narrativa, uma metodologia que permite analisar a organização dos discursos, em um plano de conteúdo, a partir do conceito de narratividade, apoiada na premissa de que a estrutura narrativa se manifesta em qualquer tipo de texto. Inspirado nos estudos de Propp, Greimas identificou a existência de formas universais de organização da narrativa de um texto.

Essas formas repetem-se nos mais diversos textos, permitindo perceber as estruturas que sustentam a construção do sentido e da significação destes. Para a análise dos textos aplicam-se métodos da pesquisa lingüística estrutural; desse modo, os esquemas narrativos desenvolvem-se através de relações paradigmáticas e sintagmáticas.

A construção da significação na semiótica greimasiana é um conceito-chave. Ela é obtida através de um caminho de geração de sentido, que parte de uma relação elementar constituída pela diferença entre dois termos semânticos. Dessa oposição nasce o eixo semântico, onde esses termos são confrontados na busca de uma unidade semântica mínima, com a função de diferenciar o significado, o que Greimas chamava de sema. Partindo desse eixo é construído o quadrado semiótico, no qual os termos opostos numa relação de contrariedade ganham pares contraditórios, formando três tipos de relação de sentido: relação de contrariedade entre os termos do eixo semântico, como, por exemplo, bem e mal; relação de 
contradição entre estes termos e suas negações: não bem e não mal; e a relação de complementaridade entre os termos contrários e contraditórios.

Esse caminho de geração de sentido pode ser trilhado não somente para entender como certo significado foi gerado, num estudo analítico, mas também para gerar, sobre um conceito básico, todo um "texto" coerente e coeso. Ressalte-se aqui que o termo "texto", empregado neste trabalho, não é somente o texto formado por palavras, mas todas as manifestações e formas significantes que podem transmitir um significado que pode ser "lido", entendido. Exemplo: a fotografia, uma obra de arte, uma dança, um comportamento, um gesto, etc. É nesse ponto que a semiótica greimasiana tem muito a oferecer às estratégias de marketing, contribuindo para o processo de posicionamento, a fim de se construir significados mais pertinentes e sedutores para marcas e suas mercadorias.

A obra deixada por Greimas (1917-1992) é extensa, complexa e bem elaborada. Qualquer tentativa de sumarizá-la pode incorrer no risco de ficar superficial demais ou de se estender além do necessário. Assim, para efeito deste trabalho, serão focados os pontos mais importantes de seu legado que estarão relacionados com a metodologia a ser apresentada nos capítulos seguintes.

Os principais aspectos da semiótica greimasiana são três; o estabelecimento das bases para os princípios da semântica, baseado no trabalho de Sausurre, Roman Jakobson e Louis Hjelmslev, no qual o grande destaque foi para a estrutura elementar de significação, ou quadrado semiótico; uma gramática narrativa, na tentativa de desenvolver uma análise sintática do discurso, e a modalização, um caminho de geração de significação partindo de uma estrutura profunda, abstrata e imutável, evoluindo até as estruturas de superfície, perceptíveis como formas significantes.

Para chegar à significação, Greimas construiu o caminho de geração de sentido, que se inicia nas relações de oposição do eixo semântico, na busca de uma significação abstrata elementar, até as manifestações concretas dos signos. Esse caminho é formado por estruturas sobrepostas em três níveis, indo do abstrato para o concreto: estrutura semio-narrativa profunda, estrutura semio-narrativa de superfície e estrutura discursiva. 
A figura II, a seguir, esquematiza o caminho de geração de significação de um texto através dessas estruturas. De forma resumida, será abordada cada uma de suas camadas, bem como os principais conceitos dessa semiótica instrumental, que pode ser aplicada a qualquer tipo de textos, seja lingüístico ou não, revelando-se uma importante ferramenta para se entender o sentido das mais variadas manifestações significantes.

Quadro II

\section{Significação de um texto (expressão e conteúdo)}

Estrutura Discursiva
Estrutura semio- narrativa superfície

Estrutura semionarrativa profunda (Quadrado Semiótico)

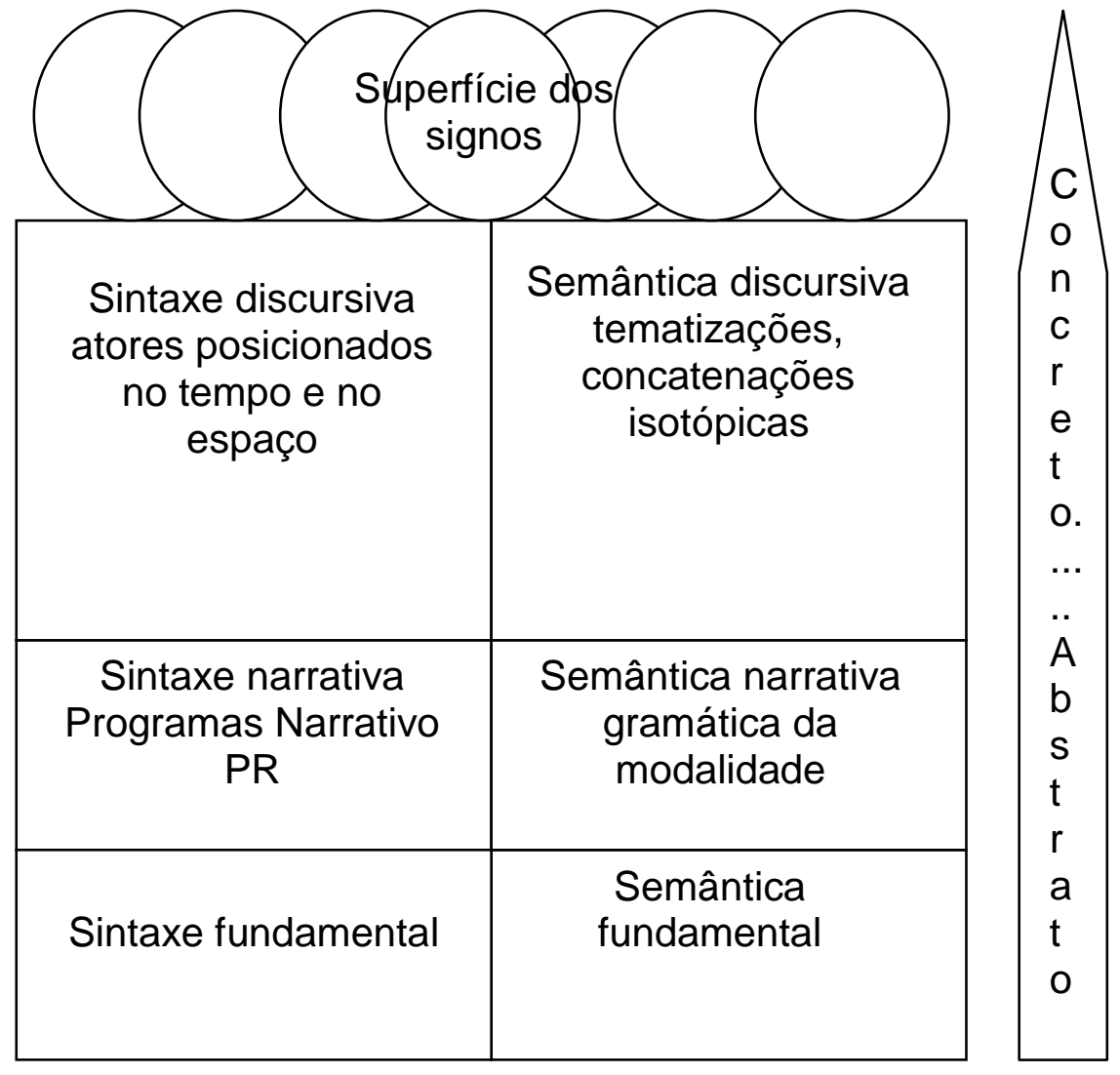

$\begin{array}{cc}\text { Componente } & \begin{array}{c}\text { Componente } \\ \text { sintático }\end{array} \\ \text { semântico }\end{array}$

\section{Estrutura semio-narrativa.}

O caminho de geração de significação se divide em duas vertentes, que são os componentes de toda a gramática: o componente semântico, que organiza posições e valores; e sintático, que organiza a lógica da sequêencia dos elementos 
do discurso. No início do seu percurso, a significação passa por estruturas semionarrativas e discursivas. As estruturas semio-narrativas são o conjunto das virtualidades que um sujeito que enuncia dispõe; é um estoque de valores e programa de ação de onde se podem extrair elementos para se compor um texto. (FLOCH, 1993)

As estruturas semio-narrativas se compõem de dois extratos: um profundo e outro mais superficial. No seu extrato profundo a vertente semântica chama-se fundamental. É um inventário de categorias sêmicas que podem ser exploradas pelo sujeito da enunciação. A vertente sintática, sintaxe fundamental, consiste de constelações actanciais básicas. (NÖTH 1996) Neste nível profundo, a significação se apresenta de forma abstrata, com estruturas elementares que podem ser formuladas como categorias semânticas, susceptíveis de serem articuladas no quadrado semiótico.

O quadrado semiótico é a "representação visual da articulação lógica de uma categoria semântica qualquer". (GREIMAS \& COURTES 1979: 364) Aqui se define a estrutura elementar de significação, na relação entre dois termos opostos num eixo semântico. Como exemplo, tome-se uma categoria de juízo: duas pessoas discutem acerca de se algo está bem ou mal, em que os conceitos pressupõem a existência um do outro, não se podendo definir o bem sem entender o mal. (FLOCH 1993) Assim, tal posição coloca estes dois elementos em uma relação qualitativa de contrariedade, conforme figura III abaixo:

Quadro III Eixo semântico

Bom

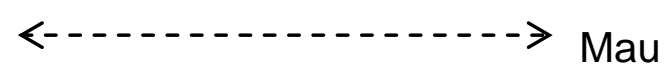

Relação de contrariedade

A discussão poderá evoluir, as pessoas poderão querer rever suas opiniões, acerca do que é bem e o que é mal, redefinindo suas posições acerca do julgamento, acrescentando novas opiniões como: "não está mal", quem antes dizia que estava "bem" e a outra, que dizia estar "mal", agora diz "não está bem". 
Percebe-se que estas novas opiniões se formam partindo de uma negação, aparecendo uma nova relação, a de contradição entre o bem e o não bem, que se estabelece a partir de uma negociação, pois a posição não está bem não significa que é de todo mal, e o mesmo serve para o não está mal em relação ao bem.

Quadro IV Relações de contrariedade e contradição

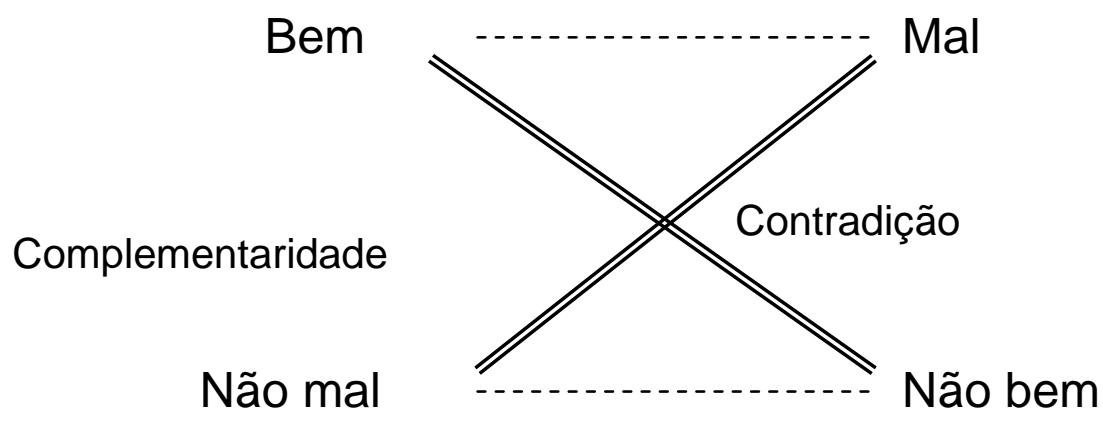

Contrariedade

A relação de contradição é definida pela impossibilidade dos dois termos, bem e não bem, de se apresentarem juntos, sendo assim uma relação estática. A relação de contrariedade, de uma forma dinâmica de negação, gera uma nova posição que contradiz a sua posição primitiva. Em conseqüência da contradição dos dois termos primitivos bem, gerando não bem, e mal, gerando não mal, obtém-se um quadrado formado por quatro posições definidas e inter-relacionadas por critérios de contrariedade e contradição.

Outra relação se apresenta nas laterais desse quadrado. Tomando um dos lados, a posição não mal, no exemplo da discussão entre duas pessoas, verifica-se que, afirmando que algo não está mal, implica que ele está bem. Esta operação é chamada em semiótica de asserção, e define, assim, a relação entre as posições não mal com bem e, as simétricas, não bem com mal como complementares.

Assim se constrói o quadrado semiótico com as operações de asserção e negação, e as relações de contrariedade, contradição e complementaridade. Vale dizer que o significado completo de qualquer uma dessas quatro posições (bem, 
mal, não bem e não mal) na superfície dos signos, vai ainda depender do caminho de geração de significação.

Quadro V Quadrado semiótico
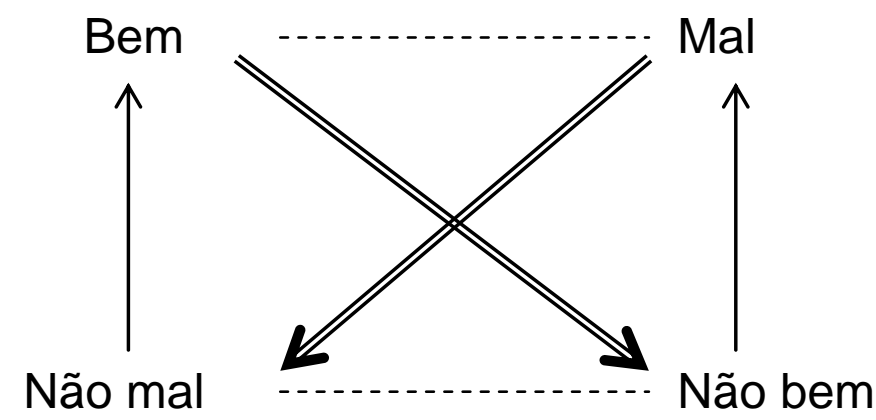

Contradição

Contrariedade

Complementaridade

A estrutura semio-narrativa de superfície no componente semântico apresenta a semântica narrativa, responsável pela atualização dos valores semânticos selecionados na fase precedente. Estes valores, por seu turno, dividem-se em descritivos e modais. Os descritivos podem ser essenciais ou acidentais. Os modais referem-se às categorias como "desejo", "obrigação" ou "conhecimento", elementos que formam a gramática das modalidades. (NÖTH, 1996)

No que tange ao componente sintático no nível da estrutura semio-narrativa de superfície, a sintaxe narrativa analisa a estrutura de sintagmas narrativos elementares, os chamados programas narrativos, e as categorias profundas 
aparecem nesta fase do caminho, como categorias antropomórficas, como ações de sujeitos humanos.

Nesta fase se estabelece uma relação-função entre pelo menos dois actantes (exemplo: sujeito - objeto), formando o enunciado narrativo elementar. Esta concepção de enunciado elementar é responsável pela conversão da sintaxe fundamental em sintaxe narrativa.

Os actantes são "seres" do discurso, e a organização destes e suas relações na narrativa estabelecem o "modelo actancial", que está estruturado com enunciados conjuntivos, quando há uma relação entre o sujeito e o objeto dotado de valor, que pode ser objetivo ou subjetivo. Quando o objeto de valor não está em conjunção com o sujeito, define-se como um enunciado disjuntivo, cuja relação está mantida na possibilidade de conjunção.

Além do sujeito e do objeto de desejo, existem outros seres do discurso, como o destinador e o destinatário, que formam um segundo par de actantes interligados pelo objeto de desejo. O destinador é aquele que, por saber fazer, pode transmitir um poder para um destinatário, que pode ser o sujeito (herói), para este conquistar o objeto desejado; neste caminho, outros seres, como os ajudantes e os opositores, entram em cena.

\section{Esquema narrativo}

O formalista russo Vladimir Propp, em sua obra "A morfologia do conto maravilhoso", analisou uma série de contos, procurando estabelecer uma estrutura comum que pudesse ser aplicada a de todas as narrativas. Classificando os personagens por suas funções no texto, e não por aquilo que são, Propp chegou a trinta e uma funções comuns aos contos analisados.

Com base nesse trabalho, a semiótica procurou estabelecer um modelo universal para organizar todas as narrativas. As funções de Propp constituem um inventário grande para se poder estruturar, assim se fez necessário "acasalar", termo utilizado pelo próprio russo (GREIMAS, 1976: 253), algumas funções. Houve então uma redução para vinte delas, o que, pelo numero, ainda não era suficientemente manejável. Greimas propôs então um procedimento comparativo, procurando 
identidades a "conjuntar" e oposições a "disjuntar", reduzindo as funções para três provas: "qualificante, decisiva e glorificante". (GREIMAS, 1979: 297)

A três provas apresentam regularidades dentro de um esquema sintagmático e paradigmático que permitem estabelecê-las como um sistema narrativo universal. Na prova qualificante o sujeito se torna competente, apto para realizar algo; na prova decisiva o sujeito se realiza levando a cabo certo numero de ações; por fim, na prova glorificante, o sujeito conquista o reconhecimento por aquilo que realizou.

Para a realização dessas provas surgem outros "seres" do discurso. Se há um sujeito que busca realizar algo, um objeto, pressupõe-se existir também uma confrontação com um anti-sujeito; o sujeito pode contar ainda com adjuvantes, por conseguinte, oponentes; um destinador providenciará o objeto para um destinatário.

Como exemplo de esquema narrativo pode-se analisar o currículo de certo candidato a um emprego. Suas responsabilidades e sua seriedade classificam-no como um bom sujeito, segundo um dever-fazer; Sua motivação e seu temperamento Ihe dão um querer-fazer; seus diplomas, sua experiência e competências técnicas Ihe dão um saber-fazer; sua disponibilidade, por fim, Ihe dão um poder-fazer.

O envio do currículo, em resposta a um anúncio de emprego, se estabelece como um contrato; o empregador coloca no anúncio uma série de requisitos necessários para o posto, e, através do envio do currículo, o candidato demonstra seu desejo de participar do processo. Devido às suas competências, o candidato é pré-selecionado, passando por uma prova qualificante, e está apto para fazer os testes. Segue-se então a realização dos testes, numa prova decisiva, na qual o candidato mostra o seu desempenho. Por fim, vem a sanção, a comparação dos resultados dos testes com o exigido no anuncio (contrato) e a contratação do candidato, reconhecido numa prova glorificante. 
Quadro VI - Esquema narrativo

\begin{tabular}{|c|c|c|c|}
\hline Contrato & Competência & Desempenho & Sanção \\
\hline 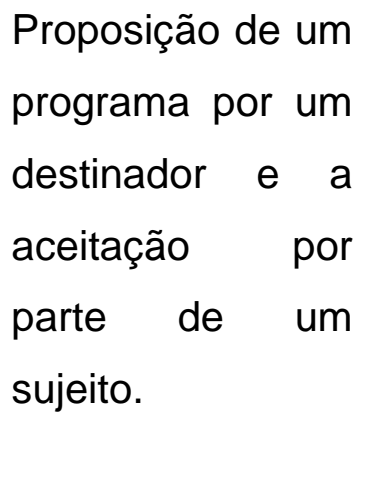 & $\begin{array}{l}\text { O sujeito adquire } \\
\text { amplitude para } \\
\text { realizar } \\
\text { programa - Prova } \\
\text { qualificante. }\end{array}$ & $\begin{array}{l}\text { Realização do } \\
\text { programa - Prova } \\
\text { decisiva. }\end{array}$ & $\begin{array}{l}\text { Comparação } \\
\text { entre o contratado } \\
\text { e o realizado - } \\
\text { Prova glorificante. } \\
\text { O reconhecimento } \\
\text { do sujeito pelo } \\
\text { destinador. }\end{array}$ \\
\hline
\end{tabular}

Fonte: FLOCH, 1993:79.

Importante ressaltar que o sujeito de um esquema narrativo pode ser individual ou coletivo: uma empresa, um gerente, uma comunidade, ou mesmo uma mercadoria, como um eletrodoméstico ou um automóvel.

\section{Sintaxe narrativa}

No esquema narrativo foi visto que existem duas relações fundamentais e, conseqüentemente, quatro actantes da narração: a primeira relação está entre o sujeito e o objeto, que é uma relação de intenção, de busca que cria a tensão necessária para o andamento do relato. A segunda é a relação entre o destinador e o destinatário, esta é uma relação de comunicação do objeto. Por outro lado, no decorrer das ações, encontram-se outra relação actancial relativa aos que ajudam ou que se opõem ao herói, que é a relação entre o ajudante e o oponente.

$\mathrm{Na}$ dinâmica das relações, o sujeito ou o anti-sujeito ganham ou perdem, fazendo o objeto de desejo circular de um lado a outro por meio de conjunções ou disjunções. A sintaxe da narrativa se serve então de um mínimo de categorias fundamentais:

a) Conjunção vs. Disjunção;

b) Sujeito de estado (disjunto ou conjunto) vs. Sujeito do fazer (sujeito que realiza o passo de um estado a outro)

O encadeamento de uma disjunção e uma conjunção - ou por outra, se o sujeito de estado e o sujeito do fazer são idênticos ou não, se o objeto pode estar 
conjunto com os dois sujeitos de estado ao mesmo tempo, ou se sua conjunção com um, provoca automaticamente a disjunção do outro - produzirá encadeamentos complexos.

Este mecanismo forma, através das categorias fundamentais, uma unidade narrativa mínima, uma espécie de unidade molecular do relato, que se chama programa narrativo. Por sua vez, uma sucessão de programas narrativos forma um caminho narrativo.

\section{Estrutura discursiva.}

A estrutura discursiva está identificada em uma camada acima da estrutura semio-narrativa, assim sendo, no caminho do abstrato para o concreto, esta fase encontra-se no limiar da relação de significação (expressão e conteúdo) já muito próximo da textualização. Neste nível, ocorrem os processos de figuração, temporalização, espacialização, sociabilidade etc.

Enquanto as estruturas semio-narrativas contêm os valores e os programas de ação, as estruturas discursivas correspondem à seleção e a disposição destes em certo universo de referência distribuídos no tempo e no espaço, atribuindo ao actantes seus papeis para entrarem em cena, transformando-os em atores do enunciado. 


\subsubsection{Posicionamento semiótico de marca}

Recapitulando, o consumidor ao escolher e comprar uma marca está também comunicando valores, estilos de vida, enfim compondo sua própria personalidade para se relacionar com os diversos grupos sociais com os quais ele interage. A escolha por determinada marca sofre a influência das características da mercadoria e do discurso da empresa e de suas campanhas publicitárias, ou seja, todo o conjunto que forma a identidade da marca. Terá mais sucesso a marca que conseguir colocar a essência de sua identidade de forma mais valorizada possível na mente do público receptor, este por sua vez terá uma imagem positiva sobre a marca desejando seus produtos.

Posicionar uma marca é o processo pelo qual se procura transmitir a essência da identidade da marca para a mente do público receptor. Primeiramente por meio de um enunciado dentro do briefing para a agência de propaganda, em segundo verificando se mensagem criada está de acordo com o enunciado e finalmente monitorando a recepção.

Para definir a essência da identidade da marca que deverá compor o enunciado do posicionamento e orientar toda a estratégia do sistema de comunicação será proposta uma metodologia que leva em consideração as possibilidades da marca de representar personalidades críveis, coesas e coerentes com a mercadoria, a empresa e o contexto cultural, político e econômico.

Essa essência será chamada de conceito fundamental, este nascerá de um jogo semântico entre funcionalidades e significados emocionais e percorrerá um caminho de geração de significação terminando no enunciado do posicionamento, o produto final deste processo.

Seguindo a semiótica greimasiana, o caminho de geração de significação caminha do abstrato, estrutura fundamental, para o concreto, o signo, o enunciado. A formação do posicionamento da marca também parte de algo abstrato, o seu conceito fundamental, e sobe para o nível narrativo, onde os valores entram em cena, até formar o discurso concreto representado pelo enunciado que declara o que a marca é, para quem ela serve e por que ela deve ser comprada. 
Voltando à essência da identidade da marca, é importante situá-la no contexto do mercado de marca. "A identidade de marca é o resultado deste complexo jogo de interações e de transformações, não somente aquilo que o produto libera para o público, nem o que o público recebe como mensagem... a identidade é a resultante da interação contínua e da troca incessante entre três sistemas: o contexto, recepção e a produção" (SEMPRINI, 1993: 73).

$\mathrm{Na}$ figura $X$ abaixo se tem um esquema dessas interações que resultam na identidade de marca e conseqüentemente no posicionamento. É importante ressaltar que estes três sistemas são dinâmicos, qualquer mudança em uma de suas variáveis listadas na figura, pode mudar as outras, ou seja, só se pode determinar a identidade de uma marca em um momento de sua história e em um determinado mercado.

Quadro X Identidade de marca

\begin{tabular}{|c|c|c|}
\hline & $\begin{array}{c}\text { Contexto } \\
\text { • Contexto social } \\
\text { • Contexto de mercado } \\
\text { • Legislação } \\
\text { • Concorrência } \\
\text { - Modificações vindas da } \\
\text { produção e recepção }\end{array}$ & \\
\hline $\begin{array}{l}\text { la produção } \\
\text { liscurso) } \\
\text { es da empresa } \\
\text { rto e longo prazo } \\
\text { cação } \\
\text { exto de mercado } \\
\text { xto sócio-cultural } \\
\text { ançamento } \\
\text { do público-alvo } \\
\text { do contexto sob a }\end{array}$ & $\underbrace{\begin{array}{c}\text { Identidade da } \\
\text { marca } \\
\text { (posicionamento) }\end{array}}$ & $\begin{array}{l}\text { Enciclopédia da recepção } \\
\text { - Atitudes e motivações } \\
\text { - Valores } \\
\text { - Sensibilidade sócio-cultural } \\
\text { - Prática de consumo } \\
\text { - Contextualização da identidade } \\
\text { da marca } \\
\text { - Interpretação da produção } \\
\text { - Percepção do contexto }\end{array}$ \\
\hline
\end{tabular}

\section{Enciclopédia da produção} (fabricação e discurso)

- Cultura e valores da empresa

- Objetivos - curto e longo prazo

- Mix de comunicação

- Visão do contexto de mercado

- Visão do contexto sócio-cultural

- Estratégia de lançamento

- Entendimento do público-alvo

- Entendimento do contexto sob a visão do público.
Enciclopédia da recepção

- Valores

- Sensibilidade sócio-cultura

- Prática de consumo

- Contextualização da identidade da marca

- Interpretação da produção

- Percepção do contexto

Fonte: SEMPRINI, 1993: 74 
Para interagir com esse três sistemas o conceito fundamental do posicionamento deve ser gerado levando em consideração o ethos de cada um dos sistemas, ou seja, ele deve apresentar-se afinado com a conjuntura ideológica, assumir um estereótipo estimulante para uma incorporação não somente da recepção, mas também da produção, pois fica muito mais convincente vender aquilo que se acredita. Além disso, deve-se considerar também a mitologia da mercadoria, aquilo que ela representa como objeto simbólico independente da marca.

Para atender essas demanda na geração da identidade da marca e suas interações com o mercado que é proposto a semiótica greimasiana e o seu caminho de geração de significação conforme Quadro XI a seguir. 
Quadro XI Estruturas para geração do posicionamento da marca

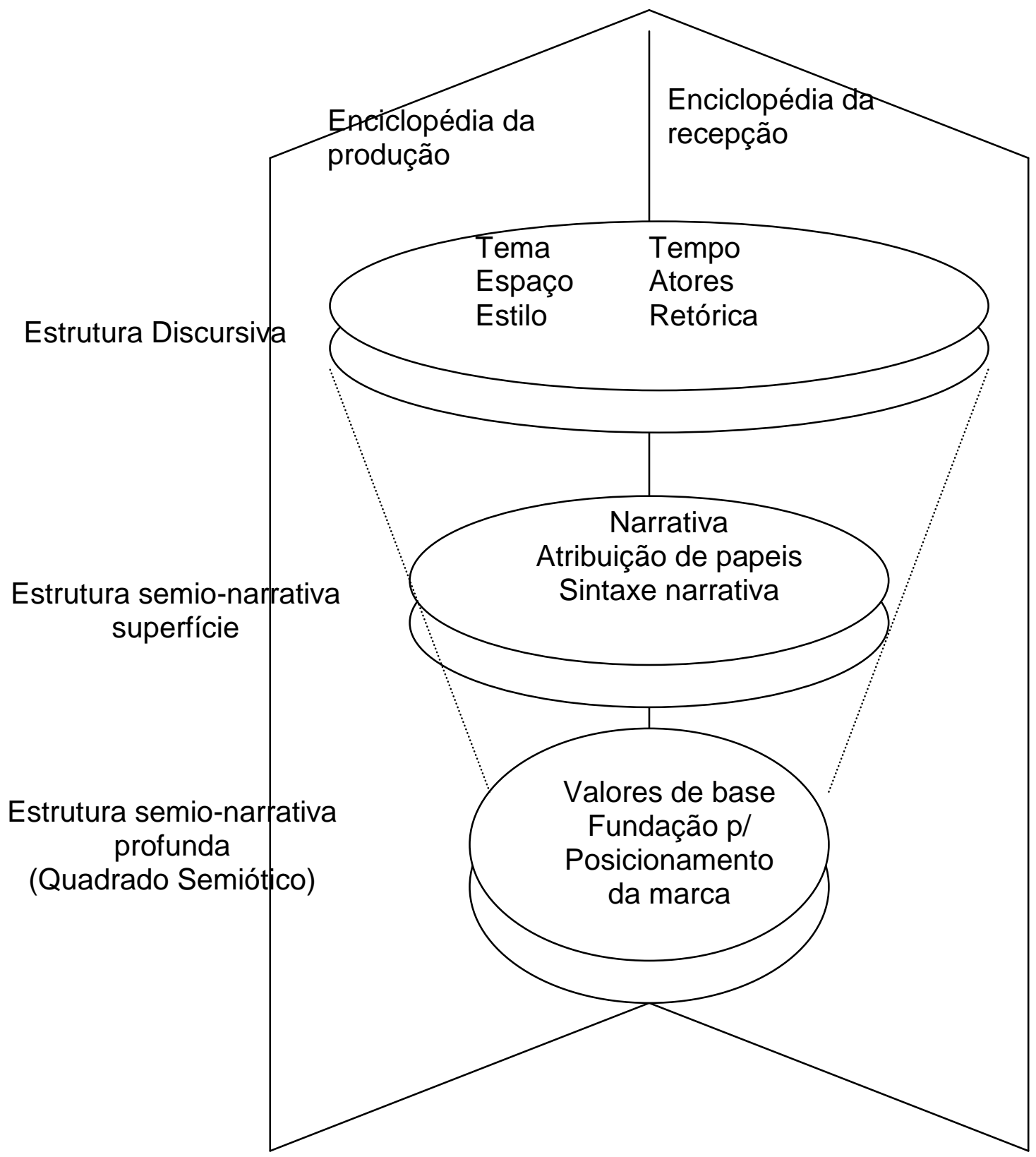

Fonte: SEMPRINI, 1993: 94 
O processo de elaboração do enunciado do posicionamento tem início na seleção do conceito fundamental, a essência da marca, que será colocada na base da estrutura de geração de significação. Para está escolha será utilizado o quadrado semiótico greimasiano adaptado por Floch para estudar a valorização do consumo. (FLOCH, 1993)

A oposição entre a valorização de uso, ou funcional, e a valorização de base, ou emocional, é o ponto de partida para a o caminho de geração da significação do posicionamento. Colocando-as num eixo semântico, tem-se a base para a construção do quadrado semiótico.

Floch trabalhou com esse quadrado estudando especificamente um automóvel. Partindo do eixo semântico e opondo as valorizações prática e de base, ou seja, os valores de uso (dirigibilidade, conforto, segurança) e os valores de base (a própria identidade do proprietário, status, virilidade, beleza, entre outros), o quadrado foi montado identificando quatro tipos de valorização: a prática, a utópica, a crítica e a lúdica (FLOCH, 1993: 147).

A valorização prática corresponde aos valores de uso, utilitários, funcionais, concebidos como contrários aos valores simbólicos, de base.

A valorização utópica corresponde aos valores existenciais, simbólicos, contrários aos valores de uso.

A valorização lúdica corresponde à negação dos valores utilitários ou funcionais, o lúdico e o prático são contraditórios entre si. Os valores lúdicos são o luxo, o refinado, uma pequena loucura.

A valorização crítica corresponde à negação dos valores utópicos, existenciais, o crítico e o utópico são contraditórios entre si. Exemplo de valores críticos: a qualidade e o preço. 
Quadro VIII - Valorizações no quadrado semiótico

\section{Prática Utópica}

$\begin{array}{ll}\text { Valores utilitários } & \text { Valores existenciais } \\ \text { (Valores de uso) } & \text { (Valores de base) }\end{array}$

Dirigibilidade

Conforto

Vida

Confiança

Custo/

benefício

Preço

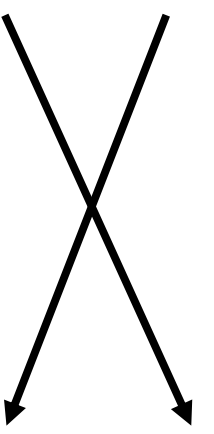

Identidade

Aventura

Gratuidade

Refinamento

Valores não

existenciais

Valores não

utilitários

Crítica

Lúdica

Fonte: FLOCH 1993: 148 


\section{Análise da concorrência}

Partindo do quadrado semiótico acima, Semprini construiu o seu "Mapa Semiótico“ dos valores do consumo, entendendo que os valores crítico e lúdico são qualificação dos valores primários, o prático e o utópico. Assim teremos de um lado, o crítico e o lúdico pertinente ao prático e do outro o crítico e o prático pertinente ao utópico, formando uma cruz.

\section{Mapa I}

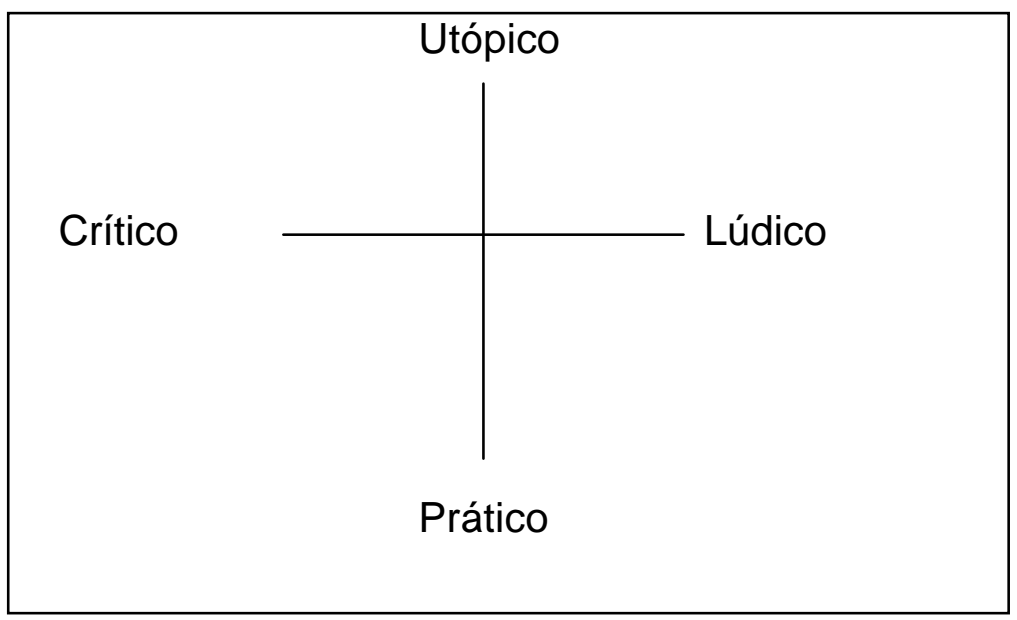

Fonte: SEMPRINI, 1993: 122

Esta ferramenta, proposta por Semprini, permite analisar a essência da identidade da marca em relação à concorrência, avaliando os pontos de paridade e de diferenciação. Cabe aqui ressaltar que está avaliação é uma fotografia de um determinado momento da marca no mercado. Ela não leva em consideração a dinâmica de valores da sociedade contemporânea de consumo. Esse assunto será tratado mais a frente. 


\section{Estrutura do mapa semiótico}

Para se por em prática o mapa semiótico de Semprini, será necessário entender cada um de seus quadrantes, a sua estrutura geográfica. Partindo do eixo vertical ou do horizontal é possível dividir o mapa em duas partes: Norte - Sul e Leste - Oeste. Este exercício é útil para se ter uma consciência da localização dos valores no mapa, e também para estudar as sobreposições lógicas, ou seja, no eixo vertical temos uma parte leste, dominada pelos valores lúdicos e uma parte oeste, dominada pelos valores críticos. Neste sistema de representação o crítico e o lúdico transformam-se em grandezas contínuas, compondo, com variações de nuanças de significado, toda uma metade do mapa.

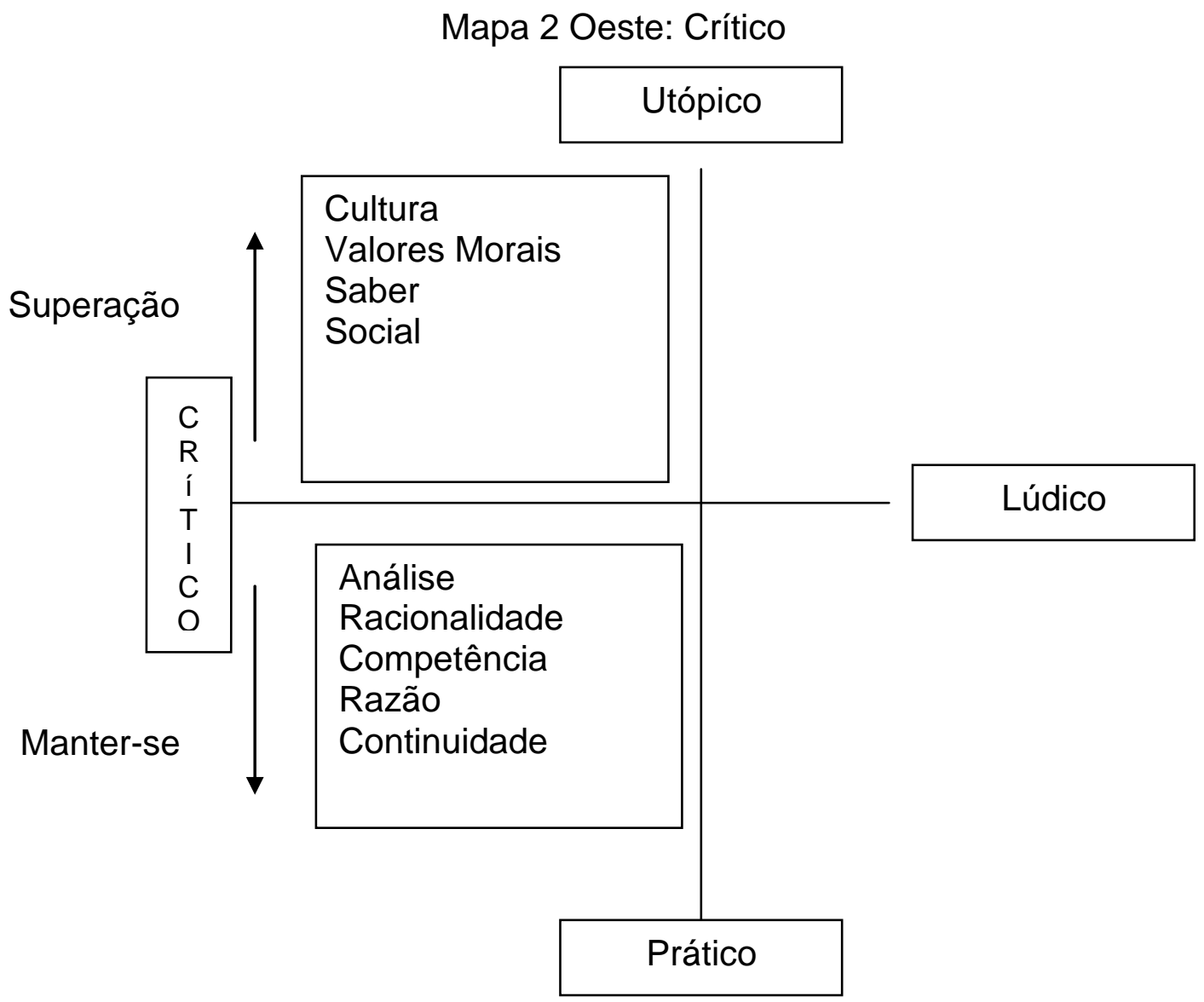

Fonte: SEMPRINI, 1993: 31 
Mapa 3 Leste: Lúdico

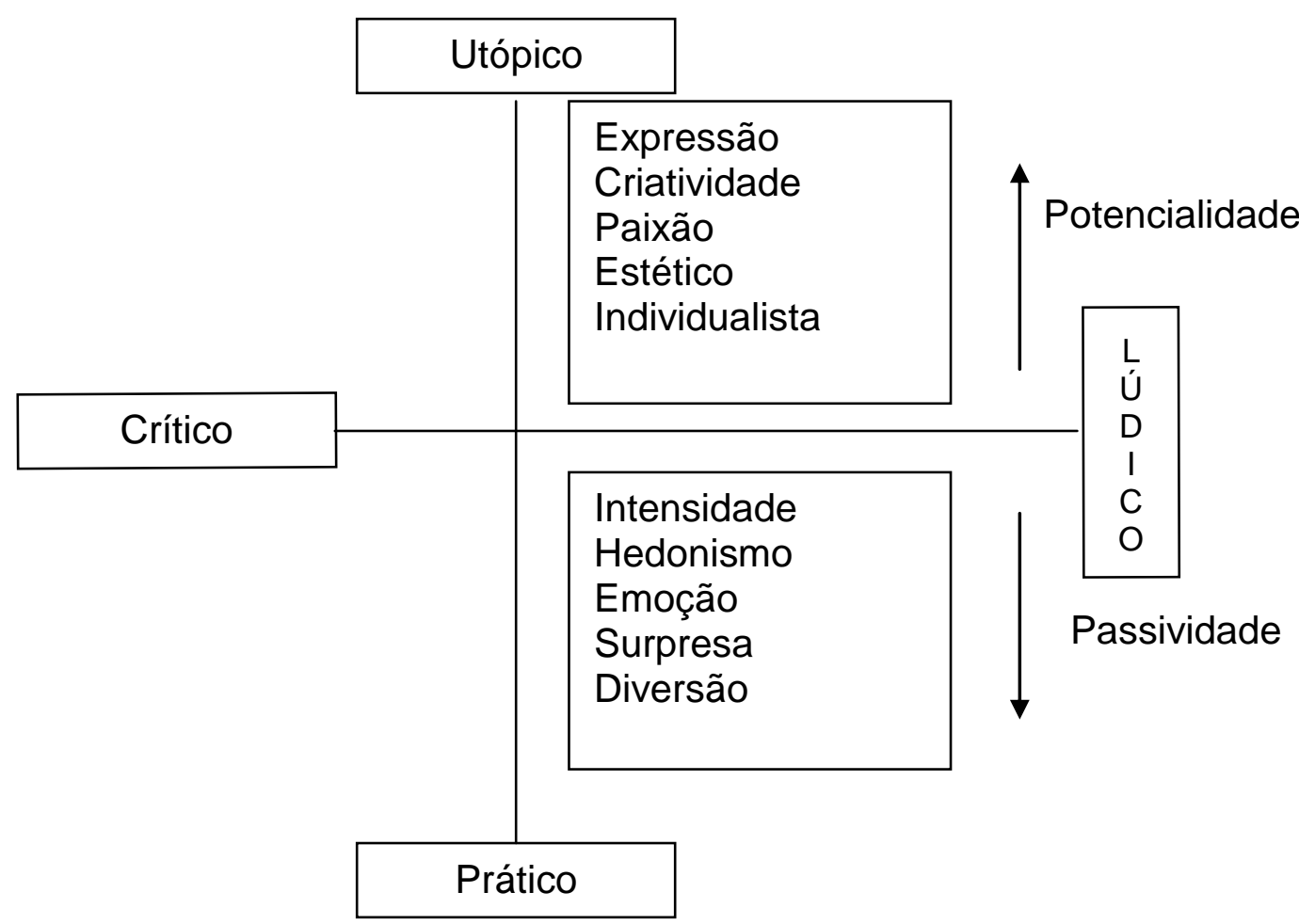

Fonte: SEMPRINI, 1993: 31

Do pólo norte utópico ao pólo sul prático temos duas escalas de valores, uma do lado oeste (mapa 2 crítico), outra do lado leste (mapa 3 lúdico) que vão mudando de intensidade, na razão em que se aproximam ou se distanciam destes pólos. Assim temos os quadrantes: Noroeste, com um caráter mais de superação cultural, moral e social; o Sudoeste com caráter mais reacionário, analítico, causal e de continuidade; Nordeste, com um caráter criativo, expressivo, apaixonado, individualista e por último o quadrante Sudeste com caráter Intenso, emocional, hedonista, divertido e propriamente lúdico. 
O mesmo raciocínio segue para definição dos quadrantes partindo da base norte e sul, mapas 4 e 5 abaixo:

Mapa 4 Norte : Utópico

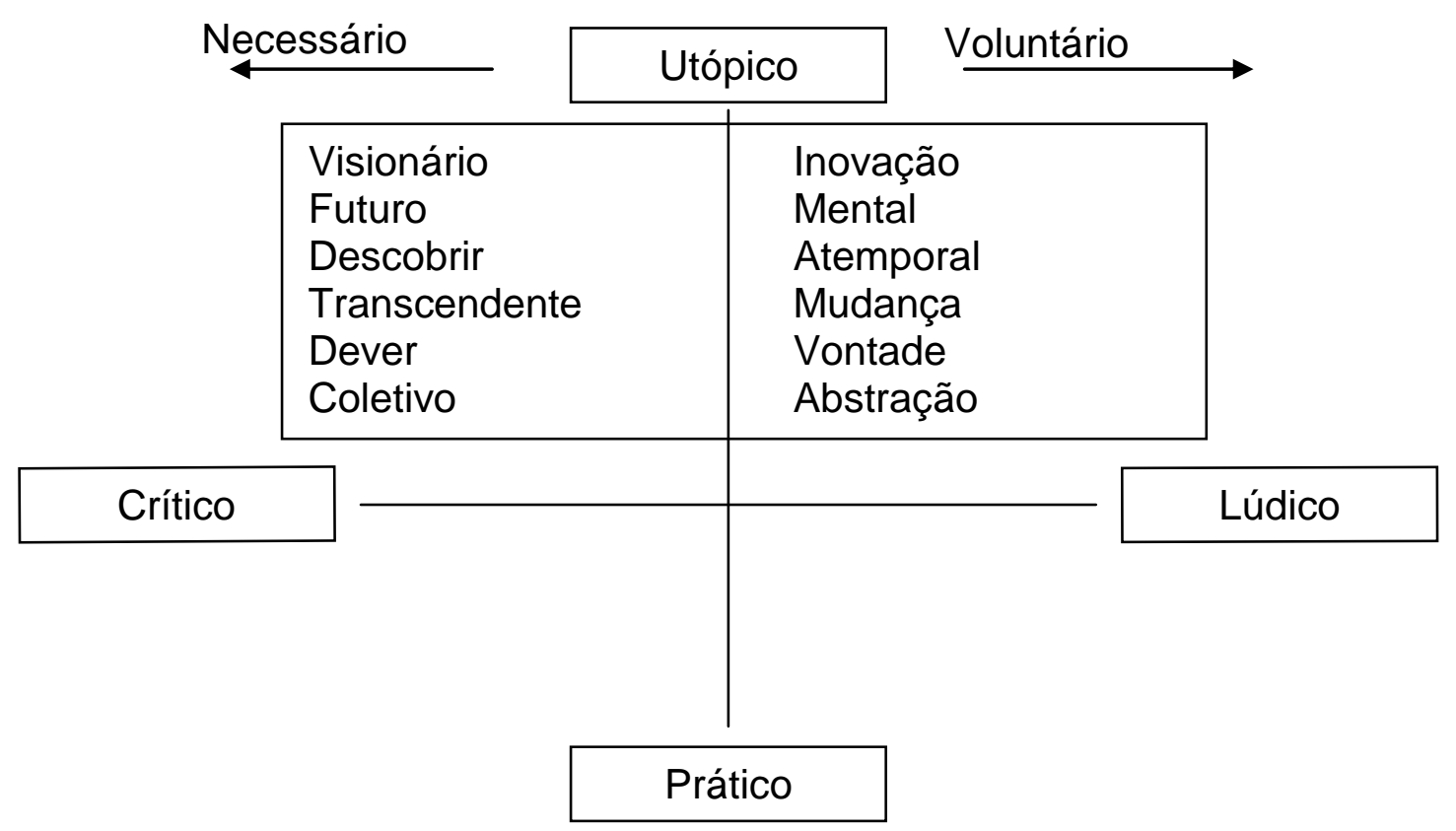

Fonte: SEMPRINI 1993: 135

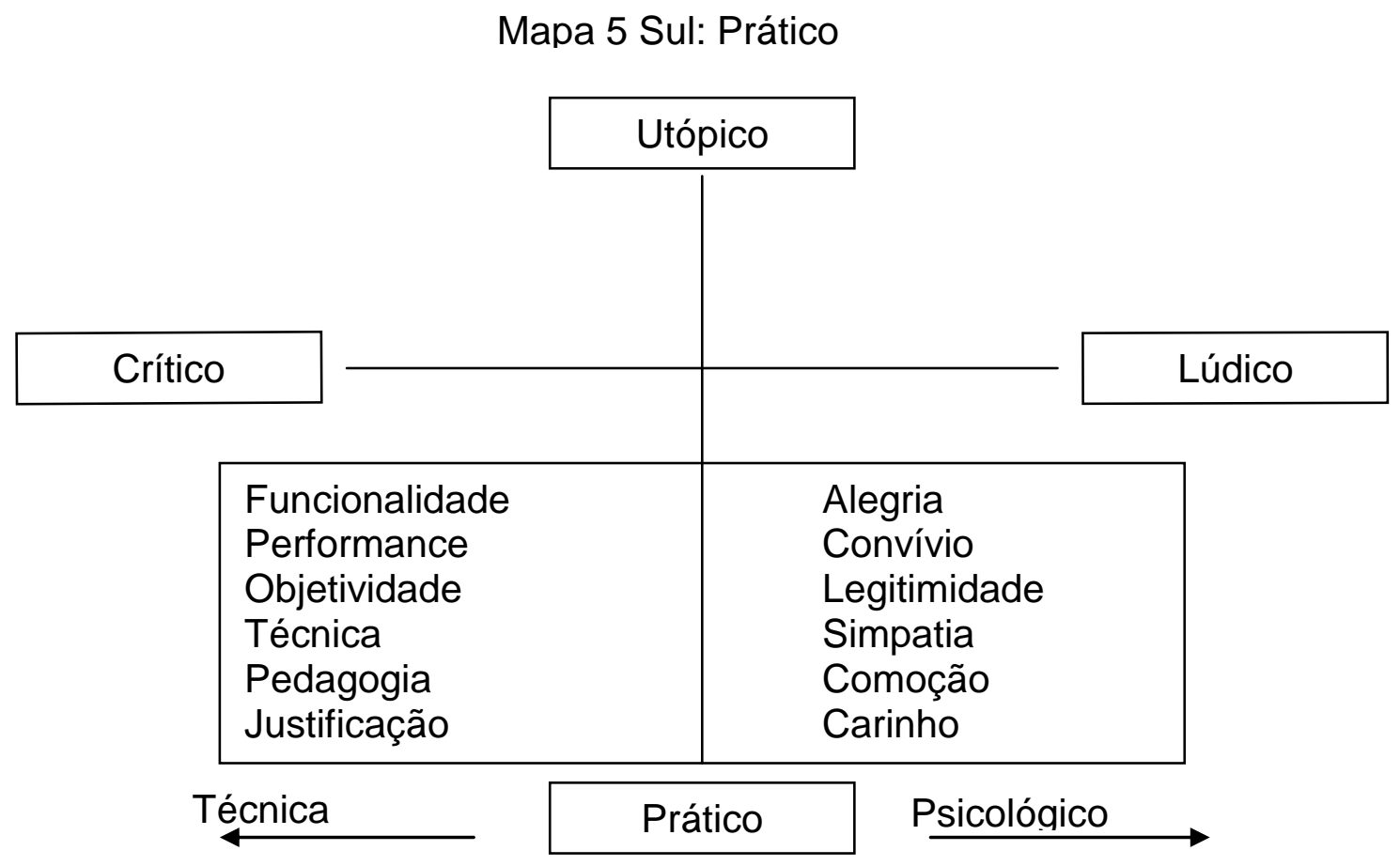

Fonte: SEMPRINI, 1993: 137 
O Resultado final é a composição de quatro definitivos quadrantes, que chamaremos de: Missão, entre crítico e utópico; Projeto, entre utópico e lúdico; Euforia, entre lúdico e prático e por último o quadrante chamado Informação, entre o prático e o crítico, todos representados nos mapas 6, 7,8 e 9 .

Mapa 6 Quadrante da Missão

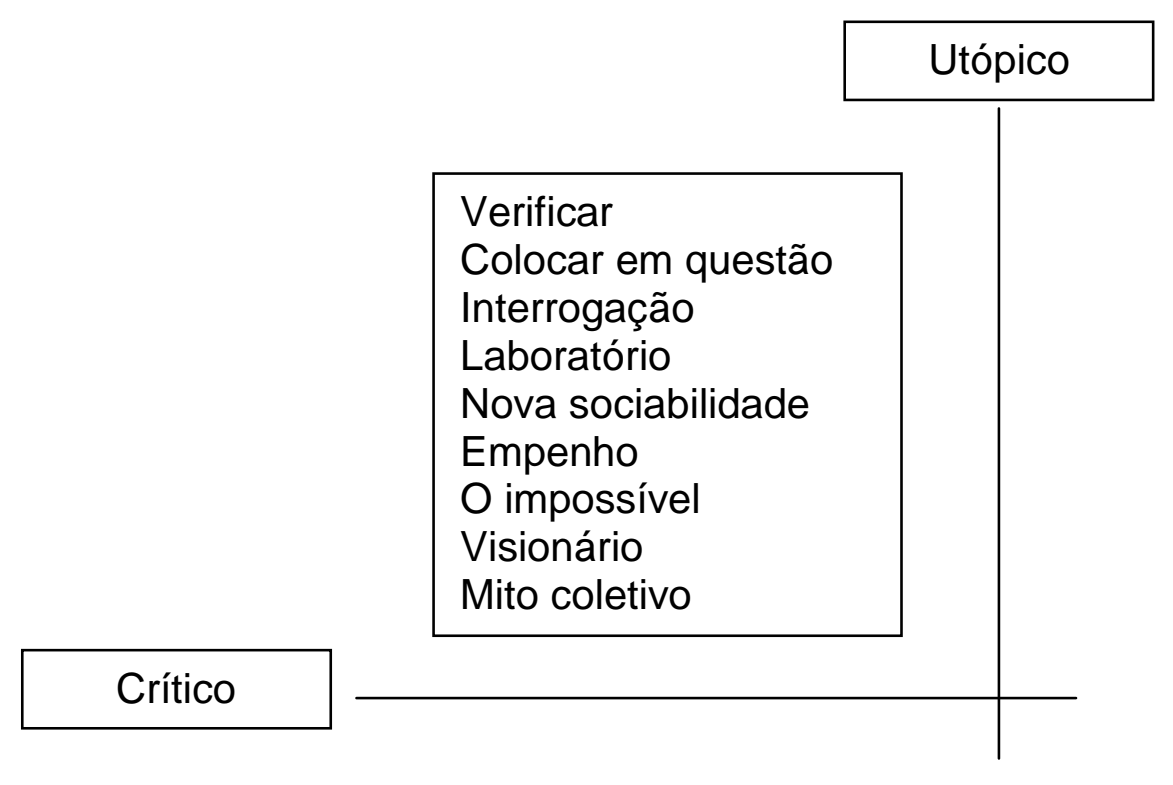

Fonte: SEMPRINI, 1993:141

Mapa 7 Quadrante do Projeto

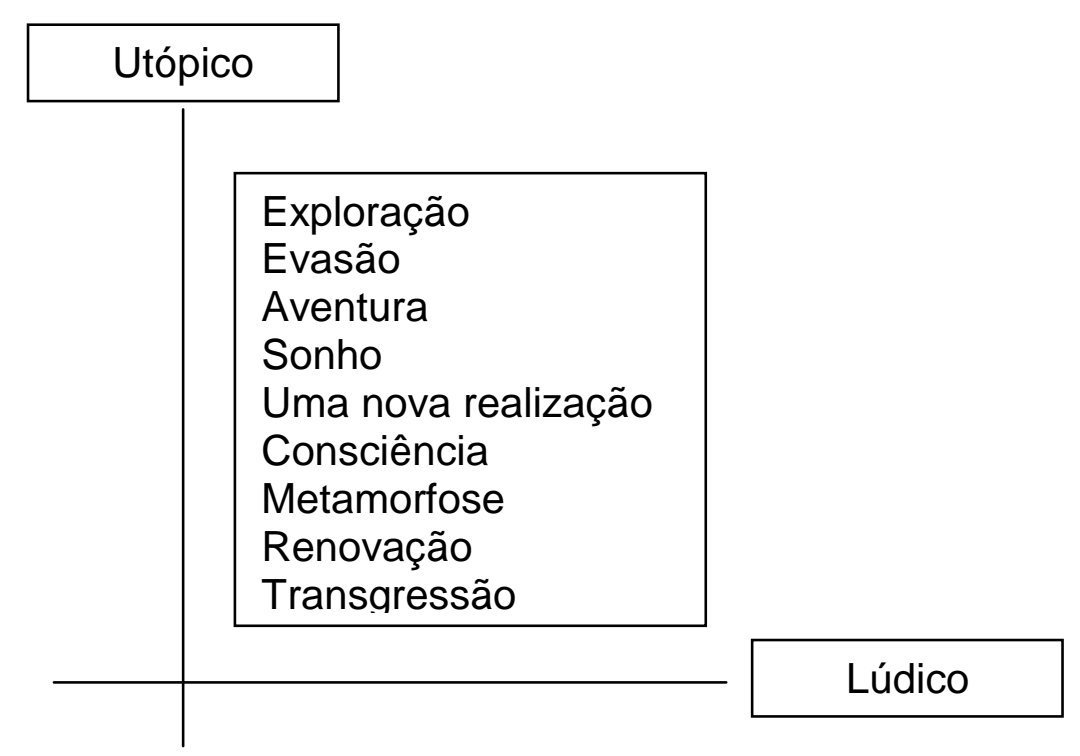

Fonte: SEMPRINI, 1993:143 
Mapa 8 Quadrante da Euforia

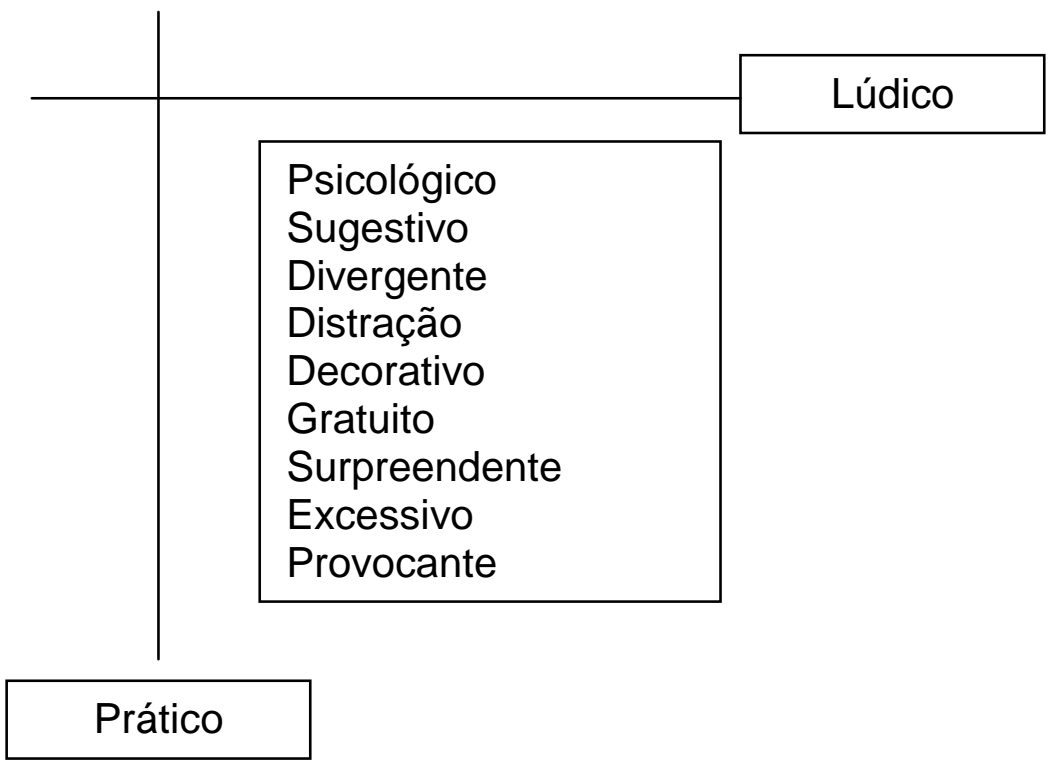

Fonte: SEMPRINI, 1993:145

Mapa 9 Quadrante da Informação

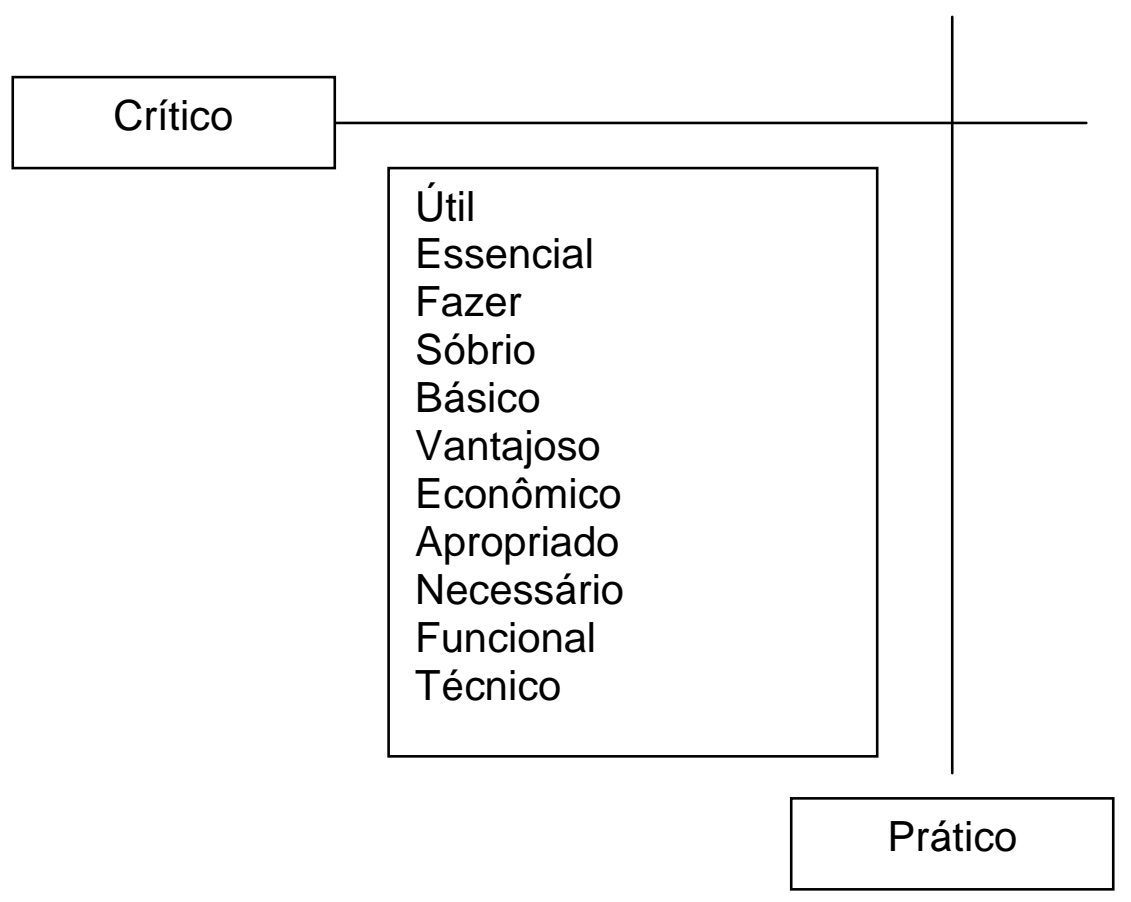

Fonte: SEMPRINI, 1993:148 
Os quadrantes; missão, projeto, euforia e informação; de Semprini permitem localizar onde se enquadra a marca analisada, bem como suas concorrentes, comparando-as em termos das paridades e diferenças.

O próximo passo é entender como o discurso evolui nas variáveis do enunciado como tempo, espaço, atores, relações e paixões. Para cada uma dessas variáveis será apresentado um mapa semiótico que serve como guia para não sair dos corredores isotópicos, ou seja, para dar coesão e coerência para ao discurso sem sair do conceito fundamental determinado em um ou mais dos quadrantes já vistos acima.

Mapa 10 O discurso da marca: Tempo

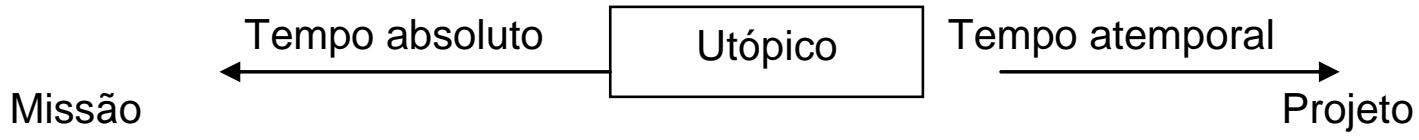

\begin{tabular}{|c|c|c|c|}
\hline $\begin{array}{l}\text { Tempo } \\
\text { paradoxal }\end{array}$ & $\begin{array}{l}\text { Tempo projetivo } \\
\text { Tempo paradoxal } \\
\text { Tempo arquétipo } \\
\text { Estória } \\
\text { Tempo cíclico } \\
\text { “De volta pro futuro }\end{array}$ & $\begin{array}{l}\text { Tempo relativo } \\
\text { Tempo mítico } \\
\text { Tempo abstrato } \\
\text { Tempo condensado } \\
\text { Efêmero } \\
\text { Tempo acelerado }\end{array}$ & $\begin{array}{l}\text { Tempo do } \\
\text { mito }\end{array}$ \\
\hline \multicolumn{4}{|c|}{ Crítico } \\
\hline \multirow[t]{2}{*}{$\begin{array}{l}\text { Tempo } \\
\text { mensurável }\end{array}$} & $\begin{array}{l}\text { Tempo ritualizado } \\
\text { Tempo cronológico } \\
\text { Tempo segmentado } \\
\text { A data } \\
\text { A duração } \\
\text { Tempo técnico } \\
\text { Tempo biológico }\end{array}$ & $\begin{array}{l}\text { Instante precioso } \\
\text { Tempo pessoal } \\
\text { Tempo Intenso } \\
\text { Passado como } \\
\text { emoção } \\
\text { Tempo psicológico }\end{array}$ & \multirow[t]{2}{*}{$\begin{array}{l}\text { Tempo da } \\
\text { consciência }\end{array}$} \\
\hline & & Inst & \\
\hline
\end{tabular}

Informação

Euforia

Fonte: SEMPRINI, 1993:154 
Mapa 11 O discurso da marca: Os espaços

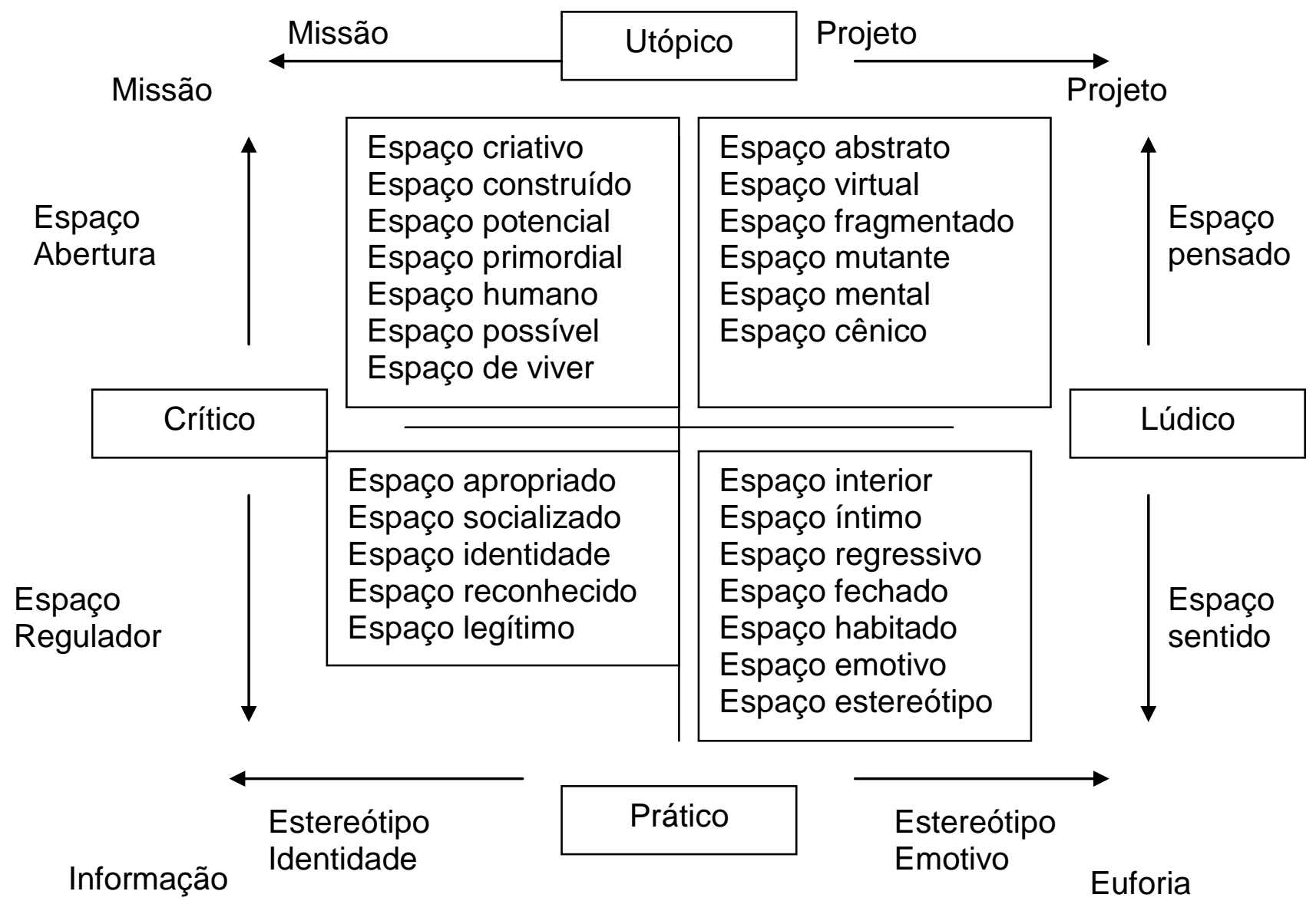

Fonte: SEMPRINI, 1993:157 
Mapa 12 O discurso da marca: Os atores

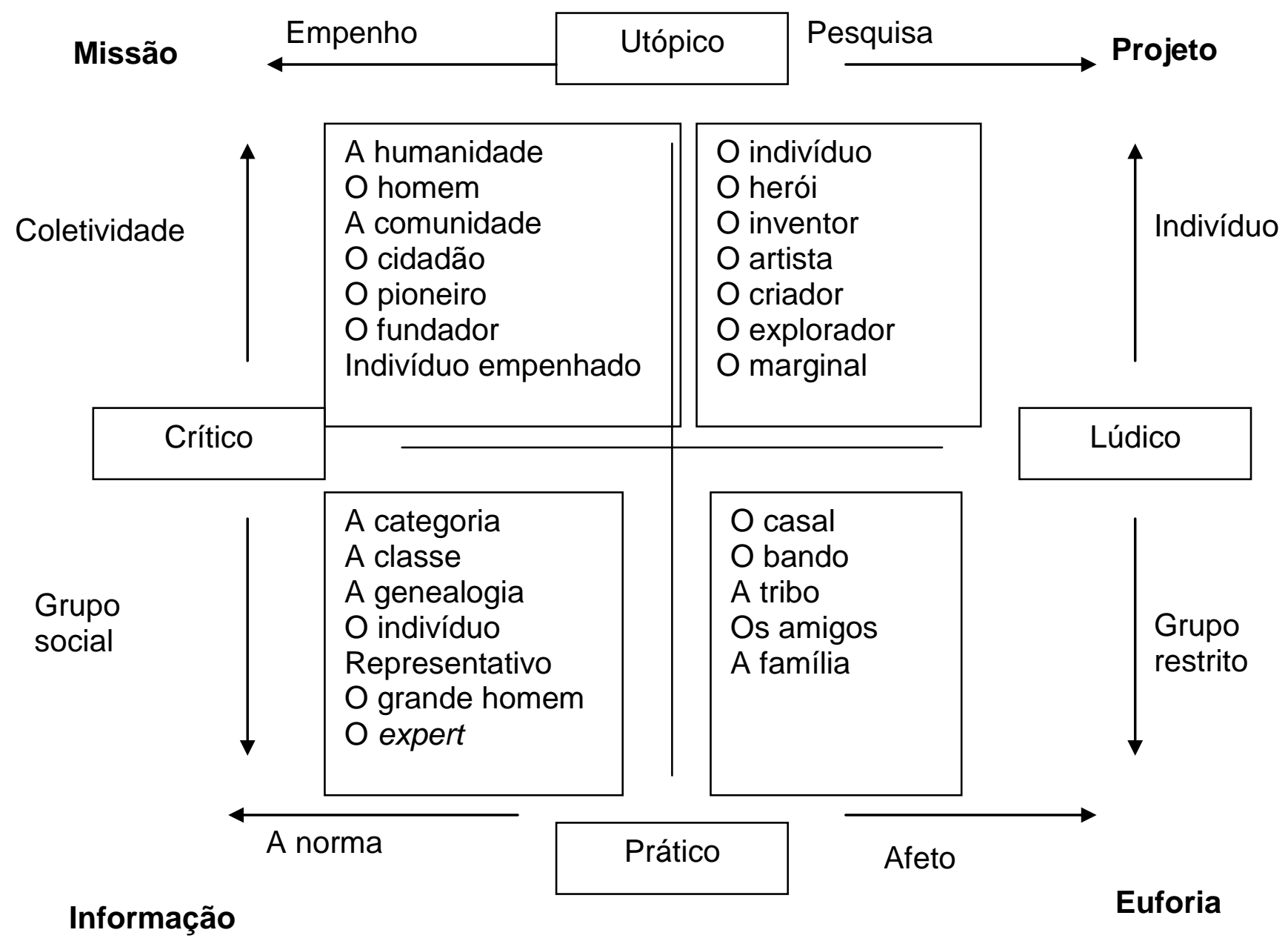

Fonte: SEMPRINI, 1993:160 
Mapa 13 O discurso da marca: As relações

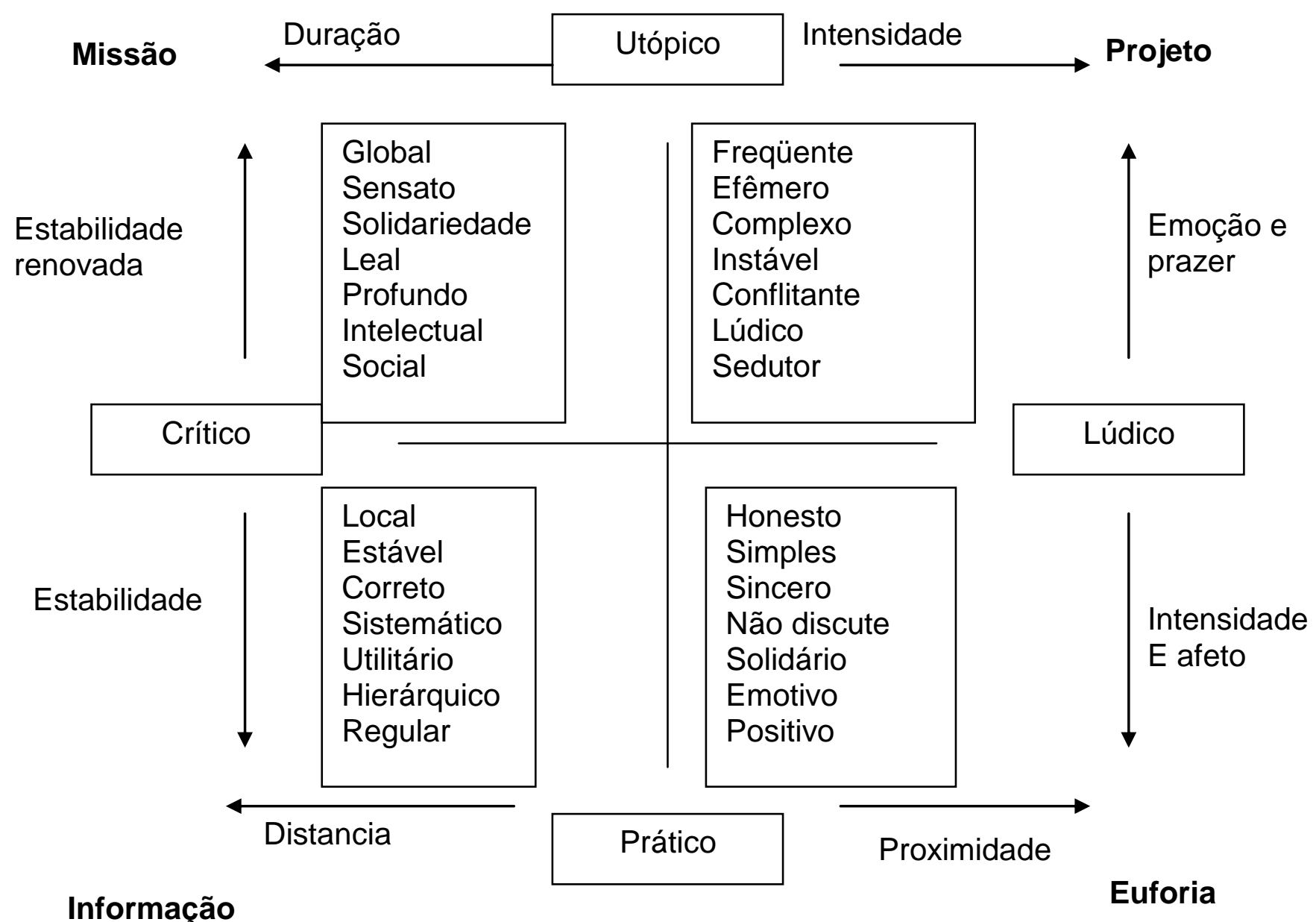

Fonte: SEMPRINI, 1993:163 
Mapa 14 O discurso da marca: As paixões

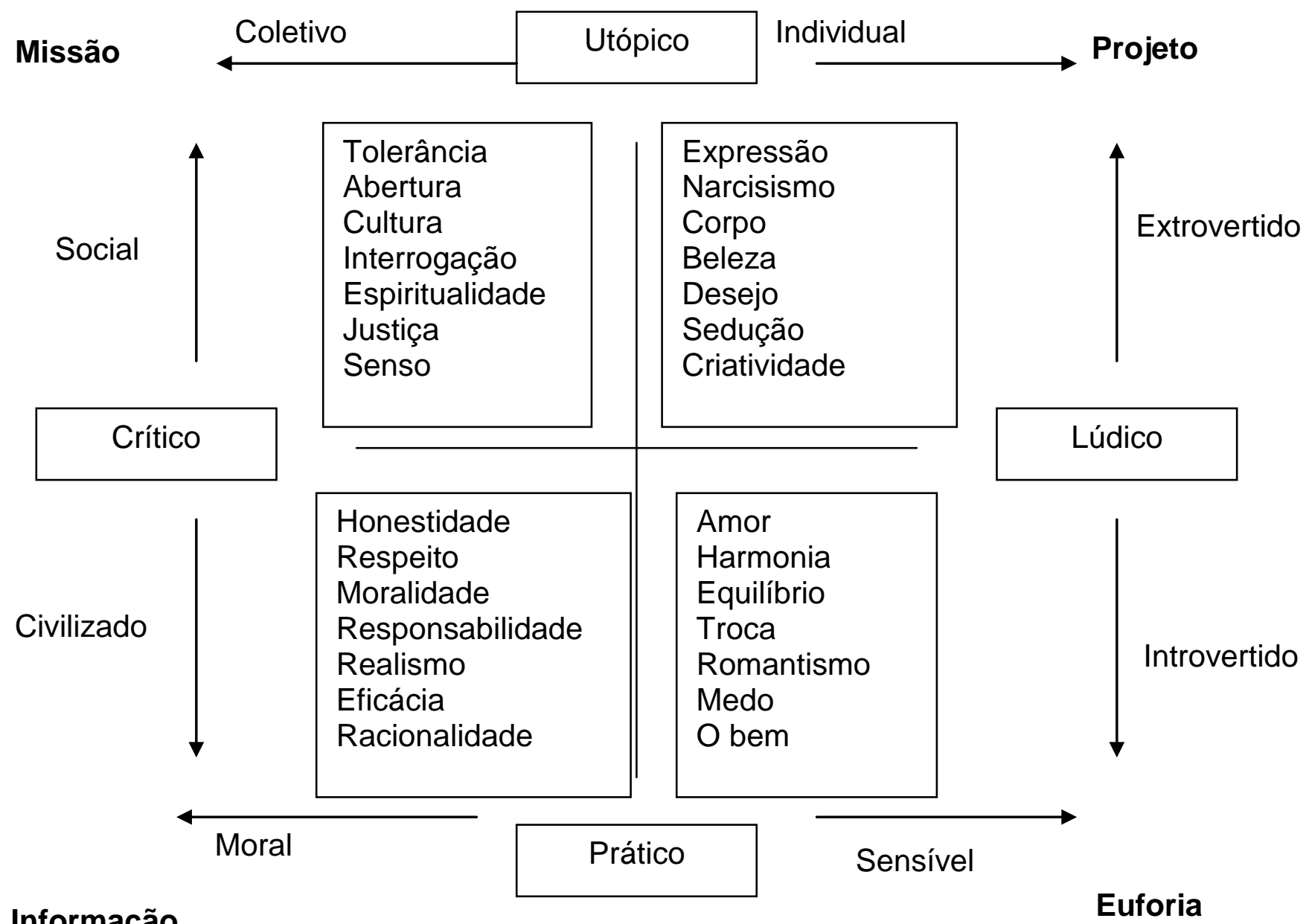

Fonte: SEMPRINI, 1993:167 
Abaixo exemplos de posições do discurso de algumas marcas nos quadrantes de Semprini

Mapa 15 O discurso da marca: Um exemplo

\section{Missão}

Utópico

Philip Morris

Benettton

Renault Clio

Adidas

Gatorade

Crítico

Philips

Total

Tropicana

\section{Informação}

\section{Prático}

Danone

Gillette
Sony

Coca diet

Swatch

\section{Projeto}

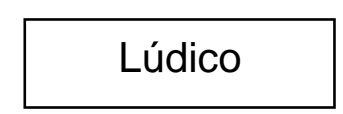

\section{Euforia}

Fonte: SEMPRINI, 1993:171

As marcas missionárias: Benetton etc. querem se superar propondo uma nova visão da sociedade, sugerindo novas fórmulas para novos problemas sociais. São marcas que questionam os velhos paradigmas. As marcas projeto também procuram a superação, porem não se preocupam com o aspecto social; elas se concentram mais no indivíduo. As marcas euforia propõem como valores fundadores as relações, a troca de afetividade e de sentimento. Por fim, as marcas informação são exclusivamente racionais e utilitárias. (SEMPRINI, 1993: 170) 


\subsubsection{Procedimento para o enunciado do posicionamento}

Após a análise, tendo como base o mapa semiótico de Semprini, de como a concorrência está posicionada e os pontos de paridade e diferenciação em relação à marca, o próximo passo é construir o enunciado do posicionamento. Para tanto a proposta de um posicionamento semiótico é constituída de duas partes. A primeira é relativa à síntese da essência da identidade da marca, ou seja, a identificação do conceito fundamental. A segunda e a construção do enunciado seguindo a metodologia greimasiana do caminho de geração de significação.

Identificação do conceito fundamental.

A análise da concorrência vai determinar "os espaços" dentro do mapa semiótico possíveis de serem ocupados pela marca, bem como uma gama de possibilidades de conceitos que poderão ser adotados. A escolha do conceito que representará a essência da marca deve ser feita considerando a pertinência e a credibilidade em relação aos três sistemas nos quais uma marca orbita: o sistema da produção (de mercadoria e do discurso), o contexto e o sistema da recepção.

1. Levantamento das informações da enciclopédia da produção

1.1 História, cultura e valor da empresa.

1.2 Objetivos estratégicos e de marketing.

1.3 Conjunto da identidade da marca (Nome da mercadoria, logotipo, design, embalagem, local de comercialização etc.).

1.4 Qualidades da mercadoria.

1.5 Análise do estoque perceptual da empresa.

1.6 Análise do estoque perceptual da mercadoria.

1.7 Análise do atual posicionamento da marca (se for o caso de uma marca já estabelecida no mercado)

2. Levantamento das informações da enciclopédia da recepção. 
2.1 Hábitos e motivações.

2.2 Valores.

2.3 Sensibilidade sócio-cultural.

2.4 Hábitos de consumo.

3. Levantamento das informações do contexto

3.1 Social, cultural, político e econômico.

3.2 Mercado.

3.3 Legislação.

3.4 Concorrência.

Quadro XII - Conceito fundamental

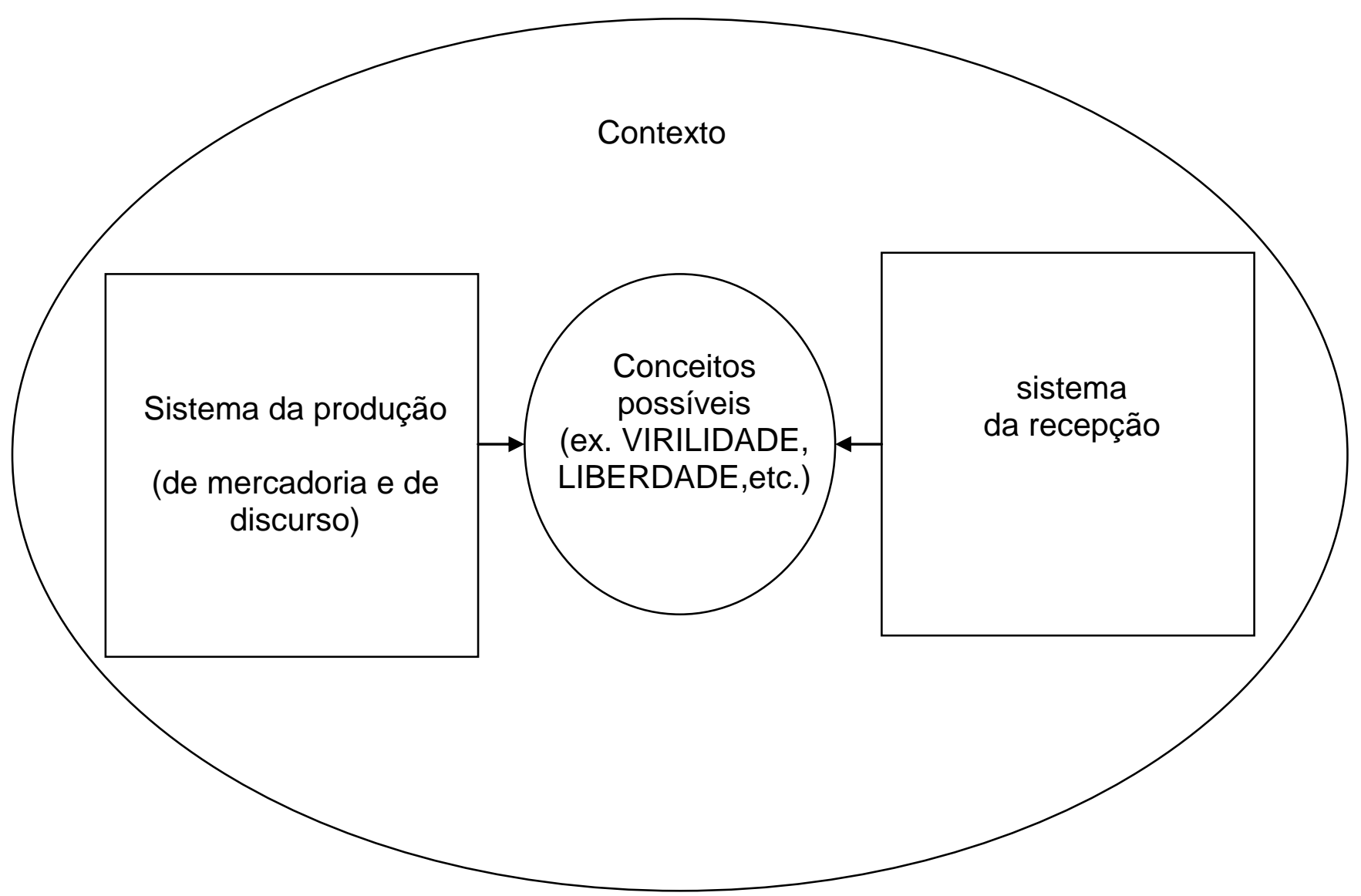

Construir o posicionamento como um enunciado, partindo do nível profundo e subindo pelas estruturas narrativas e discursivas até a manifestação do signo, é seguir o caminho de geração da significação proposto por Greimas assegurando que a essência da identidade da marca será declarada de forma completa e crível, se 
constituindo assim em um briefing inspirador para a agência de propaganda elaborar a campanha e a promessa em forma de slogan. Enunciar a identidade da marca é a matéria prima de toda a comunicação publicitária. "Assim como todo produto implica uma produção, todo enunciado implica uma enunciação" (Floch, 1993: 141).

Nas estruturas narrativas o sujeito vai encontrar todo o estoque de valores possíveis e de programas de ação necessários para ele "contar sua história". Nas estruturas discursivas se faz a seleção e a disposição no tempo e no espaço dessas virtualidades, realizando-as por meio dos papéis conferidos aos personagens para entrada em cena.

Vale lembrar que, dentro do caminho de geração de significação, a estrutura narrativa é dividida em dois níveis: no mais profundo está o quadrado semiótico, onde se definirão as posições por suas relações de contrariedade, contradição e de complementaridade; no mais superficial, as posições se convertem em valores. $\mathrm{Na}$ estrutura discursiva também há uma divisão entre o componente sintático, lógica dos acontecimentos, e o semântico, lógica da relação entre as posições e os valores.

\section{Estrutura semio-narrativa profunda.}

Selecionar os conceitos possíveis e escolher o mais apropriado faz parte do componente semântico da estrutura semio-narrativa profunda. (ver quadro II) No lado sintático serão constituídos os actantes básicos. A partir disso se inicia a marcha do herói para encontrar o discurso do posicionamento.

4.1 Quadro da dialética entre produção e recepção.

4.2 Quadrado semiótico e Mapa semiótico.

4.3 Definição dos actantes.

Graças ao trabalho desenvolvido por Propp foi possível distinguir entre um actante e um ator. O actante é definido pela função na narrativa e por sua relação com os outros actantes, sem a interferência da noção de tempo e espaço, sendo que no discurso essa função pode ser assumida por vários atores.

5. Estrutura semio-narrativa de superfície. 


\subsection{Sintaxe narrativa}

\subsection{Semântica narrativa}

A sintaxe narrativa estabelece duas relações fundamentais entre actantes. A primeira é os sujeitos / objeto. Esta é uma relação de busca, de intenção; cria a tensão necessária para iniciar um relato. A segunda, a relação entre destinador / destinatário, é uma relação de comunicação de um objeto. Existem outras relações que podem fazer parte da narrativa, a mais interessante para esse estudo é a oponente / ajudante; cujo mecanismo pode definir o sucesso ou o fracasso do sujeito em sua busca pelo objeto desejado.

Esse relato nada mais é que uma circulação de objeto entre sujeitos, que adquirem um estado disjunto ou conjunto com o objeto, formando então duas categorias fundamentais: conjunção de disjunção e sujeito de estado (disjunto ou conjunto) vs. sujeito de fazer (sujeito que realiza um passo de um estado a outro)

$\mathrm{O}$ esquema narrativo da quadro VI mostra as provas pelas quais o sujeito herói deverá passar para ser consagrado, ou seja, as partes do processo narrativo para se obter o discurso do posicionamento na fase seguinte.

O próximo passo dentro da estrutura semio-narrativa de superfície será no lado semântico com a atualização dos valores selecionados na fase anterior para uma escolha paradigmática respeitando a isotopia da narrativa.

\section{Estrutura discursiva}

6.1 Sintaxe discursiva

\subsection{Semântica discursiva}

O esquema narrativo da fase anterior é assumido pelo sujeito da enunciação que o vai converter em discurso. No nível discursivo os actantes assumem um discurso localizado no tempo e no espaço, com uma tematização concatenada de forma homogênea nos corredores isotópicos.

"Enunciação é o ato de produção de discurso... é o eu aqui e agora" (FIORIN, 2001: 39) Aqui e agora implica nos três elementos de discursivização: a 
actorialização, a espacialização e na temporalização, ou seja, a constituição das pessoas no tempo e no espaço.

O sujeito produtor do discurso, o enunciador, se faz persuasivo, enquanto o enunciatário se faz interpretativo. Para o enunciador persuadir ele lança mão de um conjunto de elementos argumentativos. A sintaxe do discurso tem como objetivo levar o enunciatário a aceitar o que está sendo comunicado.

A sintaxe do discurso se faz nas projeções da enunciação no enunciado e nas relações entre enunciador e enunciatário. No primeiro se usam para constituir um discurso os dispositivos: actancial, espacial e temporal projetados pelo mecanismo de debreagem na forma enunciativa, primeira pessoa, e enunciva, terceira pessoa. A primeira pessoa dá um caráter mais subjetivo ao discurso, enquanto a terceira passa uma objetividade maior.

As relações entre o enunciador e o enunciatário se baseiam na premissa que a finalidade da comunicação não é informar, mas é persuadir o outro a aceitar o que está sendo comunicado, e para isso se vale de procedimentos argumentativos de ilustração e figuras de pensamento.

A ilustração ocorre quando no texto fala-se de um caso que valida uma afirmação geral para todos. Exemplo: "É possível chegar a pé em Curitiba, saindo de São Paulo. Um homem de trinta anos caminhou por dez dias, saindo de da capital paulista para chegar até a capital do Paraná"

As figuras de pensamento podem aparecer nas relações semânticas e na sintaxe discursiva, nesta última as mais comuns são: Ironia, lïtotes, preterição e reticências.

A semântica discursiva concretiza as mudanças de estado do nível narrativo através da tematização ou figurativização. A figurativização é a utilização de termos do mundo natural, concreto, proporciona um efeito de realidade. A tematização é o investimento semântico, de natureza conceitual que não remete ao mundo natural, usado para explicar a realidade.

Dentro das varias possibilidades de leitura de um texto é a reiteração a repetição de traços semânticos idênticos que garante a unidade de sentido de um discurso que guia o leitor no sentido correto. Esse plano de leitura se chama 
isotopia. Recursos mais comuns de retórica, como metáforas e metonímias são conectores de isotopia.

7. Plano de manifestação - Discurso do posicionamento

Por fim é possível elaborar um discurso de posicionamento para a mercadoria, acrescentando-o ao briefing para a agência de propaganda, contando uma história de uma mercadoria que busca uma identidade para ser amada e desejada, e que, por meio das estratégias e de um plano tático de marketing, pode potencializar as oportunidades e eliminar as ameaças, mostrando o valor que o publico quer ver e onde ele pode encontrá-la.

Finalizando, como exemplo de aplicação do posicionamento semiótico de marca, o anexo 1 mostra com detalhes essa metodologia. Na dissertação de mestrado deste pesquisador foi realizado o posicionamento da marca MercedesBenz Classe A, carro compacto lançado no Brasil em maio de 1999, cuja produção foi até 2004. Neste exemplo fica bem claro a utilização da ferramenta semiótica e sua pertinência como metodologia para o posicionamento de marca. 


\section{A CULTURA DE CONSUMO E O AUTOMÓVEL.}

Este capítulo tem como objetivo pontuar aspectos importantes relativos à cultura de consumo na sociedade contemporânea, que se relacionam diretamente com o consumo do automóvel, possibilitando analisar o mercado, o consumidor e a mercadoria em si sob uma ótica muito mais qualitativa que quantitativa.

Para tanto, foi elaborada uma pesquisa bibliográfica sobre as principais características da sociedade contemporânea e como ela se relaciona com o automóvel. Infelizmente muito pouco ou quase nada foi encontrado em relação à cultura do automóvel no Brasil.

Os dados e informações trazidos aqui são originados na experiência prática deste pesquisador e em algumas publicações acadêmicas realizadas no exterior.

Ao longo do capítulo, serão ressaltados alguns conceitos que serão conectados mais a frente para suportar a tese principal desta pesquisa. Estes conceitos são: a construção da identidade do indivíduo por meio do consumo de marcas e mercadorias, o ritmo vertiginoso de mudanças e reciclagens de conceitos na sociedade e a nova dinâmica de desejos relativa ao consumo de marcas e mercadorias. 


\subsection{Cultura de consumo na sociedade contemporânea}

Ao longo do processo evolutivo pelo qual passou, o ser humano deixou de se guiar pelos seus instintos e adotou padrões culturais para se relacionar com seu semelhante e com a natureza. Tais padrões incluem conhecimentos, crenças, arte, moral, leis, costumes ou qualquer outra capacidade ou hábito adquirido pelo homem como membro de uma sociedade. (Tylor, 1871, apud LARAIA, 2007) O ser humano vai assim se adaptando às circunstâncias do meio e acumulando esses conhecimentos como mecanismo de sobrevivência, conferindo uma dinâmica à cultura.

Após a Revolução Industrial, com o avanço tecnológico, principalmente dos meios de comunicação, incrementou-se o processo de homogeneização da cultura, no qual padrões de comportamento começaram a ser massificados. Neste contexto, com a proliferação de novas mercadorias industrializadas, o consumo passa a ser uma atividade de grande destaque na sociedade moderna.

Com as novas técnicas de produção seriada, as mercadorias, antes artesanais, passam a ter marca e um padrão de qualidade; além disso, novos objetos são inventados e fabricados, criando novas necessidades e novos hábitos. A publicidade comercial passa a atuar diretamente na sociedade, incentivando o consumo dessas mercadorias e formando assim uma cultura de consumo.

Segundo Mike Featherstone, a cultura de consumo tem três perspectivas fundamentais, resumidas abaixo: (FEATHERSTONE, 1995: 31)

A expansão da produção capitalista de mercadorias gerou cultura material e o prazer em consumir mercadorias, como expressão de uma liberdade individual.

A relação entre satisfação proporcionada pelos bens e seu acesso socialmente estruturado é um jogo de soma zero, no qual a satisfação e o status dependem da exibição para a sociedade. As pessoas usam as mercadorias para criar vínculos ou estabelecer distinções sociais.

O consumo traz prazeres emocionais, sonhos e desejos celebrados no imaginário cultural consumista e em locais específicos de consumo que produzem diversos tipos de excitação física e prazeres estéticos. 
Se se junta a isto o conceito de Baudrillard referente a mercadorias como signo, e o seu consumo como "uma atividade de manipulação sistemática de signos" (BAUDRILLARD, 2000: 206), tem-se como resultado um sistema de produção no qual a mercadoria-objeto e a mercadoria-discurso se integram com o público receptor (SEMPRINI, 1993: 490), para que este construa sua própria identidade com a liberdade de escolher o que consumir.

Assim, a identidade na cultura de consumo é comprada, extraindo-se significados subjetivos, sugeridos pelo sistema de discurso da mercadoria, dos significantes objetivos. Por sistema de discurso da mercadoria entende-se toda forma de comunicação, seja do produtor ou da sociedade, sobre a mercadoria e sua marca, mas, predominantemente, é o discurso publicitário quem mais provê à mercadoria os significados desejados pelo consumidor.

$\mathrm{Na}$ cultura de consumo, o forte apelo imagético proporcionado pela mídia na distribuição do discurso publicitário distancia o consumidor cada vez mais do objeto referente, o que possibilita um intercâmbio de significados e significantes Os signos sugeridos pela publicidade ficam assim independentes do objeto e disponíveis para associações à marca e à construção das identidades escolhidas pelo consumidor.

A mercadoria e sua marca funcionam então como mediadoras entre o sistema da produção e o indivíduo, o qual, por meio de suas escolhas na experiência de consumo, constrói a sua identidade conforme um determinado estilo de vida. Entende-se por estilo de vida uma "consciência estilizada de si", segundo Featherstone. Essas escolhas são vistas como indicadores da individualização, do gosto e senso de estilo do consumidor (FEATHERSTONE, 1995:119).

Até este ponto tem-se que o indivíduo consome uma mercadoria para, além de suprir suas necessidades práticas de sua vida, através das funcionalidades deste objeto, extrair significados que vão compor sua identidade, adotando um ou vários estilos de vida, satisfazendo, assim, desejos e necessidades emocionais para sua convivência em sociedade.

Importante destacar que na sociedade contemporânea o indivíduo que vai às compras vai em busca de algo mais além da necessidade de se destacar ou se inserir em classes sociais, como frisava Baudrillard, ao afirmar que as mercadorias eram consumidas pela sua capacidade de se diferenciar, de remeter o consumidor a 
uma posição, um status (BAUDRILLARD, 2000). Não restam dúvidas de que isto ocorre com freqüência, principalmente com indivíduos em ascensão dentro de seu grupo, mas o que se observa atualmente é que o consumo está também suprindo necessidades emocionais, corporais e estéticas. "O consumidor quer mercadorias para viver mais que para exibir" (LIPOVETSKY, 2007: 42), ele exercita sua criatividade e seu poder de compra para montar o seu próprio estilo, que incorpora uma multiplicidade de papéis provenientes dos discursos das mercadorias os quais, embora padronizados pela publicidade, são reinterpretados e re-configurados para expressar sua identidade, seus valores e seu projeto de vida.

Outro aspecto a ser destacado é o relativo à velocidade das mudanças na sociedade contemporânea e o valor da novidade. Na busca por uma diferenciação para atrair o consumidor às mercadorias, segue-se o sistema da moda, cuja lógica é uma constante necessidade de inovar. Aliando-se a isto o desenvolvimento tecnológico acelerado, reduzindo o ciclo de vida das mercadorias, tem-se como resultado um ritmo de mudança das coisas cada vez mais rápido.

Como exemplo disto pode-se citar o telefone celular. No início de sua comercialização no Brasil, na década de 1990, os modelos eram grandes, pesados e as baterias duravam em torno de 90 minutos. Hoje em dia, eles são pequenos, muito leves, suas baterias duram mais de um dia e eles não se limitam mais à função telefônica, disponibilizando para o usuário acesso à Internet, músicas, vídeos e câmera fotográfica.

$\mathrm{Na}$ corrida entre os fabricantes pelas vendas e domínio de mercado, uma novidade que diferencie a mercadoria faz com que esta fique por certo tempo à frente dos seus concorrentes. O discurso publicitário reveste esta nova funcionalidade com valores subjetivos e emoções a serem experimentadas. Isto vai durar até outro concorrente desenvolver um novo modelo, o que em geral é muito rápido.

Como resultado desta corrida, há uma sucessão de lançamentos, novidades e inovações, fazendo o consumidor valorizar o conceito do atual, do novo, do mais moderno. As mercadorias, bem como seus discursos, e portanto todo um sistema de significação, terá um ciclo de vida muito curto, não deixando tempo suficiente para sua solidificação, formando o que Bauman chama de "sociedade líquida - moderna" 
(BAUMAN, 2007: 7), que é aquela em que as condições mudam num tempo muito curto, impossibilitando a consolidação de hábitos e rotinas da forma de agir.

Sob tais condições, a suposta missão das mercadorias de satisfazerem os desejos de seus consumidores, como dito anteriormente, nunca se cumpre. $\mathrm{Na}$ cultura de consumo a insatisfação do desejo é fundamental para levar o consumidor a buscar sempre mais e cada vez mais rápido. "O caminho da loja à lata de lixo deve ser curto e a passagem, rápida" (BAUMAN, 2007: 108) Contudo, pode-se afirmar, com base em Bauman, que a cultura de consumo está para a incitação do desejo, e não para a sua satisfação, e com sua vertiginosa velocidade sua função é girar o "ciclo do desejo" (BAUMAN 2007: 121) o mais depressa possível.

Para continuar extraindo significados das mercadorias com a finalidade de construir sua identidade, o consumidor necessita estar sempre muito bem informado e aberto para possíveis reciclagens de conceitos e estilos. Isto faz supor que a identidade do consumidor é algo dinâmico e sujeito a reformulação constante.

Essa busca por informação, somada à publicidade ofertando satisfação de desejos, gera no consumidor uma enorme ansiedade, que o impulsiona a estar sempre buscando a felicidade em cada loja e se confrontando com uma nova informação, mais a incitação ao desejo, resultando numa interminável construção e reconstrução de seus estilos de vida.

A leitura de Bauman revela que o ritmo espantoso de mudança transformou a sociedade que ora vive uma "vida líquida". Tudo é fluido e transitório, emprego, empresas, parceiros, rede de amizades e até a auto-estima. A solução para não se liquefazer por completo seria se concentrar naquilo que se pode influenciar, ou seja, minimizar os riscos pessoais, cuidando da saúde, da forma física, da segurança domiciliar e veicular. (BAUMAN, 2007)

Além da integridade física, o indivíduo busca uma integridade mental. Longevidade sim, mas com lucidez. Há uma busca pela paz interior. O bem-estar é o novo objeto de desejo. Esta é a conclusão de uma detalhada pesquisa realizada por Melinda Davis, que aponta para uma nova dinâmica de motivação baseada numa nova forma de como a realidade se apresenta nos dias de hoje.

Devido a um desequilíbrio entre o nível da experiência e o nível do pensamento, no qual este último vem cada vez mais sobressaindo como resultado 
de uma grande exposição a uma realidade mediada por telas e imagens e um distanciamento da realidade exterior e sensível, o indivíduo hoje vive um mundo imagético. Neste, a realidade acontece na consciência do indivíduo, e por este motivo a saúde mental, a lucidez, passa a ser o bem maior e, conseqüentemente, o desejo fundamental passa a ser o bem-estar. (DAVIS, 2003)

Nessa mesma linha Gilles Lipovetsky define o consumidor atual como desajustado, instável e flexível, que, liberto das antigas culturas de classes, está à procura de experiências emocionais que Ihe propiciem maior bem-estar, qualidade de vida e saúde, conforto psíquico, harmonia interior e um desenvolvimento pessoal. (LIPOVETSKY, 2007)

Resumindo, o indivíduo, para se inserir na sociedade, necessita consumir significados, extraídos das mercadorias e suas marcas, que vão ajudá-lo a construir o seu próprio estilo, o seu eu, a sua identidade. Estes, como também as mercadorias e seus significados, encontram-se em constante mutação, o que o obriga a estar constantemente informado e consumindo.

Toda essa dinâmica que envolve informação, poder de compra e necessidade de suprir desejos, aliada a uma crescente exposição ao mundo imagético, está provocando uma necessidade de harmonia, paz interior, bem-estar e segurança física e emocional.

É nesse contexto que será abordada, no próximo item deste capítulo, a mercadoria automóvel e sua categoria de utilitário esportivo. 


\subsection{Sobre o automóvel}

O automóvel como uma mercadoria surgiu no final do século XIX. Era fabricado de forma artesanal, e quem quisesse e pudesse comprar um deveria ir a uma das pouquíssimas oficinas fabricante de máquinas que tinham a tecnologia de construção deste bem e encomendar um. Portanto, não existiam nessa época as montadoras, tampouco as concessionárias.

Por conta disso, os carros eram muito caros, demoravam meses para ficar prontos e era preciso haver sempre por perto um mecânico, que geralmente era também o motorista. Somente a alta sociedade tinha condições de possuir um.

A expansão do mercado de automóveis enfrentava várias dificuldades: falta de capacidade técnica para desenvolver novas tecnologias de produção, falta de garantia referente à qualidade e durabilidade e custo de produção muito elevado. Para superar todas essas dificuldades, Henry Ford criou a produção em massa, com o Ford modelo "T", em 1908. Este carro foi projetado para ser montado baseado na intercambiabilidade de peças, o que permitia a produção seriada; além disso, era fácil de dirigir e reparar, dispensando o motorista mecânico. (WOMACK, 1992)

Com o Ford "T" iniciou-se toda a comercialização de automóveis como é conhecida hoje, e rapidamente foi seguida por outros fabricantes americanos. Nos Estados Unidos da América, com petróleo barato, cidades sendo formadas com infra-estrutura adequada e um modelo mais acessível, o automóvel tornou-se um objeto cobiçado por todos.

Outro fato marcante foi a introdução, por Alfred Sloan, da General Motors, do conceito de carro do ano, que vinha com modificações de design, inclusão de acessórios e novas cores para provocar o interesse dos consumidores de automóveis e induzi-los a trocar de modelo a cada ano.

$\mathrm{Na}$ Europa, o caos econômico, o nacionalismo e o forte apego às tradições da produção artesanal impediram a rápida implantação da produção seriada; a Ford e a GM exportavam carros para o continente europeu, mas o mercado convivia muito com carros artesanais, embora já com boa durabilidade. Sem petróleo, e com cidades antigas de ruas estreitas, a necessidade era de carros menores e mais 
econômicos. Por volta dos anos 1930, a Volkswagem e a Fiat iniciaram planos para uma produção em massa, porém, devido à II Grande Guerra, isto foi postergado e somente após a guerra a Europa entrou na produção em massa com a Volkswagem, a Renault e a Fiat. (WOMACK, 1992)

Por conta das restrições e características acima mencionadas, na Europa sempre predominaram os carros compactos, econômicos, e os agradáveis de dirigir, os esportivos. Já nos Estados Unidos, com petróleo farto, e cidades de largas avenidas, proliferou o modelo de carros grandes e dominadores.

Assim foi até meados da década de 1970, quando aconteceu a primeira crise do petróleo. A alta dos preços da gasolina, problemas econômicos e dificuldades com a mão de obra forçaram a busca por uma alternativa melhor à produção em massa.

Observando os gargalos da produção em massa, Eiji Toyoda e seu Engenheiro Taiichi Ohno criaram um novo modelo de produção que eliminava os estoques, aumentava o rendimento da produção e melhorava o nível de qualidade do produto final. Já na década de 1990 quase todas as montadoras do mundo haviam migrado da produção em massa para a lean production, ou "produção enxuta" (WOMACK, 1992)

No Brasil, a história do automóvel segue de certa forma os mesmos passos descritos acima. Exceto pelo fato de não ter florescido aqui uma fabricação artesanal, e que depois viesse a se tornar uma grande marca brasileira. Ao contrário disso, toda a história do automóvel no Brasil foi escrita por multinacionais americanas, européias e, recentemente, asiáticas.

Em 1919, a Ford instalou, no bairro do Ipiranga, em São Paulo, uma unidade de montagem de carros que vinham já pré-montados dos Estados Unidos da América para finalização aqui no Brasil. Em 1923, a General Motors fez o mesmo, porém para montar apenas veículos comerciais. Em 1930, a frota de veículos no território nacional era de 250 mil unidades, incluindo carros de passeio, caminhões leves e ônibus. Todos para fins urbanos. Marcas como Ford, Lincoln, Buick, Pontiac, Cadillac, e as européias Fiat, Alfa Romeo, Renault e Roll Royce, desfilavam pelas ruas brasileiras. (ANFAVEA, 2008) 
Após a II Guerra Mundial, em 1950, a frota brasileira era de 500 veículos. O Brasil era um ator sem importância, mas no mundo dava-se o auge da produção em massa, gerando um excesso de oferta, e, conseqüentemente, um interesse das grandes multinacionais em expandir-se para novos mercados.

O Brasil, após os esforços do governo Vargas em instalar uma indústria de base, constituiu, em 1956, o GEIA - Grupo Executivo da Indústria Automobilística, que tinha como objetivo trazer grandes montadoras para iniciar a fabricação de automóveis no território brasileiro. O automóvel inteiramente fabricado no Brasil era considerado um "passaporte para a modernidade". (ARBIX e ZILBOVICIUS, 1997, 7)

Foram feitas várias propostas, inicialmente para as americanas Ford e General Motors, que, embora apresentassem planos, este se restringiram à montagem de caminhões e ônibus, pois tinham como prioridade investir no mercado europeu. Mas a Volkswagem veio com um plano ousado e fez na fábrica de São Bernardo do Campo, no estado de São Paulo, a sua maior fábrica fora da Alemanha. Aqui, com o "Fusca", ela conseguiu um grande sucesso de vendas, a ponto de, em 1968, obter dois terços da produção total brasileira. Era o ingresso do Brasil na produção em massa. (ANFAVEA, 2008)

Com a expansão do mercado brasileiro, a Ford e a General Motors decidem também iniciar a produção de automóveis, além da produção de ônibus e caminhões. Ambas entraram na faixa de luxo; a primeira com o Galaxie, em 1967, com design americano, e a segunda com o Opala, em 1969, com design alemão de sua subsidiária, a Opel. Em 1973, a italiana Fiat vem para o Brasil e se instala em Betim, Minas Gerais, para fabricar o compacto Fiat 147, para distribuição no mercado brasileiro, mas também para exportação.

A crise do petróleo atingiu em cheio o mercado brasileiro, obrigando os fabricantes a ofertarem carros mais econômicos. A Volkswagem já tinha esta tradição, e a General Motors lança o Chevette. Já a Ford, que não possuía um produto adequado, no inicio da década de 1980 se associa à Volkswagem e juntas formam a Autolatina.

Com as sucessivas crises econômicas, inflação galopante, custos de produção elevados, problemas sindicais no ABC paulista, baixo nível de automação, barreiras à importações e nenhuma tecnologia eletrônica, devido à reserva de 
mercado de informática, o Brasil, em termos de industria automobilística, era um país atrasado, com produtos defasados.

Isto ficou evidente quando o Presidente Collor, que chamou os automóveis brasileiros de "carroças", liberou as importações, revelando assim para o público as diferenças tecnológicas entre os carros nacionais e os importados, como os franceses, Citroën, Peugeot, Renault, entre outros de demais nacionalidades. O ciclo de vida médio de um carro no Brasil, nessa época, era de 15 anos, enquanto que no restante do mundo era de somente quatro (WOMACK, 1992)

Com o advento do Plano Real, em 1994, trazendo estabilidade à economia, aliada ao já em vigor acordo entre fabricas, concessionárias e governo, para instituir o carro popular, o mercado brasileiro de automóveis começa a se desenvolver com força, fazendo com que as montadoras aqui instaladas reformassem suas fábricas e construíssem novas unidades já com a metodologia de produção enxuta. Além disso, novos entrantes se instalaram no território nacional. O Brasil saiu das suas quatro montadoras, em 1994, para já, em 2000, possuir doze. 


\subsection{Os significados do automóvel no Brasil}

O automóvel foi talvez a invenção e a mercadoria mais impactante no cotidiano urbano. Modificou cidades, criou oportunidades de trabalho, impulsionou o desenvolvimento tecnológico, estabeleceu novos meios de lazer, criou todo um sistema de suprimento de peças, serviços e acessórios e desenvolveu a economia de certas regiões nas quais foram instaladas fábricas; enfim, desde sua implantação, ele vem modificando o mundo.

Por outro lado, todo o esforço para se fabricar um automóvel vem gerando um custo ambiental e social muito grande. Poluição, impactos no aquecimento global, congestionamentos gigantes, acidentes, etc. vêm prejudicando a qualidade de vida nos centros urbanos e colocando em risco nosso ecossistema. Mas, apesar de tudo, ele ainda é apontado como um dos principais objetos de desejo, competindo com a casa própria e o sonho do próprio negócio.

Amenizar os problemas causados pelo automóvel não é somente responsabilidade dos fabricantes, desenvolvendo carros menos poluentes, e do poder público, investindo na melhoria do tráfego; é também responsabilidade do consumidor, dirigindo com cautela, responsabilidade e efetuando todas as manutenções recomendadas pelas montadoras. Em médio prazo parece não haver uma mobilização efetiva destas três partes na direção de um automóvel socialmente responsável. Apesar dos esforços das montadoras na busca por soluções, parece que a velocidade dos efeitos no meio ambiente vem sobrepujando estes esforços, colocando o automóvel como o grande vilão da história. $E$, sem dúvida, esses fatores podem colocar em risco o sistema de discurso dessa mercadoria, alterando seus significados e sua mitologia.

O objetivo aqui é tentar delinear, de forma resumida, numa ordem cronológica os principais significados do automóvel no Brasil. Desde já fica registrada uma falta de estudos específicos sobre o assunto, bem como a ausência de bibliografia e pesquisas. O que, por outro lado, pode servir de incentivo a futuros pesquisadores. Os pontos aqui levantados têm como base alguma bibliografia estrangeira, com adaptações e observações da vida prática deste pesquisador, servindo a esta estudo como pontos de reflexão. 
O inicio da relação automóvel e consumidor foi marcado por muita aventura. Santos Dumont foi um dos pioneiros proprietários de automóveis no Brasil. Ele possuía um Peugeot, construído em 1891 (WOMACK, 1992, 311) Nessa época, sua viagem do Rio de Janeiro a Petrópolis, ou a subida ao Corcovado, por certo causava muita sensação. Dirigir era um esporte nobre para a elite econômica e cultural daqueles tempos. O contexto machista da época, as condições das estradas, a necessidade de contar sempre com um mecânico, as possíveis dificuldades de dirigir exigindo certa disposição física fizeram do automóvel um objeto para homens. Para estes, era um símbolo de grande poder e trazia em si os emblemas de uma época de pioneirismo, grandes invenções, novas máquinas, enfim, um ícone da modernidade.

Nas primeiras décadas do século XX, devido ao desenvolvimento tardio da indústria automobilística no Brasil, a decorrente importação de automóveis deixava o mercado brasileiro ainda restrito às elites. Porém, com a melhoria das condições de rodagem nas cidades e a abertura de estradas o automóvel começava a ganhar a cena perante todas as pessoas, causando inveja, curiosidade e muita admiração. $O$ carro passa a adquirir um significado de muito status.

A partir do final da década de 1950, o Brasil passa a produzir carros, emprestando novos significados a esta mercadoria. Em novembro de 1956, sai da fábrica da Vemag, na cidade de São Paulo, o primeiro carro fabricado em território nacional, o DKW-Vemag.; na seqüência, em 1959, são lançados o "Fusca" e o Simca Chambord; em 1961, surge o primeiro esportivo, o Willys Interlagos; com muito 'frisson' chega, em 1966, o Ford Galaxie, cujo modelo ainda estava em produção nos Estados Unidos; em 1969 aparece o Chevrolet Opala; já em 1973 temos o primeiro carro projetado no Brasil, a Volkswagen Brasília; por fim, o primeiro Fiat sai em 1976. E assim pontuavam as novidades, para um consumidor ávido por novos automóveis. (ANFAVEA 2008)

Nas décadas de 1960 e 1970, o consumidor já tinha à disposição carros de luxo, compactos, peruas, sedans e esportivos em diversas faixas de preço, sendo o mais acessível deles o "Fusca". Apesar de muitas mulheres se aventurarem a dirigir carros, este continuava a ser exclusivamente do mundo masculino, mesmo na Europa, segundo Baudrillard, em seu livro "O sistema dos objetos", escrito em 1968, que diz: "o veículo permanece, com efeito, freqüentemente apanágio do homem. 
"Papai tem o seu Peugeot, Mamãe tem seus Peugeots" diz um anúncio. Para o homem, o carro, para a mulher, o liquidificador, o moedor de café, etc." (BAUDRILLARD, 2000, 76).

O início da fabricação do automóvel levantou o orgulho nacional. O Brasil estava se desenvolvendo, e junto vieram novas obras, novas estradas, e os signos do progresso, da modernidade, do arrojo eram transferidos para os carros. Tirar a carta de motorista e possuir um carro era também se inserir nesse mundo moderno.

Na música, Roberto Carlos agregava ainda mais apelo emocional com várias canções sobre o tema automobilístico, O calhambeque, As curvas da estrada de Santos, as quais, juntamente com seus filmes e inúmeros outros vindos de fora, como Juventude Transviada, 24 horas de Le Mans, criaram uma áurea de esportividade, prestígio e poder, velocidade e rebeldia.

A partir da década de 1990, após o Plano Real, com uma situação econômica estável, novos significados foram incorporados. Importações liberadas, montadoras tradicionais procurando atualizar seus produtos, entrada de novas montadoras, consolidação do programa do carro popular reforçaram ainda mais o caráter de status e poder. Porém, um dos fatores mais importantes foi o crescimento do público feminino.

O carro no final do século $X X$ já havia deixado de ser algo exclusivo do universo masculino para passar também a fazer parte do mundo feminino. Ambos, homens e mulheres, têm a necessidade da mobilidade, mas se observam atitudes muito diferentes entre o motorista homem e a motorista mulher, principalmente na experiência da mobilidade.

O automóvel dá ao usuário uma condição de estar num espaço privado se deslocando num espaço público. Essa simultaneidade sugere que o carro é um prolongamento da casa, do seu ambiente privado que se expande nas vias públicas. "A cotidianidade privada toma com o veículo as dimensões do mundo sem deixar de ser cotidianidade" (BAUDRILLARD, 2000: 74)

Essa possibilidade de movimentar-se dentro de um espaço privado, protegido por um invólucro de metal e vidro que resguarda sua identidade, dá ao motorista uma impressão de ainda estar na intimidade do lar, porém em movimento, podendo usufruir do prazer da velocidade e da mobilidade num "metabolismo acelerado no 
tempo e no espaço". O Carro constitui, assim, "o centro de uma subjetividade nova cuja circunferência não se acha em parte alguma enquanto a subjetividade do mundo doméstico é circunscrita" (BAUDRILLARD, 2000: 76)

Assim, o comportamento e a atitude de homens e mulheres ao volante seguem os padrões culturais de quando estes estão em seu ambiente privado. Ou seja, o homem, supostamente o dono da casa, defende seu território de forma muito mais viril com buzinadas e palavrões, enquanto as mulheres, ou seja, supostamente quem cuida da casa, não têm essa necessidade agressiva, sendo muito mais cuidadosas. Isto se reflete até mesmo nas avaliações das empresas seguradoras brasileiras, que cobram um valor mais baixo das mulheres por estas serem mais cuidadosas e se envolverem menos em acidentes. A atitude masculina ao volante também se relaciona com a idade, por uma série de fatores culturais, psicológicos e até fisiológicos: quanto mais jovens os motoristas, mais arrojo, mais acidentes também. Ver tabela 1.

Tabela 1

\begin{tabular}{|l|c|c|}
\hline \multicolumn{2}{|c|}{ Índice de Sinistros/Prêmio por Idade / Sexo 1․ Semestre 2007 } \\
\hline & \multicolumn{2}{|c|}{ Sinistro / Prêmio } \\
\hline Faixa de Idade & Masculino & Feminino \\
\hline Entre 18 e 25 anos & $84,26 \%$ & $58,77 \%$ \\
\hline Entre 26 e 35 anos & $85,65 \%$ & $65,56 \%$ \\
\hline Entre 36 e 45 anos & $67,91 \%$ & $63,09 \%$ \\
\hline Entre 46 e 55 anos & $65,48 \%$ & $69,71 \%$ \\
\hline Maior que 55 anos & $43,35 \%$ & $46,03 \%$ \\
\hline
\end{tabular}

Fonte: susep em http://www.susep.gov.br/menuestatistica/autoseg/resp menu1.asp

Outro aspecto observável é o enfoque que os vendedores de automóveis dão com relação ao gênero de seus potenciais compradores. Como parte do treinamento 
de vendas, os vendedores elaboram perfis de compradores, baseados em experiências acumuladas pelo setor de varejo de automóveis.

Neste sentido, homens são atraídos pela potência do motor, pelo design, mas particularmente pela capacidade de o automóvel lhe dar um estilo viril, atraente ao sexo oposto. Ao dirigir o carro, ele mostra como sabe dominar, conduzir aquilo que seria uma mulher ideal. "O automóvel, estendendo o poder do homem, posiciona-se acima da mulher: mais fiel, manobrável, estável, e, sobretudo, mais cooperante com os seus desejos e objetivos" (ARAÚJO, 2004)

Os atributos de virilidade, velocidade e potência estão sempre presentes na publicidade de automóveis, reforçando o processo de identificação masculina com este objeto. Já as mulheres são atraídas pelas características funcionais do automóvel nos quesitos; segurança; facilidade de estacionar; "porta-trecos", conforto interior do carro, confiabilidade mecânica e, mais recentemente, estar numa posição mais elevada. Observa-se que o carro, atualmente, para a mulher, é um símbolo de independência e de liberdade, mas com segurança.

Conforme se viu, então, o automóvel, como também outras mercadorias, apresenta significados diferentes para cada gênero. A publicidade, atendendo às necessidades das montadoras, elabora discursos para atrair homens e mulheres, reforçando os significados e simbolismos valorizados por cada sexo.

Um desafio para os publicitários foi comunicar o "carro para a família". Esta categoria cresceu muito no mercado brasileiro, cujos lares possuíam somente um carro, e a influência da mulher no processo de compra, apesar de sempre efetiva, tinha uma postura mais passiva, contribuindo com o homem.

Hoje, além de ter ser próprio carro, a opinião da mulher é decisiva na escolha de um modelo para a família, conforme revelam pesquisas das montadoras, segundo as quais mais de $60 \%$ das aquisições dos carros de família são fortemente influenciadas pela opinião feminina. Assim, o carro de família procura satisfazer tanto os desejos masculinos como os femininos, oferecendo, além da potência, espaço e conforto, possibilidades para acomodar cadeirinhas e carrinhos de bebê, sempre com muita segurança para todos. A comunicação publicitária do carro de família inventou um novo homem, o bem sucedido, que participa das atribuições 
domésticas e da educação dos filhos. Esse novo homem desfruta da potência e da virilidade, mas quer compartilhar seus momentos com sua família.

A compra de um carro é uma experiência impar, mas a compra de um novo, zero-quilômetro, chega a ser um acontecimento marcante. Retirar o automóvel na concessionária é um momento mágico. Sentir o cheirinho de novo é um afrodisíaco para o proprietário, retirar os plásticos dos bancos, revelando sua textura, é como uma primeira noite de núpcias. Dar as primeiras voltas com o carro, exibindo-o para vizinhos, amigos e parentes, traz uma sensação de conquista ao seu proprietário.

A experiência de dirigir envolve um prazer muito grande; dominar uma máquina e colocá-la em movimento, sentir o contato do material do volante nas mãos, acionar os comandos, mudar as marchas (em caso de carros com transmissão mecânica), enfim, a interação do corpo humano com um corpo metálico para exercer uma mobilidade é uma experiência marcante que explica o termo do cotidiano: prazer de dirigir. Por outro lado, dirigir também envolve uma prática social, com responsabilidade e obediência às leis de trânsito.

Enfim, o automóvel, no Brasil, traz em si significados emocionais que orbitam entre o poder, o status, o prestígio, a virilidade, a juventude, a liberdade, a segurança, a esportividade, a aventura e o prazer da mobilidade, entre outros. Do lado racional, encontram-se significados relativos à mobilidade, como velocidade, espaço interno, confiabilidade mecânica, capacidade de passageiros e carga, custo / benefício, praticidade, preço e, por fim, ainda que muito restrito a camadas mais críticas da população dos grandes centros urbanos brasileiros, temos os predicados relativos aos impactos negativos do automóvel no meio ambiente.

O lado negativo do automóvel sempre existiu. No começo, muito ligado aos acidentes, fato que obrigou as montadoras a desenvolverem sistemas de segurança que evitam acidentes, chamados de segurança ativa, a saber, sistemas de freios e suspensão controlados eletronicamente e os sistemas que minimizam os efeitos dos acidentes, chamados de segurança passiva, as bolsas infláveis, as barras protetoras e reforços para proteger os passageiros.

Depois, com o surgimento das grandes metrópoles, os congestionamentos, a poluição e a transformação urbana para adequar as cidades às necessidades de rodagem e estacionamentos, foram agregados mais predicados negativos aos 
automóveis. A crise do petróleo, iniciada nos anos 70 do século passado, e retornada com maior intensidade com as guerras e conflitos no Oriente Médio, neste início de século, vem contribuindo para redefinir modelos exageradamente grandes e excessivamente consumidores de gasolina, tornando-os fora de moda.

Recentemente, com as evidências dos efeitos do aquecimento global, o carro ganha novamente o status de vilão, obrigando as montadoras a iniciarem uma corrida intensa para desenvolver um automóvel sustentável, movido a combustíveis alternativos, evitando assim que esta mercadoria seja o novo cigarro do mundo, rejeitado e discriminado na sociedade.

Esses efeitos já são sentidos há algum tempo na Europa, e agora também são nítidos nos Estados Unidos e Japão. Os grandes utilitários esportivos, como o Hummer, modelo nascido para operações militares no deserto e que ganhou notoriedade por ser o carro do astro e governador da Califórnia, Arnold Schwartznegger, estão em declínio, a ponto de serem hostilizados em vias públicas, devido ao excesso de consumo de combustível e suas altas taxas de emissão de poluentes.

No Brasil, até mesmo pelas dificuldades econômicas da população, os carros grandes nunca dominaram a paisagem urbana. Os ventos da poluição e do aquecimento global parecem estar turvando muito pouco a visão dos consumidores brasileiros, mesmo porque a frota brasileira tem uma grande parcela de carros que podem usar álcool, combustível menos poluidor e menos emissor de dióxido de carbono, responsável pelo efeito estufa. Aqui o problema mesmo, por enquanto, é o trânsito das grandes capitais. Mas é inegável que, em curto espaço de tempo, os brasileiros também serão impactados pelos efeitos que os automóveis causam ao meio ambiente, de forma que os significados relativos aos prazeres da mobilidade comecem a sofrer alterações.

Estaria então a cultura automobilística em declínio? Parece cedo para responder, embora em reportagem da Revista Exame o diretor mundial de planejamento da Nissan, o americano Tom Lane, tenha declarado que a vida sobre quatro rodas está perdendo espaço para a internet e os telefones celulares. "Os japoneses estão se desinteressando pelos carros. Os americanos seguem numa mesma direção. Nosso desafio, no futuro, é oferecer algo mais interessante" (TEIXEIRA, 2008). Há que se considerar que nos países em desenvolvimento, como 
Índia e China, o carro é, de certa forma, uma novidade, e, como no Brasil, ainda um atestado de cidadania. Mas até quando?

Observando-se a movimentação dos fabricantes, está evidente que estes não vão esperar por uma resposta. O salão de Detroit de janeiro de 2008 estava repleto de modelos híbridos, como o Volt, da GM, e o Escape, da Ford, bem como os carros movidos a célula de combustível a hidrogênio, que emitem vapor de água na atmosfera, mas que ainda estão longe de serem economicamente viáveis. Novos modelos compactos, novas alternativas de combustíveis, novas atitudes no trânsito, tudo isso, sem dúvida nenhuma, vai alterar a mitologia da máquina que mudou e continua a mudar o mundo, o automóvel. 


\section{SISTEMA DE VALORIZAÇÃO DO CONSUMO DE AUTOMÓVEIS UTILITÁRIOS ESPORTIVOS NO BRASIL}

Cada modelo de carroceria de veículo, hatchback, sedan, perua, pick-up, monovolume ou utilitário esportivo, segue uma proposta de funcionalidade. $\mathrm{O}$ design da carroceria, além dos atributos estéticos, atende uma função específica de acordo com a necessidade do consumidor. Para a família, peruas, para os jovens, os hatchs, para quem necessita de dirigir fora da estrada, os utilitários esportivos. Enfim, existe uma configuração do desenho e construção do automóvel para contemplar as mais diversas necessidades de mobilidade.

Embora a intenção na concepção destes modelos variados seja satisfazer necessidades de usos, por meio de funcionalidades específicas, a escolha por determinado modelo não segue bem esta regra. Carros modelo hatchbacks esportivos, com grande potência de motor, são comprados e nunca utilizados na sua plenitude; carros esportivos utilitários, projetados para atuar fora-de-estrada, são comprados por consumidores que pretendem circular somente em áreas urbanas.

Mais intrigante ainda é que a escolha, por vezes, também não segue os atributos funcionais dos veículos. Explicando melhor, carros são projetados para ter um design de fora-de-estrada, ou esportivo, mas na realidade não cumprem estas funções. No caso do EcoSport, se submetido a rodar em áreas sem pavimentação, com buracos e lama, provavelmente terá seu desempenho prejudicado pela falta das capacidades funcionais para um veículo com este propósito.

No entanto, o EcoSport é um carro de sucesso, devido ao seu design, que sugere ser um carro fora-de-estrada. $\mathrm{O}$ mesmo acontece com carro um que se denomina esportivo, como o caso do Golf, o qual, no entanto, tem uma motorização de 1.6 cilindradas, com uma velocidade final próxima de $160 \mathrm{Km} / \mathrm{h}$, muito aquém do que se exige de um carro esportivo, que pode atingir até $300 \mathrm{Km} / \mathrm{h}$.

A atratividade destes modelos é baseada em dois fatores. $O$ primeiro diz respeito à forma, uma vez que muitos consumidores tendem a valorizá-la mais que as próprias funcionalidades do veículo. $O$ segundo fator refere-se à sua utilização. $A$ maioria dos consumidores raramente vai exigir desses modelos as funcionalidades que sua forma sugere. Ou seja, o consumidor que compra um EcoSport, cuja forma 
é de um utilitário esportivo, não necessita das funcionalidades que um verdadeiro fora-de-estrada pode oferecer, mas se encanta com o design e com os significados que ele traz em si.

Atendo-se especificamente aos utilitários esportivos, quais são os significados que este modelo de automóvel possui? E como eles atraem os seus públicos? Para responder a estas questões será necessária uma classificação sob o ponto de vista da valorização do consumo de automóveis elaborada por Jean-Marie Floch. 


\subsection{Mercado brasileiro dos utilitários esportivos}

A categoria de utilitários esportivos - tradução livre do inglês Sport Utility Vehicle, ou SUV -- surgiu nos Estados Unidos em 1983, com o lançamento do Jeep Cherokee. Desde então, este tipo de veículo vem ganhando as ruas do mundo todo. Inicialmente os utilitários esportivos eram muito criticados na Europa pelo seu comportamento dinâmico, muito inferior ao de um automóvel, e pelo alto consumo de combustível. Contudo, este modelo evoluiu muito tecnologicamente, tornando-se mais econômico, mais confortável, mais estável e mais compacto. Hoje, quase todas as grandes montadoras, incluindo as mais tradicionais marcas européias, como a Mercedes-Benz, com a Classe M, a BMW, com a X5 e a Porsche, com a Cayene, produzem veículos nesta categoria.

Originalmente a definição de um Veículo Utilitário Esportivo, ou, para efeito desta pesquisa, somente VUE, engloba ser um carro similar, em termos de conforto, a uma perua, porém construído sobre o chassi de uma pick-up leve, constituindo-se assim num carro confortável, mas robusto, com boa capacidade de carga e bastante espaço para passageiros. Geralmente este tipo de veículo possui tração nas quatro rodas, comumente chamada de $4 \times 4$ (quatro por quatro), que contribui para o desempenho deste modelo em condições em que o terreno não é pavimentado. Mas há também versões sem esta característica, uma vez que rodar fora de estrada não é uma função primordial deste tipo de carro.

Já em meados da primeira década deste século, este tipo de carro sofreu várias críticas pelo alto consumo de combustível e pelos altos índices de emissão de poluentes. Desde então as montadoras vêm substituindo os chassi desta categoria por chassi oriundo de carros de passeio mais leves e menos poluentes. Estes novos utilitários esportivos também são chamados de crossover.

No Brasil, devido ao sucesso que este tipo de construção vem conquistando, as montadoras oferecem versões mais baratas, que, apesar de aparentarem um modelo desta categoria, não apresentam características funcionais que permitam trafegar fora de estrada. O melhor exemplo disso é o EcoSport, seguido de versões "camufladas" de utilitários esportivos, como o Crossfox e a Palio Adventure. 
De acordo com a segmentação proposta pela ANFAVEA - ASSOCIAÇÃO NACIONAL DOS FABRICANTES DE VEÍCULOS AUTOMOTIVOS - os veículos utilitários esportivos estão no segmento Recreação (Recreation) dentro deste há uma sub-segmentação em:

- Utilitários pequenos (sporty utility small) os veículos comercializados no Brasil os seguintes:

- Chrysler PT Cruise

○ Ford EcoSport

- General Motors Tracker

- Hyundai Tucson

- Kia Sportage

- Mitsubishi Pajero TR4

- Volkswagem Crossfox

- Utilitários médios ( sporty utility médium)

- Chrysler Cherokee Sport

- Chrysler Wrangler

- General Motors Blazer

- Honda CR-V

- Hyundai Santa Fé

- Kia Sorento

- Land Rover Freelander

- Mitsubishi Airtrek

- Mitsubishi Pajero Sport

- Nissan X-Terra

- Nissan XTRAIL

- Subaru Forester 

○ Toyota RAV4
○ Troller T4

- Utilitários esportivos premio (sporty utility premium)

- BMW série X5

- BMW série X3

- Chrysler Grand Cherokee

- General Motors Hummer H2

- General Motors Hummer H3

- Hyundai Veracruz

- Infinity FX 35

- Land Rover Discovery

- Land Rover Range Rover

- Mercedes Benz Classe M

- Mercedes Benz Classe G

- Mitsubishi Outlander

- Mitsubishi Pajero Full

- Nissan Pathfinder

- Porsche Cayenne

○ Toyota Hilux SW4

- Toyota Land Cruiser

- Toyota Lexus

○ Volkswagen Touareg

- Volvo XC90

- Volvo XC70

A Palio Adventure, embora com alguma aparência de utilitário esportivo, é classificada como perua compacta. 
Como em geral, dentro do segmento de recreação verifica-se uma forte relação entre o preço e o volume de vendas conforme tabela abaixo na qual se têm os cinco modelos mais vendidos em 2007.

Tabela II

MARCA
FORD
VOLKSWAGEN
HYUNDAI
MITSUBISHI
TOYOTA

MODELO ECOSPORT CROSSFOX TUCSON PAJERO TR4 HILUX SW4
VENDAS 2007 PREÇO (R\$)

$47961 \quad 50.000,00$

$27317 \quad 45.000,00$

$1265990.000,00$

$7692 \quad 76.000,00$

$7216 \quad 153.000,00$

Fica claro que o preço é um fator determinante na escolha de um modelo, o importante é o fato de o EcoSport vender quase o dobro do Crossfox estando na mesma faixa de preço. Na tabela abaixo, classificada por vendas, é possível verificar a superioridade na preferência pelo EcoSport sobre os outros tipos de veículos na mesma faixa de preço.

Tabela III

SUB SEGMENTO

VUE PEQUENO

MINIVAN

COMPACTA

MINIVAN

COMPACTA

HATCH PEQUENO

PERUA COMPACTA

HATCH COMPACTO

HATCH COMPACTO

$\begin{array}{llrr}\text { MARCA } & \text { MODELO } & \text { VENDAS 2007 } & \text { PREÇO (R\$) } \\ \text { FORD } & \text { ECOSPORT } & 47961 & 50.000,00 \\ & & & \\ \text { HONDA } & \text { FIT } & 35395 & 50.000,00 \\ & & & \\ \text { CHEVROLET } & \text { MERIVA } & 23150 & 52.000,00 \\ \text { VOLKSWAGEM } & \text { POLO } & 22725 & 46.000,00 \\ \text { PEUGEOT } & \text { SW } & 19285 & 48.000,00 \\ \text { VOLKSWAGEM } & \text { GOLF } & 14050 & 49.000,00 \\ \text { FIAT } & \text { STILO } & 13413 & 50.000,00\end{array}$

\section{EcoSport}

O EcoSport é produzido no Brasil sobre a plataforma do Fiesta. Foi lançado em 2003 e desde então vem apresentando um relativo sucesso de vendas. Seu auge foi em 2005 onde alcançou 46084 unidades vendidas conquistando uma participação do mercado total de automóveis na ordem de 3,6\%. Nos anos de 2006 e 2007, embora mantivesse os mesmo patamares de vendas iniciou uma queda na 
participação de mercado devido ao desgaste natural, seguindo uma curva comum a outros modelos em termos de ciclo de vida.

No final de 2007 a Ford remodelou o EcoSport tornando muito mais atraente, com isto já é possível sentir uma recuperação nas vendas, mas devido a vários outros entrantes no mercado, como o Hyundai Tucson, muito mais robusto e com mais funcionalidades pertinentes a proposta de um utilitário esportivo, o EcoSport não apresenta mais uma participação de mercado como a obtida em 2005.

\section{Tabela IV}

Vendas anuais do Ford EcoSport

$\begin{array}{lrrrrrr} & 2003 & 2004 & 2005 & 2006 & 2007 & 2008 \text { (JUL) } \\ \text { ECOSPORT } & 29081 & 41329 & 46084 & 44114 & 45631 & 29289\end{array}$

Fonte: ANFAVEA, 2008

Após sua remodelação em 2007 o EcoSport apresenta um início de recuperação de vendas que vem se confirmando até a metade de 2008, porém conforme quadro abaixo sua participação de mercado vem caindo devido o exposto acima.

Quadro XIII

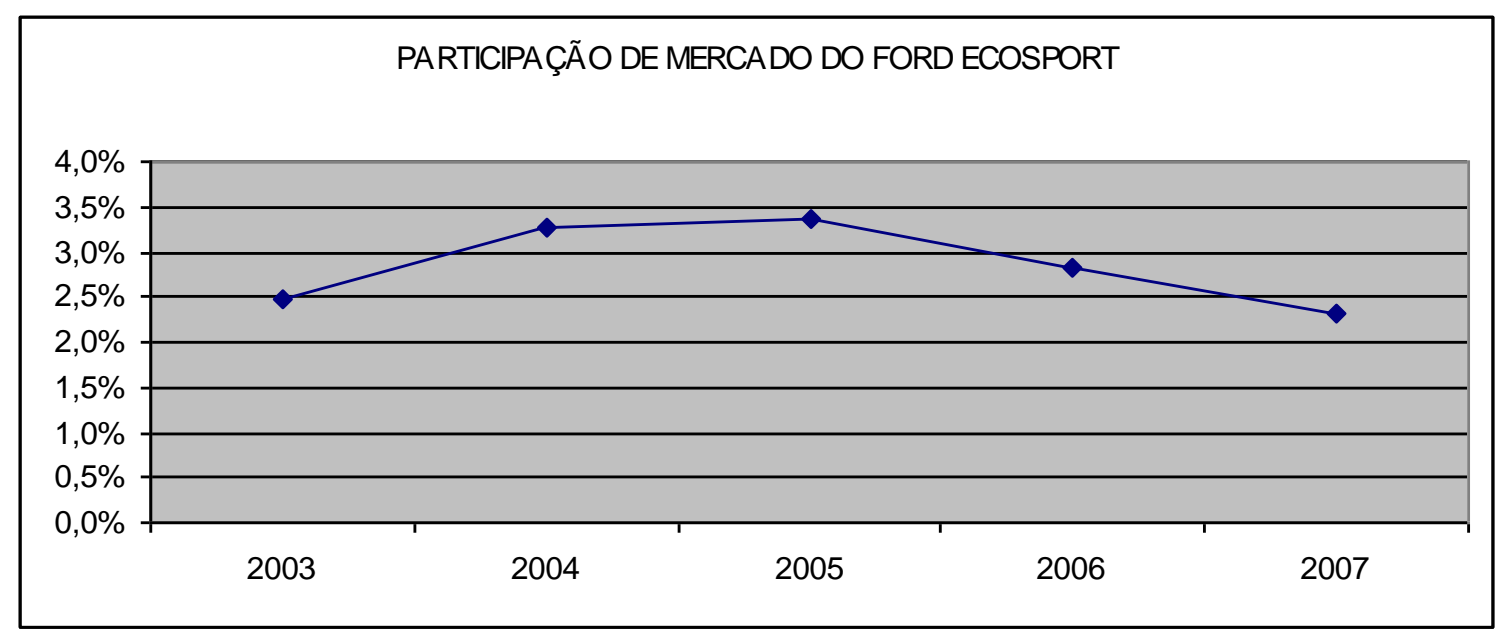




\section{2. Axiologia do consumo de veículos utilitários esportivos}

Em sua axiologia do consumo, Floch chama os valores funcionais de um automóvel como, dirigibilidade, confiabilidade mecânica, tamanho do porta-malas, capacidade de frenagem, motorização e conforto para os passageiros de "valores de uso". Por outro lado, os valores emocionais atribuídos pelo proprietário, fruto do discurso desta mercadoria e de suas aspirações e identidade, como status social, virilidade, ou feminilidade, poder, aventura, beleza, etc. ele chama de "valores de base" (FLOCH, 1993: 145).

Funcionalidade versus identidade, valores de uso versus valores de base, razão versus emoção, necessidade versus desejo. Todos são termos que se alinham em cada extremidade de um eixo semântico em uma situação de contrariedade muito explorada na publicidade de automóveis, como por exemplo, a do RAV4, utilitário esportivo da Toyota que diz: "O design é para fazer inveja. A agilidade é para você fugir dela". (Anexo IV)

Eixo semântico

Valor de uso

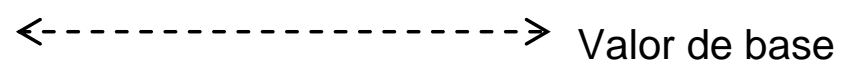

Relação de contrariedade

Nesta peça publicitária para revista o apelo racional das funcionalidades do carro, agilidade, dirigibilidade, velocidade, aceleração e o apelo emocional no desejo de se destacar, de ter alto status, de mostrar poder ficam bem evidentes. Embora dispostos como contrários, estes valores expressam uma relação entre eles. Assim, o Honda RAV4 atende às necessidades funcionais de mobilidade, oferecendo uma razão de compra para o público e ao mesmo tempo sugere atender a desejos íntimos, por vezes desconhecidos pelo consumidor, que o movem para a compra.

Como visto no capítulo sobre posicionamento semiótico de marca, evoluindo o eixo semântico entre os valores de uso e valores de base projetam-se num 
quadrado semiótico os quatro tipos gerais de valorização para o automóvel, "valorização prática", "valorização utópica", "valorização lúdica" e "valorização crítica" (FLOCH, 1993: 148)

Valorizações no quadrado semiótico

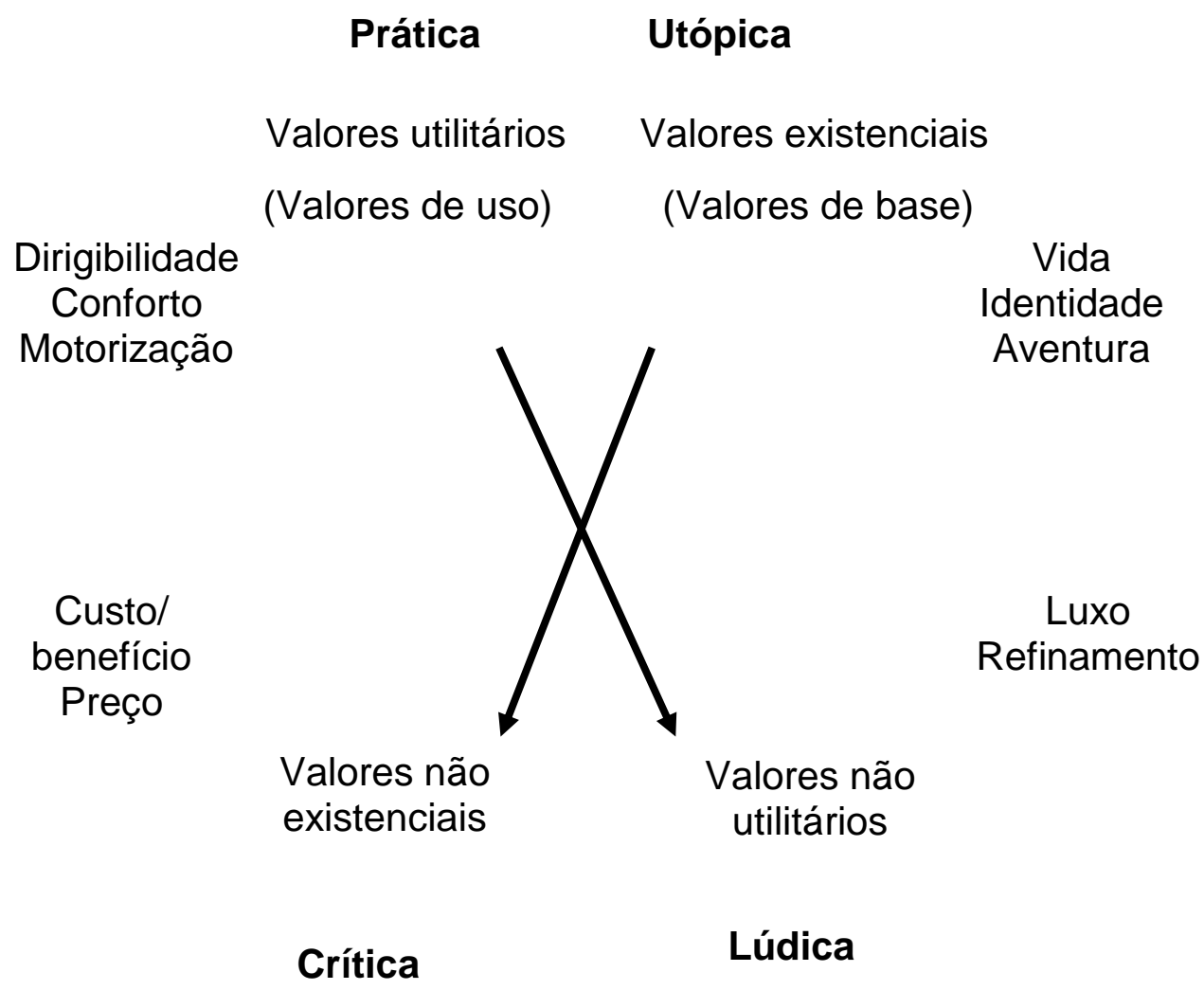

Fonte: FLOCH 1993:148

\section{Valorização prática}

A valorização prática refere-se aos valores de uso, corresponde às funcionalidades do automóvel, a dirigibilidade, os freios, a motorização, os componentes internos, a tecnologia, o design quando este está ligado à funcionalidade, ex. um carro esportivo deve ter um desenho mais aerodinâmico possível, no caso dos utilitários esportivos o carro deve ter um desenho robusto e 
com a suspensão elevada para trafegar em terrenos sem pavimentação. O aspecto racional fala mais alto.

Os consumidores que valorizam mais os aspectos práticos dos utilitários esportivos procuram os que realmente oferecem as funcionalidades como suspensão elevada e projetada para todos os terrenos, tração nas quatro rodas, freios especiais, carroceria resistente à torção, entre outros atributos tecnológicos para este cliente poder usufruir da mobilidade fora-de-estrada. É o caso da Pick-up cabine dupla Chevrolet S10 ou Ford Ranger, cujo design já está desgastado mas sua funcionalidade é uma das melhores do mercado. Sua aceitação vem mais das áreas rurais

\section{Valorização utópica}

A valorização utópica refere-se aos valores de base, esta ligada ao lado emocional do consumidor de como ele se identifica ou aspira se identificar, deve refletir um estilo de vida desejado, no caso dos utilitários esportivos reflete a aventura, um sonho de liberdade fora da loucura das grandes cidades, o contato com a natureza, mesmo que o consumidor não tenha a oportunidade de se aventurar, pois ele busca um discurso para si, uma identidade.

Para esta categoria de valorização, o mais importante é a aparência de utilitário esportivo, contrariando a valorização prática, mesmo porque para expandir a base de clientes são oferecidos modelos que contam com a aparência, mas não com as funcionalidades. É o caso do EcoSport que pouco oferece em termos de funcionalidades mas apresenta um design muito atraente e convincente de utlitário esportivo.

\section{Valorização lúdica}

A valorização lúdica diz respeito aos valores contraditórios aos práticos, negando-os. Esta valorização considera o luxo, o status, o refinamento, ela complementa a valorização utópica, pois também está ligada ao lado emocional. Para esta categoria o mais importante, em termos de automóveis é a sua marca e todo o simbolismo de ser exclusivo e poderoso. 
Os seus consumidores jogam com a mercadoria para satisfazer seus desejos mostrar a todos que chegou lá. Aqui entra as grandes marcas e seus modelos de utilitários esportivos, como a Porch Cayene, a BMW X4, a Mercedes-Bens ML, que embora ofereçam muita tecnologia em termos de funcionalidade seus compradores não pretendem sair das estradas ou das cidades, ou seja, provavelmente não vão usá-las.

\section{Valorização crítica}

A valorização crítica é uma contradição dos valores de base. Complementa os valores práticos, pois está do lado racional do eixo semântico, mas nega os valores existenciais. Para este consumidor o que vale é o custo / benefício. O automóvel deve apresentar uma qualidade satisfatória pelo menor preço possível. É aquele que sempre busca uma melhor oferta e sua realização é fazer um bom negócio. 0 consumidor desta categoria de valorização vai buscar entre a Chevrolet S10 ou a Ford Ranger a que lhe oferecer mais vantagens financeiras.

Quando esta ferramenta semiótica, o quadrado semiótico aplicado às valorizações do consumo, começa a ser utilizada verifica-se que quase não existe um consumidor que só valorize os aspectos utópicos, ou práticos, etc. Observa-se uma dinâmica que se alterna entre razão de compra, impulsionada pelas características funcionais ou pela ocasião de uma boa oferta, e as emoções subjacentes ao consciente que impulsionam o consumidor para a mercadoria.

Neste jogo entre funcionalidades e desejos, o lado emocional parece falar mais alto, pois é nítido o poder das marcas cuja imagem está associada a valores utópicos e lúdicos. Neste sentido será apresentado abaixo um levantamento dos significados emocionais dos automóveis utilitários esportivos. 


\subsection{O discurso dos utilitários esportivos na publicidade brasileira}

Como referido anteriormente, o automóvel desperta nos seus proprietários um entusiasmo muito grande, devido às funcionalidades, emoções e sensações da mobilidade. Vários significados Ihe são atribuídos, em boa parte frutos de uma mítica construída pelo discurso da publicidade de automóveis ao longo dos anos.

No caso dos utilitários esportivos, além de toda essa carga de significados própria do automóvel, outras tantas lhe são conferidas que vão muito além das utilidades propostas por este tipo de carro. Embora o nome de sua categoria faça uma referência explícita aos aspectos funcionais, "utilitários", em geral estas funções dificilmente são colocadas a serviço do condutor. Os utilitários esportivos, com ou sem atributos técnicos eficazes para dar conta de rodar em terrenos fora do asfalto, são utilizados, salvo raras exceções, somente nas cidades e em ruas asfaltadas.

Os modelos de Veículo Utilitário Esportivo - VUE, ofertados no Brasil, entre nacionais e importados, apresentam-se numa gama muito grande. Existem, de um lado, os que realmente enfrentam todos os terrenos, e, do outro, aqueles que ostentam somente forma de VUE, sem entretanto apresentarem as características técnicas para tal.

Entre ser e parecer um verdadeiro VUE, muitos modelos de várias faixas de preço competem num mercado que procura aventura sem se aventurar. Para entender o sistema de discurso deste tipo de automóvel será feita uma classificação dos principais modelos disponíveis no mercado brasileiro, tendo-se como base o quadrado semiótico.

O quadrado semiótico trabalhado tem em seu eixo semântico exatamente a oposição entre o ser e o parecer. Desenvolvendo a construção deste quadrado com suas relações de contrariedade, contradição e complementaridade chega-se aos metatermos contraditórios, verdade e falsidade, e aos metatermos contrários, segredo e mentira.

Utilizando-se desta ferramenta, é possível classificar os modelos de VUE dentro destas categorias de verdadeiro, falso, segredo e mentira e contrapô-las com a publicidade trabalhada pelas marcas. 
Quadrado semiótico do ser e parecer:

\section{VERDADE}

SER

-PARECER

SEGREDO

FALSIDADE

NÃO PARECER--------------NÃO SER

\section{MENTIRA}

O metatermo "verdade" define quando o veículo possui as funcionalidades de poder trafegar em terrenos não pavimentados com desenvoltura, segurança e conforto para os passageiros, com um design apropriado e elevado do solo acima dos carros de passeio, pois ele é um VUE e se parece como tal.

A "falsidade", por sua vez, indica um veículo que apresenta o design de um VUE, porém sem as funcionalidades para a utilização fora de estrada.

Já a "mentira" indica um veículo que não parece e nem tem as funcionalidades de um VUE, ou seja, os carros de passeio de outros sub-segmentos que, portanto, então fora do escopo desta pesquisa.

Por fim, o "segredo" fala de um veículo que possui as funcionalidades necessárias para atuar fora de estrada com conforto e segurança, sem possuir, porém, o design característico dos VUE. Existem alguns carros classificados como crossover, muito pouco comercializados no Brasil, como o Subaru Outback, cujo seu design é de uma perua, mas com tração independente nas quatro rodas e boa desenvoltura fora de estrada. 
Abaixo se apresenta o quadrado semiótico com a inserção dos mais significativos representantes dos metatermos.

Quadro XIV

Quadrado semiótico para os Veículos Utilitários Esportivos.

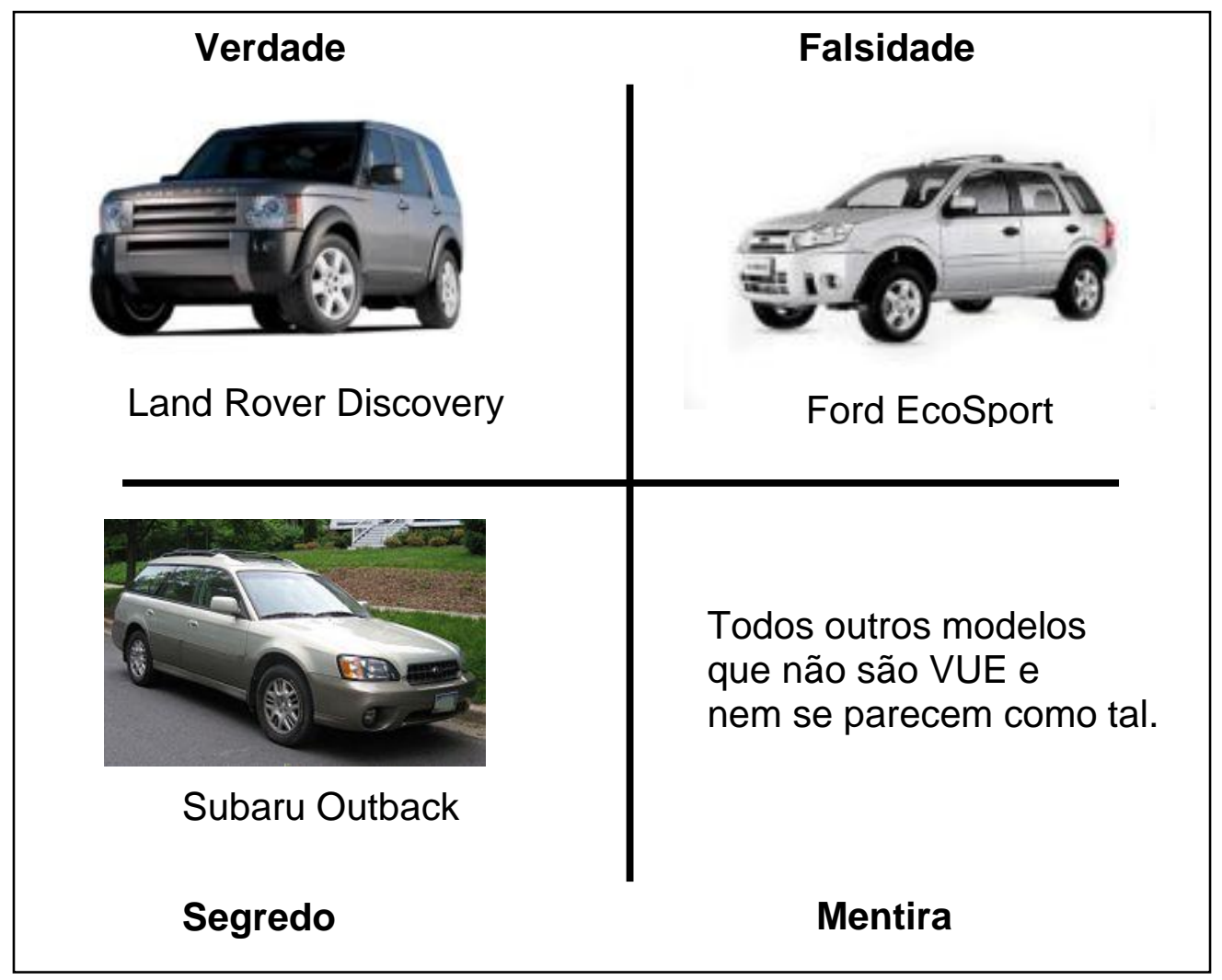

Abaixo se apresenta a classificação dentro do quadrado semiótico do SER e PARECER cruzado com o sistema de valorização do consumo de Floch dos mais significativos modelos de VUE: 
Tabela V

Tabela de classificação semiótica

\begin{tabular}{|c|c|c|c|c|c|c|c|}
\hline VEÍCULO & VERDADE & FALSO & SEGREDO & PRÁTICO & UTÓPICO & LÚDICO & CRÍTICO \\
\hline BMW série X5 & $\mathrm{V}$ & & & & & $\mathrm{L}$ & \\
\hline $\mathrm{BMW}$ série $\mathrm{X} 3$ & V & & & & & $\mathrm{L}$ & \\
\hline Chrysler Grand Cherokee & $\mathrm{V}$ & & & & & $\mathrm{L}$ & \\
\hline GM Hummer H2 & $\mathrm{V}$ & & & & & $\mathrm{L}$ & \\
\hline GM Hummer H3 & V & & & & & $\mathrm{L}$ & \\
\hline Hyundai Veracruz & V & & & & & L & \\
\hline Infinity FX 35 & V & & & & & $\mathrm{L}$ & \\
\hline Land Rover Discovery & V & & & & & L & \\
\hline Land Rover Range Rover & $\mathrm{V}$ & & & & & $\mathrm{L}$ & \\
\hline Mercedes Benz M & V & & & & & $\mathrm{L}$ & \\
\hline Mercedes Benz G & V & & & & & L & \\
\hline Mitsubishi Outlander & $\mathrm{V}$ & & & & & $\mathrm{L}$ & \\
\hline Mitsubishi Pajero Full & V & & & & & L & \\
\hline Nissan Pathfinder & $\mathrm{V}$ & & & & & $\mathrm{L}$ & \\
\hline Porsche Cayenne & $\mathrm{V}$ & & & & & $\mathrm{L}$ & \\
\hline Toyota Hilux SW4 & V & & & & & $\mathrm{L}$ & \\
\hline Toyota Land Cruiser & $\mathrm{V}$ & & & & & $\mathrm{L}$ & \\
\hline Toyota Lexus & V & & & & & $\mathrm{L}$ & \\
\hline Volkswagen Touareg & $\mathrm{V}$ & & & & & $\mathrm{L}$ & \\
\hline Volvo XC90 & $\mathrm{V}$ & & & & & $\mathrm{L}$ & \\
\hline Volvo XC70 & $\mathrm{V}$ & & & & & $\mathrm{L}$ & \\
\hline Cherokee Sport & $\mathrm{V}$ & & & & & $\mathrm{L}$ & \\
\hline GM Blazer & V & & & $P$ & & & \\
\hline Honda CR-V & $\mathrm{V}$ & & & & & $\mathrm{L}$ & \\
\hline Hyundai Santa Fé & $\mathrm{V}$ & & & & & $\mathrm{L}$ & \\
\hline Kia Sorento & $\mathrm{V}$ & & & & & $\mathrm{L}$ & \\
\hline Land Rover Freelander & $\mathrm{V}$ & & & & & $L$ & \\
\hline Mitsubishi Airtrek & V & & & & & L & \\
\hline Pajero Sport & $\mathrm{V}$ & & & & & $\mathrm{L}$ & \\
\hline Nissan X-Terra & $\mathrm{V}$ & & & & & $\mathrm{L}$ & \\
\hline Nissan XTRAIL & $\mathrm{V}$ & & & & & $\mathrm{L}$ & \\
\hline Subaru Forester & $\mathrm{V}$ & & & & & $\mathrm{L}$ & \\
\hline Subaru Outback & & & $S$ & & $U$ & & \\
\hline Palio Adventure & & $\mathrm{F}$ & & & $U$ & & \\
\hline Ford EcoSport & & $\mathrm{F}$ & & & $U$ & & \\
\hline GM Tracker & $\mathrm{V}$ & & & & $\mathrm{U}$ & & \\
\hline Hyundai Tucson & $\mathrm{V}$ & & & & $\mathrm{U}$ & & \\
\hline Kia Sportage & $\mathrm{V}$ & & & & $\mathrm{U}$ & & \\
\hline Mitsubishi Pajero TR4 & $\mathrm{V}$ & & & & $U$ & & \\
\hline VW Crossfox & & $\mathrm{F}$ & & & $U$ & & \\
\hline
\end{tabular}


Analisando-se a tabela acima e comparando-a com os preços de cada modelo, fica claro que os verdadeiros VUE são os que apresentam preços mais elevados, pois para ser e parecer um utilitário esportivo que reúna toda a tecnológica necessária o custo de produção sobe bastante. Por conta disso, estes modelos representam poder e status; seus compradores usufruem de marcas de luxo, como BMW, Mercedes-Benz e Porsche, que podem ser classificadas no sistema de valorização do consumo de VUE como lúdicas. O discurso publicitário para os VUE's lúdicos exploram a exclusividade.

Uma segunda classificação para os verdadeiros é a lúdica. Nesta se encontram os veículos cujas marcas não expressam exclusividade nem luxo, pois produzem carros de todos os níveis. Neste caso, os consumidores valorizam seus estilos de vida, aspiram a viver um ideal, uma aventura, mas sem riscos.

Dentre os verdadeiros, há uma exceção que não é lúdica e nem utópica, e sim prática. Trata-se da GM Chevrolet Blazer, que, por estar com suas linhas ultrapassadas, não inspira o luxo nem o glamour do lado emocional. Este veículo é consumido para fins práticos, sendo mais utilizado na frota pública, como a da Policia Militar.

Os veículos classificados como falsos (pois não são preparados para atuar fora de estrada), mas que aparentam ser, são também classificados como utópicos, pois seus consumidores, mesmo sabendo de suas limitações, valorizam muito o seu design robusto. Tais consumidores procuram, por meio destes veículos, uma pseudo-aventura.

Resumindo, o discurso publicitário divide-se basicamente entre verdadeiros e falsos VUE. Para os verdadeiros, o discurso mostra as funcionalidades como suporte à sedução pelo luxo e exclusividade. Para os falsos, o discurso publicitário trata somente dos aspectos emocionais, como design, aventura e estilo de vida. 


\section{A DINÂMICA DO POSICIONAMENTO DE MARCA}

Neste capítulo será abordada a questão da fluidez dos significados na sociedade de consumo contemporânea e sua influência no posicionamento de marcas, o que exige das empresas uma constante atualização da comunicação para fazer frente à demanda de sentido do público consumidor.

Para tanto, será proposto aqui um posicionamento dinâmico de marca. Ao contrário das práticas de mercado, que propõem uma manutenção da posição da marca por um tempo considerado, este processo propõe uma convivência constante com a tensão entre manter-se numa determinada posição ou fluir conforme a dinâmica do mercado. 


\subsection{A dinâmica do mercado}

Como visto no capítulo relativo à cultura do consumo, os valores da sociedade contemporânea apresentam-se cada vez mais voláteis. Os significados fluem de forma tão rápida que não há tempo suficiente para se solidificarem na cultura (BAUMAN, 2007). Este movimento se reflete diretamente na valorização da marcas, constituindo-se num grande desafio para a construção da identidade marcaria e, conseqüentemente, sua imagem perante seus consumidores.

Parte importante do capital da marca vem das associações que as ferramentas de comunicação procuram construir na mente do público receptor (AAKER, 1998), tendo como base o posicionamento gerado nas estratégias de marketing. Nesse sentido, é fundamental entender a dinâmica do mercado, a fim que a comunicação esteja sempre em sintonia com o momento.

Para entender o fluxo dos significados, suas movimentações e como eles influenciam a imagem da marca, é necessário recorrer ao esquema teórico proposto pelo antropólogo canadense, Grant McCracken, relativo ao fluxo de significados na cultura de consumo e sua recente atualização, que ele chama de "agrupar e fluir" (McCRAKEN, 2006).

Segundo ele, o significado se movimenta do mundo culturalmente constituído para os bens de consumo, e destes para os consumidores individuais. No primeiro estágio, da cultura para as marcas e mercadorias, os principais impulsionadores são a publicidade e o sistema da moda. No segundo, da marca para o indivíduo, são quatro rituais que transferem o significado: o ritual da posse, da troca, da arrumação e do despojamento. (McCRAKEN, 2003: 100)

O mundo culturalmente constituído é a localização original do significado, é nele que ocorrem os fenômenos captados pelos sentidos do indivíduo e moldados segundo a sua cultura. Assim, o indivíduo enxerga o mundo através de seus óculos culturais, pelos dos quais ele é orientado segundo um plano de ação, caracterizado por categorias e princípios culturais, e que estabelece os usos, costumes, valores e princípios que moldam o comportamento humano.

As categorias culturais organizam tempo, espaço, classes sociais, gênero, idade e ocupação. Sua materialização se faz por meio das práticas humanas e pelos objetos materiais, mercadorias e marcas. A utilização das marcas organiza as 
distinções das categorias, ajudando o consumidor a estruturar sua própria identidade. Ou seja, através das marcas de roupas, carros, etc., o consumidor caracteriza sua idade, sexo, ocupação, bem como suas aspirações.

O consumidor, por fim, escolhe o significado que vai extrair das marcas, e, por conta disso, ele é um agente ativo no processo de significação. As marcas carregadas de significados culturais vão contribuir para a construção da identidade do consumidor e organizar suas aspirações.

A comunicação é uma impulsionadora de significado, vestindo as marcas com os significados mais nobres e valorizados, procurando colocar a marca anunciada em conjunção com os valores da cultura e as aspirações do consumidor. Nesse momento, retoma-se a importância do posicionamento, pois é este processo que vai trabalhar a conjunção da marca com seu público.

Vale ressaltar que os significados gerados no mundo cultural ganharam nova dinâmica de valores e sentido com o desenvolvimento dos meios eletrônicos, da internet e das comunidades virtuais. Agora, os produtores de significados não estão mais polarizados nos mecanismos da indústria cultural. Sítios como o You Tube (WWW.youtube.com) trazem para milhões de internautas conteúdos culturais gerados em casa, os quais, em várias oportunidades, sobem para a mídia de massa convencional, orientando novas tendências.

Talvez a definição mais apropriada para a fonte de significado e valores da atual sociedade seja a metáfora de um vulcão em atividade, dentro do qual tudo está revolto, misturado e em estado liquido, até o ponto de transbordar, escorrer pelas encostas, destruir aquilo que está pelo caminho para se solidificar e se transformar em rocha já sem sentido algum.

$\mathrm{Na}$ visão de McCracken os valores e significados surgem num caos e caminham num continuum para uma rigidez que determina um hábito ou um costume já pronto pra ser ultrapassado. Segundo o antropólogo, é neste continuum, fluido e inconstante, que mora a inovação, a qual por algum tempo vai determinar os significados valorizados pelo público. O autor baseou-se na teoria da complexidade, que diz que a "ordem vem do dinamismo em que as coisas mudam", e do continuum de Stuart Kauffman, que demonstra que um "sistema de valores floresce no limite do caos", (McCRACKEN, 2006: 4) 
Nesta visão, e também na de Bauman e Lipovetsky, os consumidores mudam suas preferências e suas mentes de forma imprevisível, inconstante e a todo tempo. A indústria cultural não tem mais o domínio do ciclo daquilo que vai fazer sucesso e entrar na moda. Cabem às marcas o papel de criar também conteúdos, para que seus consumidores possam re-significar suas identidades constantemente.

A marca, como provedora de significados para o público, exige que seu administrador seja um gerente de significado. Para tanto, este deve analisar sempre a tensão entre manter um posicionamento ou mudá-lo para fazer frente às novas significações. 


\subsection{A dinâmica da marca}

Como visto no capítulo referente às marcas, estas se transformaram num dos ativos mais importantes de uma empresa. Mas o ponto que motivou esta pesquisa é que toda essa importância e crescimento se evidenciaram numa época de crescimento, deslumbramento e exuberância, na qual os valores eram ditados pela indústria cultural, transferiam-se para as marcas e destas para o consumidor, num caminho sedimentado e previsível.

No final do século $\mathrm{XIX}$ e em quase totalidade do século $\mathrm{XX}$ as marcas que souberam trabalhar de acordo com uma proposta de missão bem definida, clara e consistente, tanto nos seus produtos como nos seus discursos, usufruíram de um grande terreno para crescer e prosperar.

Hoje não existe mais este espaço, e novas marcas brigam com outras tradicionais por pequenos nichos. Vão ser bem sucedidas aquelas que se conectarem com seu público receptor, provendo-Ihes significados para uma constante construção de personalidades.

A comunicação da marca deve estar sempre propondo novas posturas, inovações e conteúdos alinhados com as características de sua mercadoria, com as dinâmicas do mercado e com as dinâmicas do público receptor. Portanto, a marca está inscrita em um processo de produção de discurso constante.

Cada atitude da marca, seja na comunicação, seja para com seus funcionários, seja na qualidade de suas mercadorias, é um ato discursivo, um enunciado. "Cada ato da marca implica em uma nova enunciação que se junta em continuidade às enunciações anteriores... esta atividade de reafirmação enunciativa é uma atividade contínua e incrivelmente prolífica". (SEMPRINI, 2005: 118)

$\mathrm{Na}$ visão deste trabalho, o processo de enunciação de uma marca se inicia com o processo de seu posicionamento na mente do público. Assim, fica claro que o posicionamento da marca é um processo que deve levar em conta todo o aspecto dinâmico dos valores e significados do consumo. 


\subsection{A dinâmica do público receptor}

Os indivíduos, nos grandes centros urbanos, estão se inserindo numa era imagética, na qual a realidade se deslocou do mundo exterior, concreto, organizado pela experiência, para um mundo fora desta última, organizado pelas imagens nas telas da televisão, do cinema e, principalmente, do computador. Essa nova realidade está redefinindo o comportamento humano. (DAVIS, 2003)

As motivações do indivíduo têm sua origem no instinto de sobrevivência, no bem-estar e na vontade de procriar. Os desejos e necessidades humanas achavamse então ligados às experiências num mundo físico. Na sociedade contemporânea, porém, tal constatação não é mais verdadeira. Há uma nova realidade, a realidade virtual, que põe em risco o bem-estar do indivíduo, ameaçado pelos entes imateriais como o estresse, a angústia e o medo de ficar ultrapassado.

A grande profusão de imagens como mediadora da realidade envolve-o num mundo multifacetado, distante da realidade física, obrigando-o a se conformar e sobreviver nessa situação, preservando sua saúde mental e buscando o prazer da felicidade interior.

Várias empresas, atentas a esta nova realidade, já promovem suas marcas no sentido de pôr à disposição de seus consumidores discursos que procuram satisfazer esses desejos. Cada vez mais se observa um distanciamento do mundo real da fabricação das mercadorias do mundo ideal dos discursos que encarnam promessas divinas para seus produtos mundanos.

As marcas estão se transformando em avatares, utilizadas que são para representar uma identidade a que se aspira e que vai trazer uma esperança de felicidade para o indivíduo consumidor. Os principais valores orbitam entre a inovação, para não se sentir ultrapassado perante uma obsolescência estrutural constante; a paz interior, como antídoto contra o estresse e a angústia do sofrimento coletivo diante das tragédias da TV; a boa forma física, para fazer frente à modelagem estética nas telas; o poder, para vencer nesta selva urbana e, por fim, a segurança. Estes valores multiplicam-se em vários outros, que se revestem de várias formas, num jogo dinâmico que exige das marcas uma postura atual e flexível. 


\subsection{Conceito do posicionamento dinâmico de marca}

Tendo em vista este estado líquido da sociedade de consumo (BAUMAN,2007), a proposta deste trabalho é apresentar um posicionamento líquido também, que possa fluir na comunicação, conformando-se assim às mudanças de valores, de costumes e práticas. Tal posicionamento deve catalisar toda a comunicação com o público, de forma a apresentar, independentemente dos meios, uma mesma mensagem integrada e consistente.

Os princípios de um posicionamento dinâmico de marca são três: identificação com a missão da marca e a estratégia da empresa, conexão com o público receptor e integração da mensagem em todas as ferramentas de comunicação. Ressalte-se ainda que o posicionamento de marca é um processo que conecta a marca ao público por meio da comunicação, oferecendo um benefício, ora funcional ora emocional, que diferencie e destaque a marca frente aos concorrentes, chamando a atenção deste público e levando-o a desejar e considerar a compra das mercadorias ofertadas com a marca.

O ponto central do processo de posicionamento é a escolha do conceito fundamental sobre o qual se vai construir o enunciado do posicionamento. Este deve ser diferenciador, pertinente às características funcionais da mercadoria, alinhado com a história da empresa e da marca, integrador, presente em todas as expressões da marca e valorizado pelo público receptor. Para tanto, este conceito deve sintetizar o caráter, ou história da marca, e se personificar de uma forma tal que reflita na mente do público a essência de sua identidade e de seus desejos.

A construção dessa personalidade de marca é parte do processo de posicionamento, e se dá quando se constrói o enunciado, subindo pelas estruturas narrativas e discursivas. É nesta fase que o gerente de marca deve estar conectado aos movimentos de significados e constantemente atualizar o enunciado do posicionamento para fazer frente às dinâmicas da sociedade de consumo. Esta atualização ocorre nas estruturas narrativas e discursivas. 
Na figura abaixo se encontra as fase do processo de posicionamento passível da atualização fruto do gerenciamento de significado:

Quadro XVI Processo de posicionamento semiótico dinâmico da marca

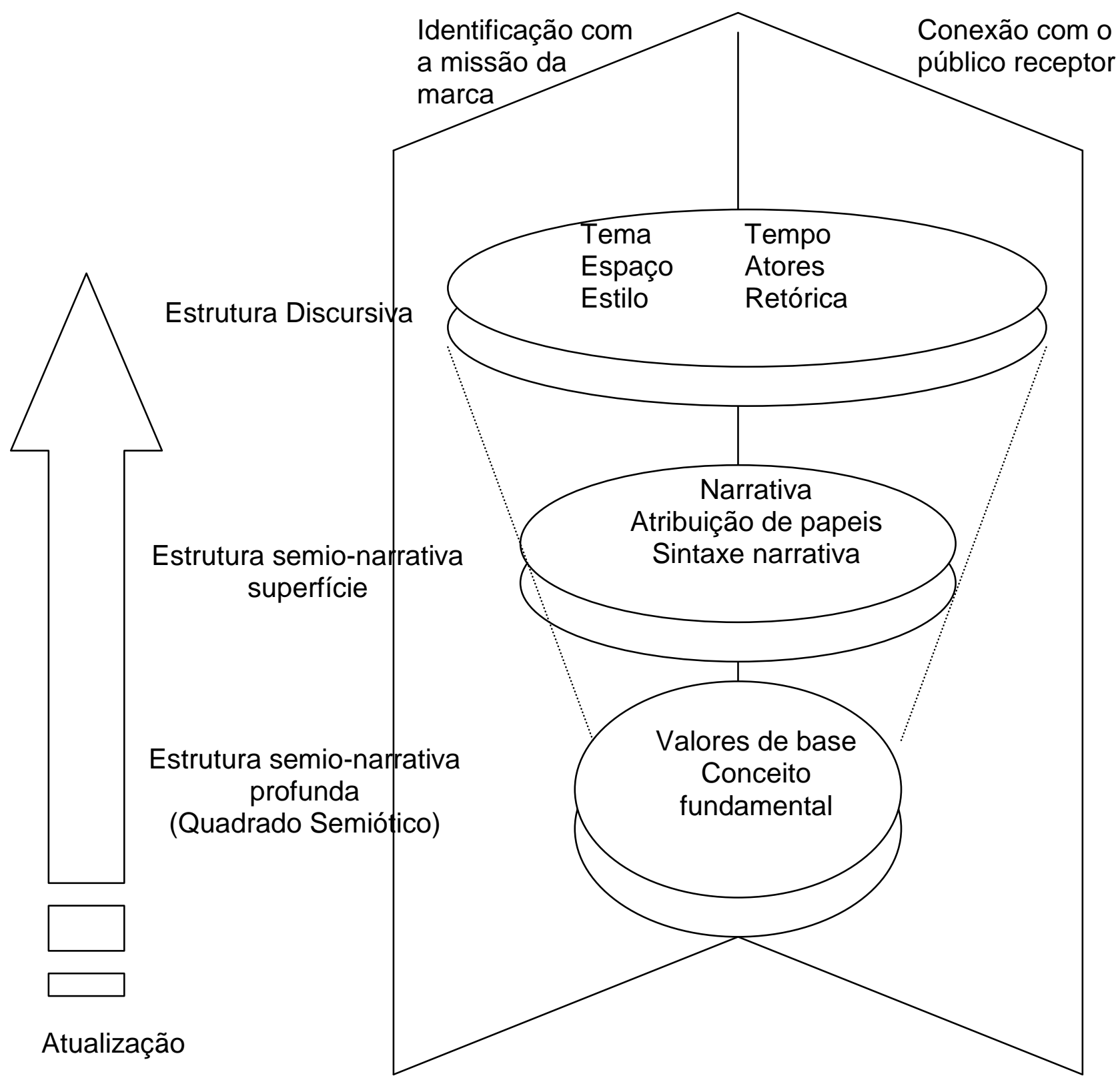


A atualização deve ocorrer partindo da estrutura mais profunda até o enunciado, sempre pautada pela missão da marca e pelos valores do público receptor. $O$ fator determinante, a escolha do conceito fundamental, se dá no quadrado semiótico dos valores do consumo e, portanto, já se inicia conectado ao público.

Quadro XVII

Quadrado semiótico do consumo (FLOCH, 1993)

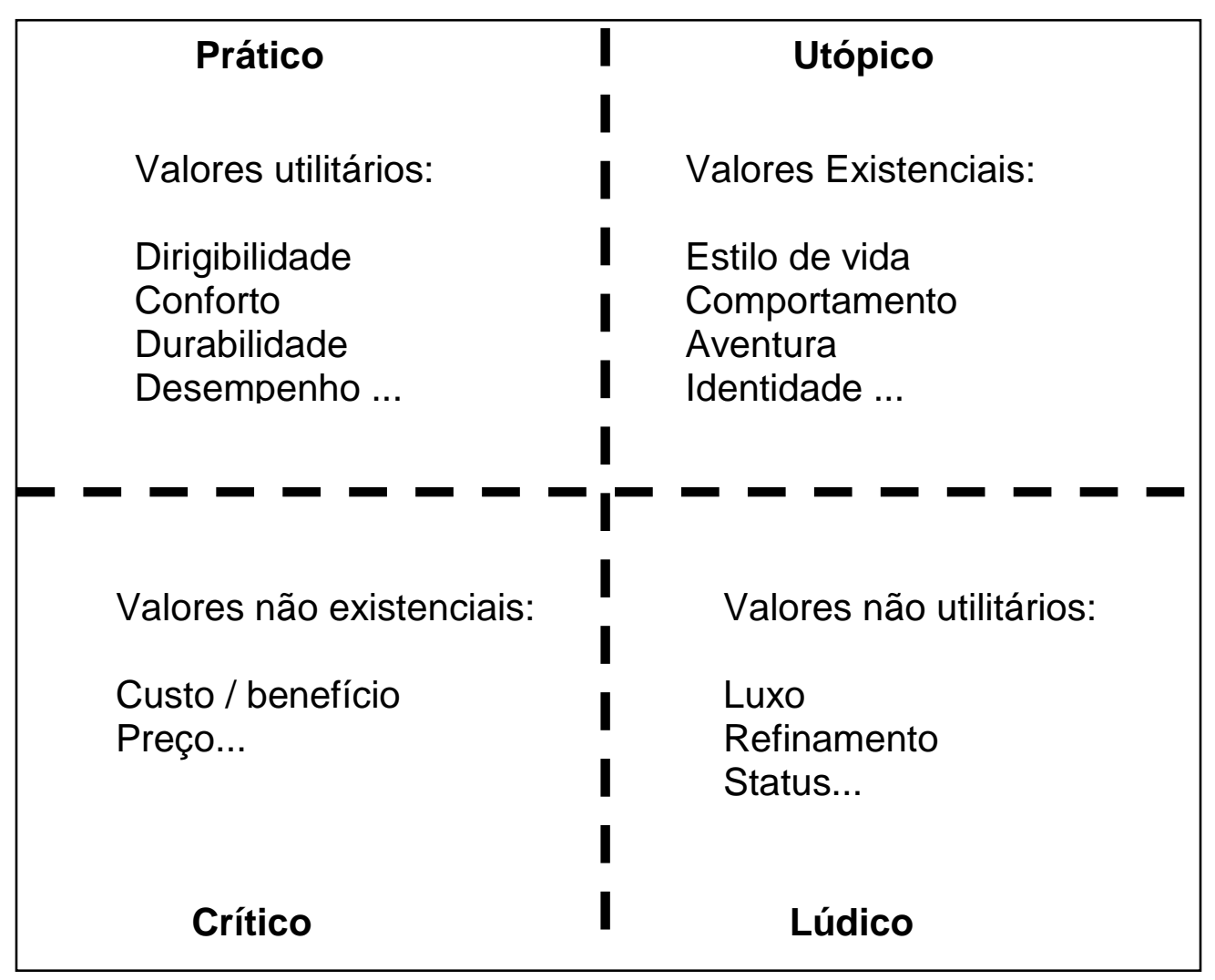

Conforme os valores e significados vão fluindo na sociedade eles percorrem os quatro quadrantes de valores identificados por Floch. A escolha por um conceito dentro de um dos quadrantes é baseada na análise prévia de onde se coloca a concorrência e naquilo que melhor se conecta ao público e que está alinhado com a missão da empresa e as características da mercadoria. 
Como exemplo, segue uma construção meramente ilustrativa de como escolher o conceito fundamental do posicionamento da marca.

Os relógios de luxo das marcas Rolex, Breitling e Tag Heuer apresentam semelhantes preços e posicionamentos no quadrante Lúdico, porém é evidente a diferenciação entre eles, sendo o Rolex mais clássico e tradicional, o Breitling mais sofisticado e o Tag Heuer luxuoso mais com um acento bem esportivo, que invade um pouco o território Utópico.

Analisando esse mercado, caso uma nova marca de relógio de luxo queira se posicionar ela deverá procura uma diferenciação em relação a estas três marcas líderes, por exemplo: luxo sem ostentação, com design mais limpo, sugerindo algo mais discreto, que também invade o quadrante Utópico.

Quadro XVIII

Quadrado semiótico para seleção do conceito fundamental

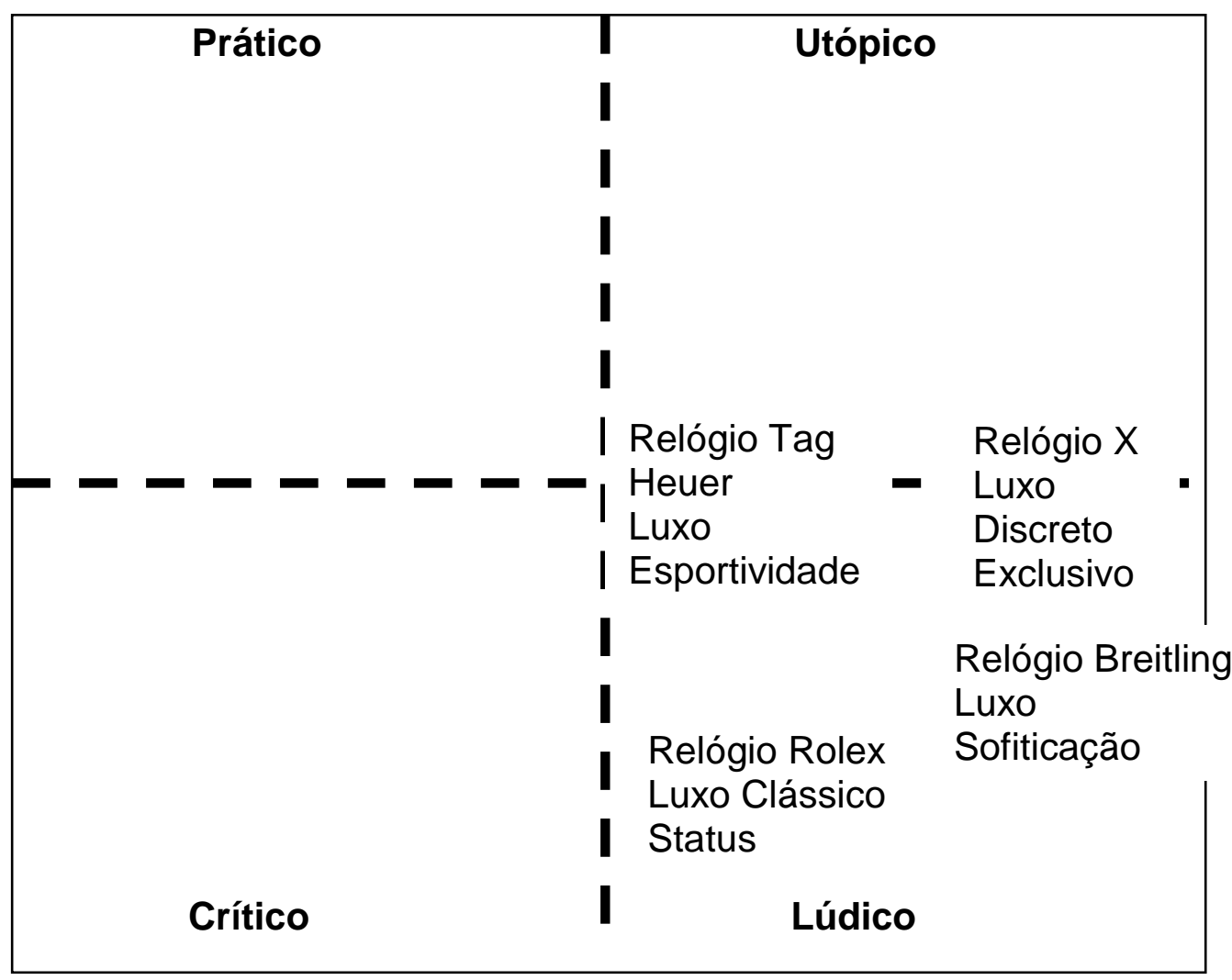


Seguindo os passos do processo de posicionamento semiótico do primeiro capítulo, chega-se ao enunciado do posicionamento, ao briefing, e finalmente a agência de publicidade constrói toda a comunicação e finaliza com um slogan, que é o produto final do processo de posicionamento de marca.

Esse processo necessita ser atualizado no momento em que forem detectadas no mundo cultural mudanças que vão interferir no conjunto de valores e significados que a marca representa. Cabe ao gestor identificar o potencial de mudanças, avaliar a necessidade de atualização da posição e reposicionar.

Qualquer tentativa de modelar esse reposicionamento pode levar a uma burocracia metodológica sem resultados. Essa tarefa exige uma bagagem cultural considerável e certa compreensão dos fenômenos sociais. Pesquisas de tendências, técnicas etnográficas e um olhar semiótico para a cultura de consumo são ferramentas indispensáveis para o gestor do significado da marca.

Para verificar a necessidade de atualização constante do posicionamento da marca na mente do público, tornando este processo algo constante e não mais esporádico, será estudado o automóvel Ford EcoSport, através da sua comunicação desde o seu lançamento até outubro de 2008. Este estudo será construído com base na semiótica greimasiana aplicada às publicidades realizadas pela montadora em mídia impressa. 


\section{ANÁLISE DA DINÂMICA DO POSICIONAMENTO DO ECOSPORT}

Este capítulo tem como objetivo verificar a necessidade de o gestor da marca atualizar o posicionamento para a comunicação, numa periodicidade mais freqüente do que a prática desta atividade apregoa, devido à dinâmica da sociedade contemporânea de consumo.

A hipótese da presente pesquisa é de que a dinâmica dos valores e significados que circulam na sociedade de consumo atual esta extremamente fluida, não permitindo solidificações. A inovação constante e o medo do obsoletismo estrutural fazem com que o público viva constantemente procurando por novidades que the tragam alivio e, por certo tempo, a sensação de estar vivo.

Apesar de o automóvel ser um bem de consumo durável, é também propósito deste trabalho demonstrar que os valores de base, de fundo emocional, se agregam e desagregam às mercadorias, como se fossem fantasias que caracterizam uma personagem que determinado público quer utilizar para construir a identidade a aspirada.

Nesse sentido, embora o ciclo de vida do automóvel tenha uma vida média acima de cinco anos. Neste período, para se manter atual no mercado ele deve investir e se revestir de uma comunicação dinâmica e conectada com seu público, ao contrário da prática de posicionamento, o qual, por ser considerado estratégico, presume-se que deva permanecer por um tempo considerável a fim de se sedimentar na mente do consumidor. Esta tensão entre manter uma posição e atualizá-la na comunicação é o foco desta verificação.

Durante o período de estudo desta pesquisa serão analisadas três fase da comunicação desse modelo: lançamento, maturação, atual. 


\subsection{Lançamento do EcoSport}

O lançamento do EcoSport ocorreu em março de 2003. O veículo foi o segundo modelo produzido na fábrica da Ford de Camaçari, no estado da Bahia. O primeiro, o Novo Ford Fiesta, cede a sua plataforma para este carro, que tem como proposta ser um utilitário esportivo compacto. Seu primeiro slogan, marcando seu posicionamento era "Bem vindo à vida".

Figura I
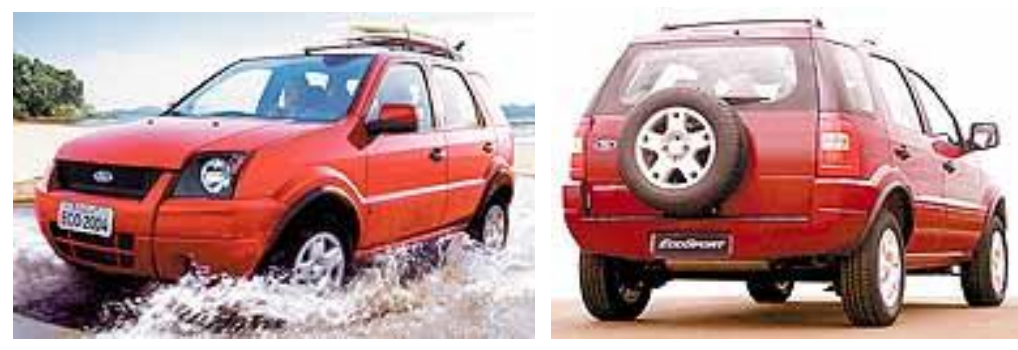

Fotos divulgadas pelo departamento de imprensa da Ford

Figura II

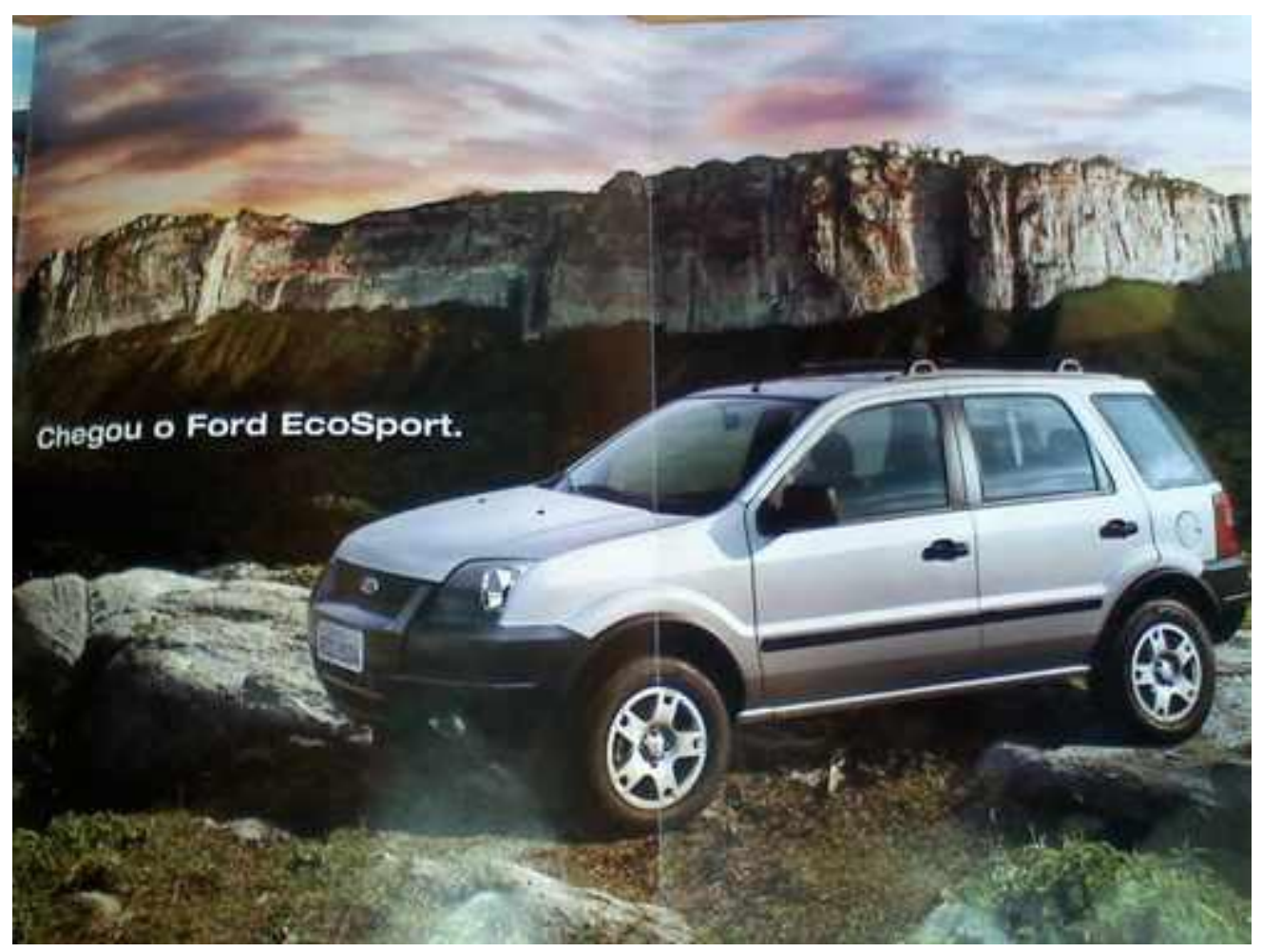

Catálogo de lançamento 
Figura III

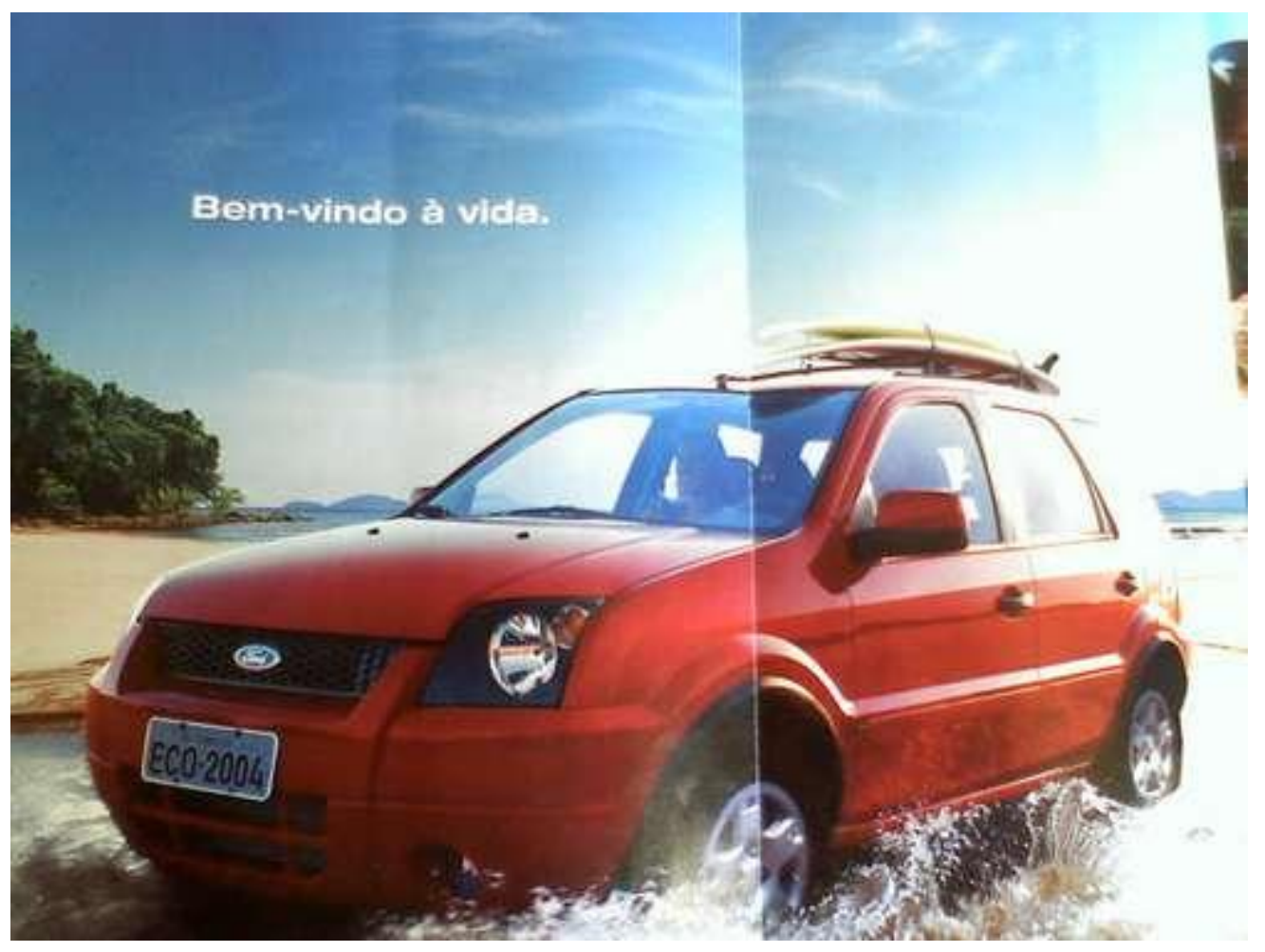

Catalogo de lançamento

O lançamento foi cercado de grande expectativa, no principio chamado como projeto Amazon, o Ford EcoSport chegou como uma grande novidade que gerou várias notícias, dentre tantas foi selecionado o texto da jornalista Elen Cristina, (http://www.gustacar.hpg.com.br/lancamentos.EcoSport.htm)

"Veículo de desenho jovem e moderno, ele se destaca pelas linhas fortes e funcionais. O estepe fixado do lado de fora da tampa traseira e o porte elevado deixam clara a sua disposição fora-de-estrada. Os pára-choques, de desenho robusto, são pintados com tinta especial ou na cor da carroceria, dependendo da versão. Na dianteira, além da entrada de ar em forma de trapézio, ele traz embutidos os faróis de neblina (opcionais) e gancho para reboque. Os faróis, com lentes de linhas retas e refletor interno redondo, incorporam também as luzes dos piscas.

O pára-choque traseiro, estruturado para suportar o peso de uma pessoa em pé e revestido com material antiderrapante, serve de degrau para facilitar 0 acesso à bagagem. $A$ 
ampla porta traseira, de abertura horizontal, a partir do lado direito, traz embutida a luz elevada de freio. Detalhes em preto, presentes no contorno dos pára-lamas e das janelas e nas colunas traseiras, produzem um bonito efeito visual. $O$ bagageiro opcional no teto, regulável, permite acomodar diferentes tipos de carga. O estepe tem remoção fácil e é protegido por sistema de porca antifurto. Externamente, as molduras laterais são pretas ou pintadas na cor do veículo.

Graças ao processo de última geração de tratamento da carroceria, por eletrodeposição de material catódico, que garante a qualidade e alta resistência dos materiais contra riscos, o EcoSport tem cinco anos de garantia contra corrosão. A garantia total, de pára-choque a pára-choque é de um ano, incluindo bateria e pneus.

Internamente, o EcoSport tem capacidade para cinco passageiros, o porta-malas tem capacidade de 292 litros e pode chagar a 712 litros com o banco rebatido. Para sonorizar o ambiente, são oferecidos como opcionais CD players e MP3 players com viva-voz para celular, CD changer para seis discos, alto-falantes de alta potência, subwoofer e amplificadores.

No quesito conforto, os principais equipamentos do EcoSport são os vidros, travas e retrovisores elétricos, tapetes de borracha e carpete, kit de película de proteção solar e rede porta-objetos. Os três primeiros são opcionais na versão básica, a exemplo do compartimento refrigerado no porta-luvas vinculado ao ar condicionado, mas que tem que ser preterido se o comprador optar pela versão XLT 2.0, a mais sofisticada. É porque a XLT vem com airbag duplo de série, sendo que a bolsa inflável para o passageiro ocupa o lugar da minigeladeira. Outra grande atração do EcoSport é o porta-objeto sob o assento do passageiro, de série em todas as versões.

A segurança também tem seu valor no EcoSport: alarme, protetor de cárter, faróis de neblina, borracha protetora do pára-choque, defletor de capô, jogo de calhas, borracha de proteção do porta-malas. A versão $2.0 \mathrm{XLT}$ oferece de série os freios $\mathrm{ABS}$.

O EcoSport possui três tipos de motorização. A básica é o Zetec Rocam $1.0 \mathrm{~L}$ Supercharger, 8 válvulas com compressor volumétrico e 95 cavalos. Com ele, veículo acelera de 0 a $100 \mathrm{~km} / \mathrm{h}$ em 14,8 segundos e atinge a velocidade máxima $157 \mathrm{~km} / \mathrm{h}$. É o mesmo motor que estreou no Fiesta. Também do modelo hatch vem o Zetec Rocam $1.6 \mathrm{~L} 8$ válvulas e três cavalos a mais. Acelera em 13,4 segundos e faz a velocidade máxima de $160 \mathrm{~km} / \mathrm{h}$.

Também são três as versões de acabamento do EcoSport. A mais simples é a XL, diferenciada pelos pára-choques pretos e que tem a opção dos motores 1.0 e 1.6. Seus principais equipamentos de série são a direção hidráulica, coluna de direção e banco do motorista com regulagem de altura, ganchos para reboque dianteiro e traseiro, imobilizador, aquecedor, aviso sonoro do farol aceso, retrovisores com comando manual e bancos traseiros bipartidos. 
A intermediária XLS pode ser comprada apenas com o motor 1.6 e adiciona de série o ar-condicionado e a minigeladeira, o trio elétrico, os auto-falantes (opcionais no XL que só vem com a antena e a fiação) e o bagageiro no teto. $O$ airbag para o motorista, o cinzeiro e o acendedor de cigarros são opcionais nas duas versões. A mais completa, a XLT, com párachoques na cor do veículo, oferece ar condicionado (mas sem a minigeladeira), o airbag duplo, as rodas de liga-leve e a tomada de força no porta-malas. Os bancos de couro são opcionais.

O Ford EcoSport tem como principais atributos: design moderno e robusto, altura livre do solo, posição alta de dirigir, visibilidade, boa dirigibilidade no asfalto e na terra, espaço interno amplo e flexível e preço acessível a partir de $R \$ 31.190$ na versão XL 1.0. Mesmo com visual de todo-o-terreno, o EcoSport ainda não tem tração $4 \times 4$ que só chega no segundo semestre."

Embora o design e a propaganda sugerissem claramente um carro para se utilizar fora de estrada, ou seja, com a funcionalidade da tração nas quatro rodas, somente três meses após o lançamento a Ford apresenta uma versão do modelo com essa funcionalidade, era o EcoSport com motor 2.0 16V, denominada 4WD, (four wheel drive) cuja ativação da função $4 \times 4$ se dava através de um botão no painel de instrumentos.

Essa nova versão respondia as críticas da imprensa automotiva brasileira relativa à incapacidade do modelo de enfrentar os obstáculos de rodar fora de estrada, porém como esta versão tinha um preço muito superior às outras versões sem a tração nas quatro rodas suas vendas nunca foram expressivas, prevalecendo no mercado as versões sem esta funcionalidade.

Dois anos depois, em maio de 2005, a Ford lança o motor 1.6 Flex (motores com possibilidade de serem abastecidos com álcool combustível ou gasolina) para a linha, tirando de produção motor 1,6 litro a gasolina. Logo depois, em novembro de 2005, sai de linha a versão top 2.0 16V, embora o 4WD permaneça em produção, entra a série especial Freestyle e o kit Camaleão. Em abril de 2006 a Ford tira de linha o motor 1 -litro Supercharger muito criticado para um carro cuja proposta era a aventura.

Apesar das críticas a imprensa sempre entendeu que o EcoSport apresentou uma proposta inovadora no mercado brasileiro. Os utilitários esportivos são objetos de desejos dos consumidores de automóveis, seja masculino ou feminino, pelas 
razões já expostas nesse estudo. O site Web Motors considera o EcoSport um grande sucesso "O EcoSport foi o maior acerto da Ford no Brasil após o divórcio da Volks, na Autolatina, e proporcionou a retomada de crescimento no mercado interno. Foi lançado em 2003 e logo se transformou em objeto de desejo, especialmente do público feminino. Alto em relação ao solo, com desenho bonito e aspecto valente, o EcoSport transmite segurança e poder. $E$ atende aos desejos do consumidor de ter um carro fora-de-estrada". (http://www.webmotors.com.br)

Desde o seu lançamento até julho de 2008 o EcoSport já vendeu mais de 235 mil unidades e é o líder em sua categoria.

Tabela VI

Vendas anuais do EcoSport

\begin{tabular}{|lrrrrrr|}
\hline & 2003 & 2004 & 2005 & 2006 & 2007 & (JUL) \\
\hline ECOSPORT & 29081 & 41329 & 46084 & 44114 & 47961 & 29289 \\
\hline
\end{tabular}

Fonte: RENAVAM

Tabela VII

Segmento utilitários esportivos - sub-segmento pequenos

\begin{tabular}{|llr|}
\hline MARCA & MODELO & VENDAS 2007 \\
CHRYSLER & PT CRUISER & 2423 \\
FORD & ECOSPORT & $\mathbf{4 7 9 6 1}$ \\
GENERAL MOTORS TRACKER & 6729 \\
HYUNDAI & TUCSON & 12659 \\
KIA & SPORTAGE & 2270 \\
MITSUBISHI & PAJERO TR4 & 7692 \\
VOLKSWAGEN & CROSSFOX & 27317 \\
\hline
\end{tabular}

Fonte RENAVAM 
Comparando o EcoSport com outros modelos na mesma faixa de preço verifica-se a força de sua proposta de ser um utilitário esportivo.

Tabela VIII

\begin{tabular}{|lllrr|}
\hline SUB SEGMENTO & MARCA & MODELO & VENDAS 2007 & PREÇO (R\$) \\
UTILITÁRIO PEQUENO & FORD & FORD & 47961 & $50.000,00$ \\
MINIVAN COMPACTA & HONDA & FIT & 35395 & $50.000,00$ \\
MINIVAN COMPACTA & CHEVROLET & MERIVA & 23150 & $52.000,00$ \\
HATCH PEQUENO & VOLKSWAGEM & POLO & 22725 & $46.000,00$ \\
PERUA COMPACTA & PEUGEOT & SW & 19285 & $48.000,00$ \\
HATCH COMPACTO & VOLKSWAGEM & GOLF & 14050 & $49.000,00$ \\
HATCH COMPACTO & FIAT & STILO & 13413 & $50.000,00$ \\
\hline
\end{tabular}

Fonte: RENAVAM e revista Quatro Rodas, julho 2007

Analisando esses dados fica evidente o sucesso desse modelo, que apesar de ser um falso utilitário esportivo, conforme a classificação no quadrado semiótico da página 91, ele é sem dúvida um objeto de desejo.

Partindo então da premissa do sucesso do EcoSport será analisado a dinâmica do seu posicionamento de marca na comunicação deste modelo. 


\subsection{Análise semiótica da dinâmica do posicionamento do EcoSport}

Para dar conta desta análise, serão aplicadas a semiótica greimasiana e a teoria semiótica do texto. Serão ainda analisadas as cinco principais peças de propaganda na mídia impressa: lançamento do EcoSport, em abril de 2003, lançamento do modelo flex combustível, que permite a utilização com gasolina ou álcool combustível, e o lançamento do novo EcoSport, re-estilizado em 2008.

Todos os anúncios serão analisados com o objetivo de extrair o enunciado posicionamento da marca EcoSport no momento da veiculação, e verificar, sob uma perspectiva diacrônica, se houve alguma mudança estratégica, seja na estrutura narrativa, na estrutura discursiva ou mesmo na essência da marca.

Retomando a semiótica greimasiana, o modelo teórico de análise será o percurso gerativo de sentido, partindo do signo concreto, os anúncios, descendo nas estruturas até chegar ao nível mais profundo, abstrato e conceitual, onde está a essência do posicionamento da marca.

Ressalte-se que as cinco páginas compõem um texto, o qual, conseqüentemente, é passível de uma análise semiótica, pois possui começo, meio e fim. Seus códigos lingüísticos e visuais contam uma estória.

A par disto, será realizada uma análise geral dos códigos visuais e suas relações com os lingüísticos, bem como o estatuto pragmático do anúncio e sua relação com o contexto, seja do ambiente, do veículo que foi publicado, seja do repertório do público receptor.

Primeiro momento da análise do posicionamento: Lançamento

Abaixo está o primeiro anúncio da marca por ocasião do seu lançamento, inserido na revista semanal Veja, em abril de 2003. O anúncio é composto de cinco páginas, que formam uma narrativa, culminando com a apresentação do carro e seu preço. 


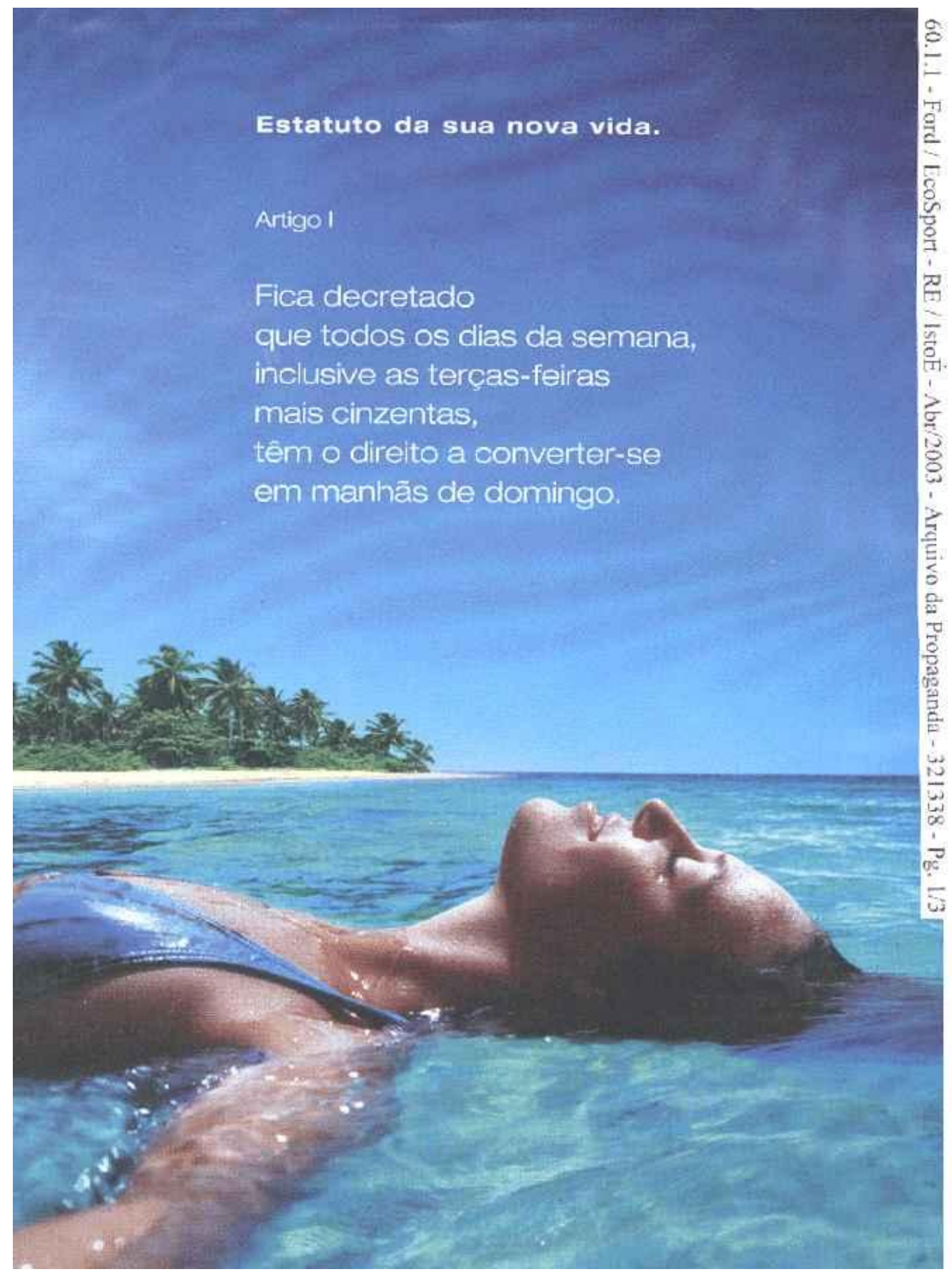




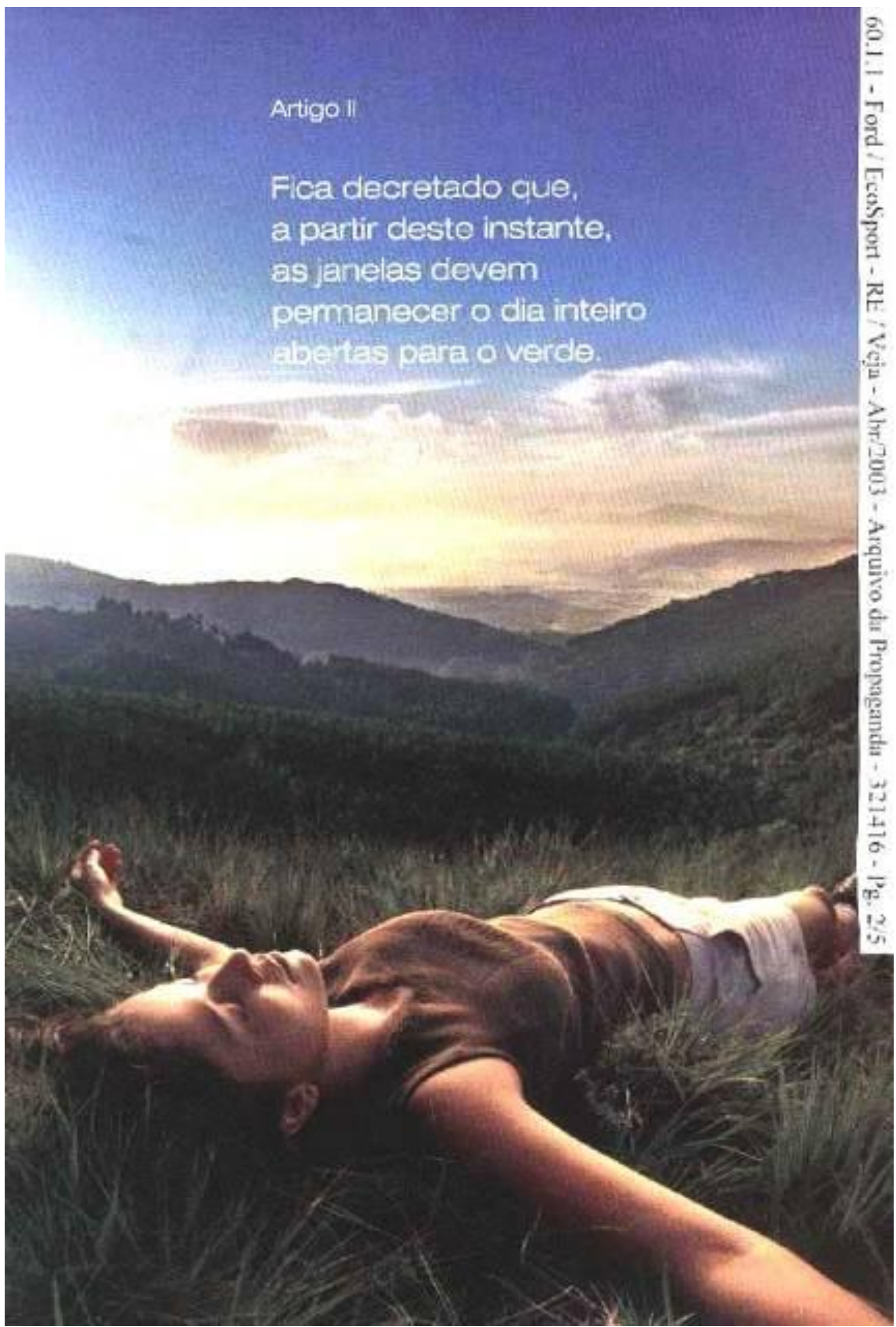




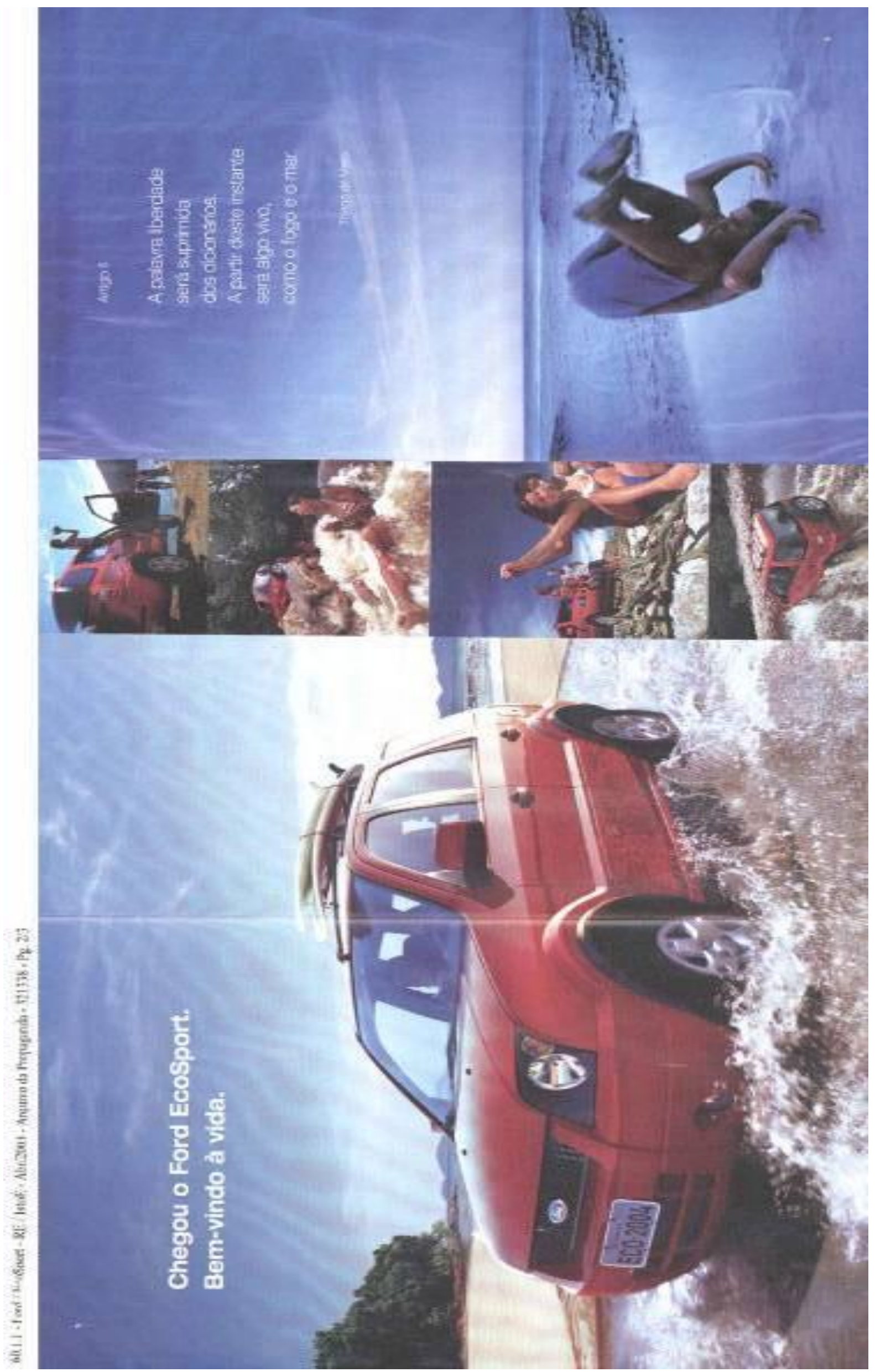




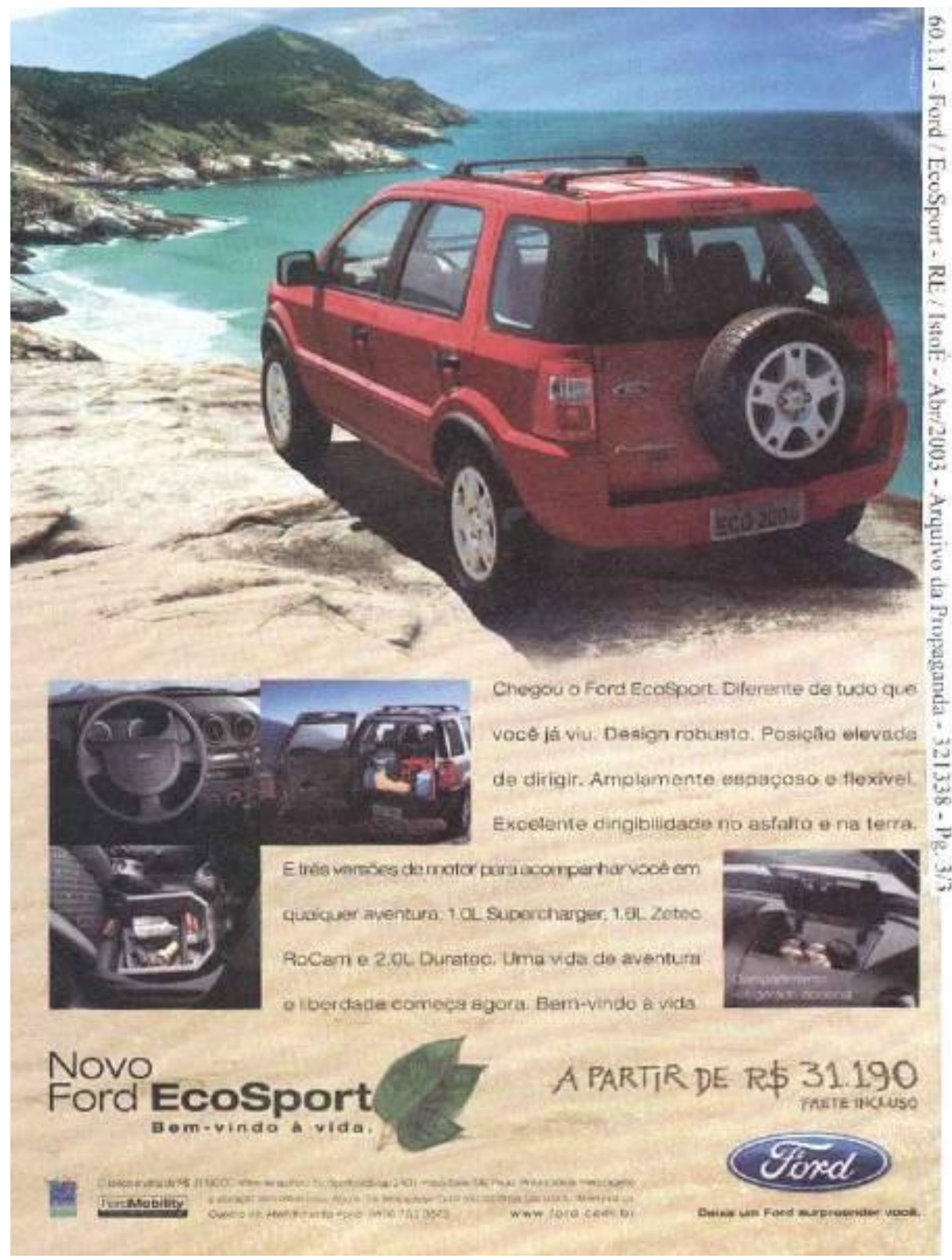


Análise do contexto

Ambiente externo

Em 2003 o Brasil atravessava um período de baixo crescimento, que se refletia nas vendas de automóveis. Analisando a tabela abaixo, com os números de vendas de automóveis desde 2003, verifica-se um volume próximo a um milhão de veículos, um número inferior ao registrado em 1997, 1.569.727 automóveis, recorde histórico. Recorde que foi quebrado somente em 2007.

Tabela IX

Mercado Automobilístico brasileiro

\begin{tabular}{|lrrrrr|}
\hline & 2003 & 2004 & 2005 & 2006 & 2007 \\
VENDAS DE AUTOMÓVEIS & 1.168 .681 & 1.258 .446 & 1.369 .182 & 1.556 .220 & 1.975 .518 \\
\hline
\end{tabular}

Fonte: ANFAVEA

Portanto, o EcoSport; fruto de planejamentos e investimentos em uma nova fábrica na Bahia, cujo início foi justamente em 1997, época que se vislumbrava um mercado promissor; nasceu em meio a um cenário muito competitivo. Contudo, desde o seu lançamento e até os dias de hoje, seu desempenho em vendas vem mostrando que o carro é um sucesso. Parte deste sucesso deveu-se a sua comunicação dinâmica e conectada com o público.

Análise do veículo (mídia)

A revista Veja, com uma tiragem semanal de mais de um milhão de exemplares, é há quarenta anos a principal revista do país, oferece notícias, entrevistas e reportagens. Seu público é de classe social A e B, constituindo-se portanto na melhor mídia impressa em termos de cobertura.

Em abril de 2003, os destaques da revista eram a guerra dos Estados Unidos da América contra o Iraque, os vintes anos de sucesso da cantora americana Madona, o casal Garotinho no governo do Estado do Rio de Janeiro e os cem dias do governo do presidente Luiz Inácio Lula da Silva. Na saúde, os destaques eram 
para as epidemias de dengue e febre amarela no Brasil, e na Ásia a síndrome respiratória aguda grave, SARS, sua sigla em inglês.

Análise do público

Conforme analisado no capítulo referente à cultura de consumo e o automóvel, o público, no ano de 2003, estava sob forte estresse dos grandes centros urbano e a falta de tempo para um equilíbrio entre a vida pessoal e o trabalho.

As incertezas globais com a guerra do Iraque, o medo das epidemias, os problemas do cotidiano, como violência, trânsito, poluição e a economia sem muita energia geravam um clima de pouco otimismo. Neste ambiente, a Ford lança o EcoSport, na mesma época em que a Honda lançava o Honda Fit, uma aposta no segmento de mini-vans, que não suplantou o carro da Ford.

\section{Análise do anúncio}

A primeira das cinco páginas que compõem o anúncio vem com uma única imagem, uma bela fotografia trazendo uma jovem em primeiro plano, boiando em uma praia de águas claras e paisagem paradisíaca, sobre a qual um texto vazado em branco ocupa o céu límpido do local, em total harmonia plástica com a foto.

A expressão de tranqüilidade e prazer da modelo reflete os benefícios de umas férias de verão. Para o leitor da revista, a imagem consegue transmitir toda essa paz e tranqüilidade estampada na face da jovem, além de despertar o desejo de viajar.

Neste momento, nenhuma assinatura, nenhum logotipo reclama a propriedade do anúncio, pelo repertório e pela linguagem da propaganda fica implícito que se trata de um anúncio, mas a ausência do anunciante a torna ainda mais instigante

O texto, ao alto, ocupa também posição de destaque, com tipos brancos sobrepondo-se no céu azul, em tamanho que permite uma leitura confortável, com bom espaçamento, atrai o leitor a decifrar o significado da imagem. 
Abaixo segue a transcrição do título e do texto da primeira página.

"Estatuto da sua nova vida

\section{Artigo I}

Fica decretado que todos os dias da semana,

inclusiva as terças-feiras,

mais cinzentas,

têm o direito de a converter-se

em manhãs de domingo."

O texto, remetendo a um estatuto, passa ao público uma impressão sobre o anunciante, certo tom de autoridade para contribuir com um ethos de credibilidade. Na segunda página, um novo artigo desse estatuto compõe com um entardecer nas montanhas, mais uma imagem de tranqüilidade, com mais uma modelo, agora deitada de olhos fechados, como que meditando sobre a relva. Ela convida as leitoras a se colocarem em sua posição, e ao mesmo tempo sugere uma segunda pessoa, ausente, como um companheiro de viagem tirando uma foto sua.

O prazer proporcionado pelas imagens, convidando a uma nova vida, sugerido pelo estatuto e a ausência da identidade do anunciante, instigam o público a continuar folheando as páginas da revista em busca de mais prazer e a solução do mistério.

\section{"Artigo II}

Fica decretado que,

a partir deste instante,

as janelas devem

permanecer o dia inteiro 
abertas para o verde"

A terceira página apresenta-se em três dobras com os dizeres:

"Bem vindo à vida... Chegou o Ford EcoSport"

Neste instante desvenda-se o mistério, surge o anunciante com sua marca e sua mercadoria prometendo uma nova vida.

Dois carros, duas situações. Um primeiro, vermelho, atravessando um riacho que deságua na provável praia da primeira fotografia, e um segundo, prata, imponente sobre uma montanha, com referencias à segunda fotografia. As duas localidades não demonstram caminhos apropriados para um automóvel qualquer chegar, sugerindo habilidades e funcionalidades específicas do modelo EcoSport para que ele chegasse onde as imagens o mostram. Em quadros menores, aparecem casais de jovens felizes aproveitando momentos de lazer com a natureza.

A quarta página traz o complemento do texto "Estatuto da sua nova vida":

"Artigo III

A palavra liberdade

será suprimida

dos dicionários.

A partir deste instante

será algo vivo,

como o fogo e o mar."

Ao fim traz a assinatura do autor, o poeta amazonense, Thiago Mello, agregando ao texto um endosso poético de fato. Uma credibilidade para a proposta de uma nova vida. O texto foi extraído do poema "Estatuto do homem", o qual é transcrito na íntegra abaixo: 
"Estatuto do homem

Artigo 1: Fica decretado que agora vale a verdade, agora vale a vida e de mãos dadas marcharemos todos pela vida verdadeira;

Artigo 2: Fica decretado que todos os dias da semana, inclusive as terças-feiras mais cinzentas, tem direito a converter-se em manhãs de domingo;

Artigo 3: Fica decretado que a partir deste instante, haverá girassóis em todas as janelas, que os girassóis terão direito a abrir-se dentro da sombra e que as janelas devem permanecer o dia inteiro abertas para o verde onde cresce a esperança;

Artigo 4: Fica decretado que o homem não precisará nunca mais duvidar do homem, que o homem confiará no homem como a palmeira confia no vento, como o vento confia no ar, como o ar confia no campo azul do céu;

Parágrafo único: O homem confiará no homem como um menino confia em outro menino;

Artigo 5: Fica decretado que os homens estão livres do julgo da mentira, nunca mais será preciso usar a couraça do silêncio nem armadura de palavras, o homem se sentará a mesa com seu olhar limpo porque a verdade passará a ser servida antes da sobremesa;

Artigo 6: Fica estabelecida durante dez séculos a pratica sonhada por Isaías que o lobo e o cordeiro pastarão juntos e a comida de ambos terá o mesmo gosto de aurora;

Artigo 7: Decreta e revogada, fica estabelecido o reinado permanente da justiça e da claridade, e a alegria será uma bandeira generosa para sempre desfraldada da alma do povo;

Artigo 8: Fica decretado que a maior dor sempre foi e será sempre não poder dar-se amor a quem se ama e saber que é a água que dá a planta o milagre da flor;

Artigo 9: Fica permitido que o pão de cada dia que é do homem o sinal de seu suor, mas que sobretudo tenha sempre o quente sabor da ternura;

Artigo 10: Fica permitida a qualquer pessoa, qualquer hora da vida o uso do traje branco;

Artigo 11: Fica decretado por definição que o homem é o animal que ama, e que por isso é belo, muito mais belo que a estrela da manhã;

Artigo 12: Decreta-se que nada será obrigado nem proibido, tudo será permitido, inclusive brincar com os rinocerontes e caminhar pelas tardes com imensa begônia na lapela;

parágrafo único, só uma coisa fica proibida, amar sem amor;

Artigo 13: Fica decretado que o dinheiro não poderá nunca mais comprar um sol das manhãs de todas, expulso do grande baú do medo, o dinheiro se transformará em uma espada fraternal para defender o direito de tentar e a festa do dia que chegou;

Artigo Final: Fica proibido o uso da palavra liberdade, a qual será suprimida dos dicionários e do pântano enganoso da dor, a partir deste instante, a liberdade será algo vivo e transparente como um fogo ou um rio, e a sua morada será sempre o coração do homem."

A utilização desse recurso da intertextualidade entre a linguagem publicitária e a linguagem poética não é novidade. Na verdade, resgatam-se aqui os primórdios da redação publicitária no Brasil, quando poetas, como Olavo Bilac, escreviam, com seus estilos literários, os textos para os anúncios do início do século XX. 
A quinta página fecha o anúncio mostrando o carro como protagonista da peça, num local supostamente de difícil acesso para um automóvel, com uma bela paisagem de praia ao fundo. Compondo o anúncio vêm alguns dados funcionais do carro, um texto, o preço de $\mathrm{R} \$ 31.190,00$ e um texto explicativo:

"Chegou o Ford EcoSport. Diferente de tudo que você já viu. Design robusto. Posição elevada de dirigir. Amplamente espaçoso e flexível. Excelente dirigibilidade no asfalto e na terra. E três versões de motor para acompanhar você em qualquer aventura: 1.0L Supercharger, 1.6L Zetec Roçam e 2.0L Durated. Uma vida de aventura e liberdade começa agora. Bem-vindo à vida."

\section{Percurso gerativo de significação}

Nesta análise do anúncio de lançamento do EcoSport o percurso gerativo de sentido seguirá do mais concreto ao mais abstrato. Ou seja, o ponto de partida é o anuncio de cinco páginas e o de chegada é o fundamento do posicionamento, que se desenvolve num enunciado, num briefing.

\section{Primeira página}

\section{Estrutura discursiva}

Componente sintático: o enunciador oculto, não revelado, que pode ser um único, ou mesmo um conjunto de legisladores. Ocultos também os registros de tempo e espaço, indicando uma debreagem enunciva, porém a imagem sugere uma enunciatária na figura da jovem mulher, que serve de alvo para projeções do leitor, e uma perpetuação do aqui e agora. Todos os dias da semana, daqui para frente, vão ser manhãs ensolaradas de domingo.

Componente semântico: identificam-se duas linhas isotópicas neste primeiro enunciado. A primeira aparece sob a forma do discurso publicitário, devido à imagem tomando toda a página em uma revista semanal, porém a leitura do texto remete a uma segunda linha isotópica, que segue o esquema de um discurso jurídico, legislando um novo estatuto, instituindo uma nova regra de comportamento para os dias da semana. Estas duas linhas não são conflitantes, pois fica clara a intencionalidade publicitária, que é a isotopia dominante. 
A imagem de uma jovem mulher boiando em águas claras de uma praia paradisíaca e o texto legislativo imprimem um querer-fazer, uma vontade de seguir a nova regra, não mais necessitando trabalhar durante a semana. A ausência do autor faz despertar o interesse na peça publicitária e a vontade de virar a próxima página para entender melhor a mensagem e descobrir quem é o anunciante, qual é a mercadoria.

\section{Estrutura narrativa de superfície}

Componente sintático: o enunciado da peça publicitária e sua imagem mostram um texto que implica uma sucessão de estado e transformação. Embora ausente o sujeito do fazer, este, por meio do "estatuto da sua nova vida" transformou a situação do sujeito de estado, em princípio em disjunção, tendo que trabalhar durante a semana, colocando-o em conjunção com o objeto de desejo, o lazer na praia, a despreocupação, o ócio no paraíso todos os dias.

Componente semântico: o programa narrativo então é um programa da aquisição onde os valores modais do objeto são de querer e poder fazer, descritos na peça pelo desfrute na praia, a liberdade que o estatuto deu para uma nova vida, na qual o prazer é o meio e a finalidade.

\section{Estrutura narrativa profunda}

Componente semântico: a categoria do nível fundamental nesta primeira página é o trabalho versus o descanso, o lazer. Sendo que o trabalho, no caso do texto analisado, é disfórico, enquanto o lazer é eufórico. O lazer, portanto, é o termo valorizado e desejado.

Vida (dia a dia)

Trabalho Lazer

"Escravo"

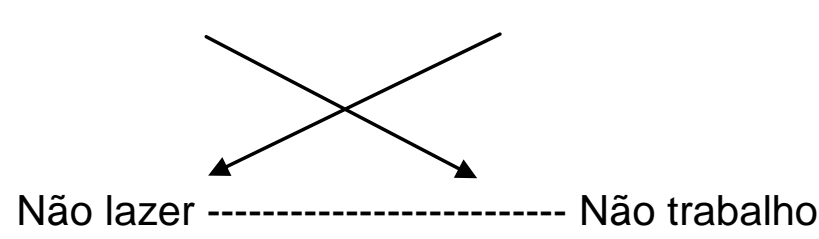

"Nova vida"

Morte (inativo) 
Componente sintático: Expressa a transformação do estado disfórico para o eufórico: dever fazer (trabalhar) $=\rightarrow$ poder fazer (lazer) $=\rightarrow$ querer fazer (lazer).

\section{Segunda página}

\section{Estrutura discursiva}

Componente sintático: continua o legislador oculto a proferir o ato II e a enunciatária, uma jovem mulher, presente na imagem aproveitando o "estatuto da nova vida", deitada na relva numa paisagem campestre projeta em si o público leitor. O momento é o agora e o local é um campo com muito verde.

Componente semântico: é pura continuidade, criando ainda mais suspense. Agora a mulher está deitada na relva, numa paisagem de muito verde, conotando muita paz e a tranqüilidade da manha de domingo. O campo é apresentado na imagem sem um traço de civilização, indicando, em seu contraponto com a cidade, segurança e tranqüilidade, além de toda a mitologia relativa ao contato com a natureza.

No enunciado o termo "as janelas devem permanecer abertas o dia inteiro para o verde", como continuidade da página anterior, mostra que o objeto valorizado denotado é o lazer com a natureza, mas também pode ser conotada a tranqüilidade da não necessidade de se fechar as janelas. Um ponto importante é que o texto foi editado do poema anteriormente citado, no texto original o verde referido simboliza a esperança, mas no anúncio o verde é a natureza.

\section{Estrutura narrativa de superfície}

Componente sintático: Esta página também indica uma finalização de uma sucessão de estado de disjunção para uma transformação que leva o sujeito do estado para uma conjunção com o objeto de valor, uma nova vida cheia de ar puro, muito verde e da tranqüilidade da vida no campo. 
Componente semântico: O programa narrativo também é um programa da aquisição, no qual os valores modais do objeto são de querer e poder fazer, descrito na peça pelo desfrute do campo, da natureza e da tranqüilidade.

\section{Estrutura narrativa profunda}

Componente semântico: a categoria do nível fundamental nesta segunda página continua sendo o lazer, que suporta a "nova vida". Sendo que o artificial, no caso do texto analisado, é disfórico, enquanto a natureza é eufórica. O verde, simbolizando a natureza e a vida no campo, portanto é o termo valorizado e desejado.

\section{Terceira página}

\section{Estrutura discursiva}

Componente sintático: o autor, neste momento, se dirige diretamente ao leitor, não havendo mais o recurso da projeção por meio da jovem na praia ou no campo, ele dá boas vindas à vida, a "nova vida" do leitor e apresenta aqui e agora o novo EcoSport.

Componente semântico: Neste instante é revelado, no âmbito da publicidade, qual é a mercadoria. O EcoSport se apresenta na praia e no campo, em situações que os carros comuns não poderiam estar, fazendo uma associação com a primeira página da praia e a segunda do campo. A "nova vida", então, para ser vivida precisa de um carro como o EcoSport, afim de levar o leitor até ela. O carro é seu passaporte.

Todo o investimento de valor feito nas páginas anteriores é depositado no carro como o instrumento que vai capacitar o herói a conquistar a sua nova vida de lazer e tranqüilidade. As imagens menores representam o leitor aproveitando os locais de praia e campo para os quais o carro teve a competência de levá-lo. 


\section{Estrutura narrativa de superfície}

Componente sintático: esta página indica um estado de conjunção que a aquisição da competência do EcoSport pode propiciar. O sujeito do estado está em conjunção com o objeto de desejo, sua "nova vida".

Componente semântico: O programa narrativo também é um programa da aquisição no qual é enfatizado o valor modal de poder fazer, descrito na peça pela competência do EcoSport.

\section{Estrutura narrativa profunda}

Componente semântico: a categoria do nível fundamental nesta terceira página é a oposição entre vida antiga e vida nova, cheia de lazer. Neste texto, velha vida, é disfórica, enquanto nova é eufórica. A nova vida como síntese das outras páginas, é o termo valorizado e desejado.

Ciclo

Rotina Aventura

Tédio

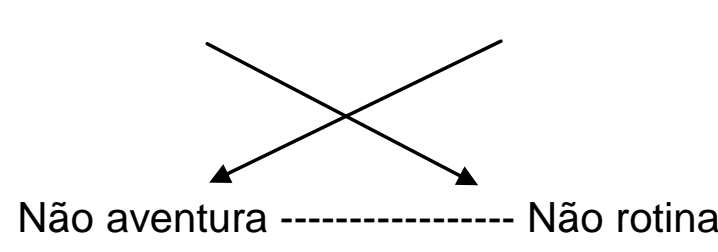

Lazer

Monotonia

Componente sintático: Expressa o estado eufórico de poder fazer e querer fazer: poder fazer (aventura) $=\rightarrow$ querer fazer (lazer). 


\section{Quarta página}

\section{Estrutura discursiva}

Componente sintático: volta o legislador, agora não mais oculto, para proferir $\mathrm{O}$ ato III. Este se revela como Thiago de Mello, o poeta. O enunciatário, um jovem saltando numa praia ao entardecer, é uma imagem projetada de todo aspiracional do leitor, público alvo para o EcoSport, juventude, vitalidade e a cambalhota com símbolo da conquista, da comemoração de uma aventura atingida.

Componente semântico: retorna com o discurso legislador, fecha o apelo emocional da publicidade, revelando, por meio do autor, o enunciado como um poema, revestindo-o com mais emoção. A imagem cheia de beleza e contemplação denota toda a energia da juventude; muito mais que mera disponibilidade para aproveitar a vida, uma verdadeira vontade de fazê-lo. O leitor, público alvo para a mercadoria, projeta-se no jovem, sabendo que a sua vontade de se aventurar, levando consigo pessoas de que ele gosta, torna-se possível com o EcoSport.

$\mathrm{Na}$ imagem do anuncio chama atenção à capacidade que o jovem tem de dar uma cambalhota, numa associação clara com a capacidade do carro de levar as pessoas para os lugares a que os outros carros não têm acesso. Mas, além disso, deixa clara também a grande felicidade de ter conseguido, ao fim do dia (e ao fim da seqüência de anúncios), concluir a sua aventura, o seu "gol". Cambalhotas são, em muitos casos, manifestações que os jogadores de futebol se valem para comemorar a feitura de um gol.

\section{Estrutura narrativa de superfície}

Componente sintático: o enunciado desta quarta página e sua imagem compõe um texto que pressupõe uma sucessão de estado e transformação. $O$ sujeito do fazer (agora, com a revelação do poeta, o sujeito do fazer recai sobre o EcoSport) transformou a situação do sujeito de estado, em principio em disjunção, sem possibilidade de desfrutar a vida, colocando-o em conjunção com o objeto de desejo, a aventura conquistada.

Componente semântico: O programa narrativo é, então, um programa da aquisição, onde os valores modais do objeto são de poder fazer e querer, descritos 
na peça pela possibilidade que o EcoSport proporcionou ao leitor de se aventurar no campo ou na praia e aproveitar a sua nova vida em boa companhia, pois as personagens das primeiras imagens entram no enredo final como coadjuvantes da aventura do rapaz da cambalhota.

\section{Estrutura narrativa profunda}

Componente semântico: a categoria do nível fundamental nesta quarta página é uma síntese de todas as páginas anteriores; a liberdade de poder e a vontade de querer fazer, no estado final, já cumprida com êxito a missão. Daí a comemoração, a vitória. A categoria semântica é a derrota, como uma vida rotineira, em oposição à vitória, como uma nova vida de aventuras. Em tal quadro, a derrota é disfórica, enquanto a vitória é eufórica. A vitória, aqui, é um valor de uso, um poder fazer o que se quiser fazer.

Condição

Derrota Vitória

Perda

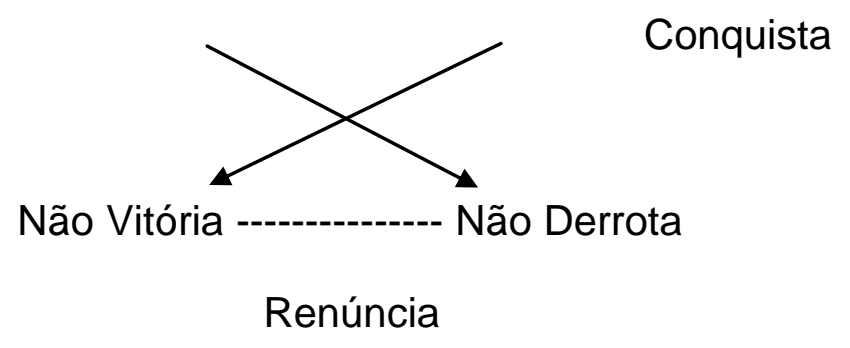

Componente sintático: expressa a passagem do estado disfórico para o eufórico: dever fazer (rotina) $=\rightarrow$ poder fazer (liberdade) $=\rightarrow$ querer fazer (aventura).

Quinta página

Estrutura discursiva

Componente sintático: $\mathrm{O}$ ator enunciador dirige-se diretamente ao leitor, público alvo da mercadoria, apresentado-lhe as funcionalidades do carro. $O$ 
enunciado "chegou o Ford EcoSport" demonstra o registro de tempo do agora. O local é o cenário de desejo, onde o leitor gostaria de estar. O enunciatário, claro em toda linguagem publicitária, é o público receptor, possível comprador do carro.

Componente semântico: fechando o anúncio, a isotopia da linguagem publicitária agora está totalmente dominante, utilizando argumentos técnicos e funcionais para convencer o público. É o momento de chamar à razão. Vários itens denotativos informam sobre as competências funcionais do carro, mas outras tantas, como "design robusto", "excelente dirigibilidade... na terra" e "uma nova vida de aventura e liberdade", levam a conotar que o carro é um verdadeiro utilitário esportivo, coisa que o carro não é. O produto, agora revelado, omite características importantes, como tração nas quatro rodas, que ele não possui, necessárias para dar conta da promessa de aventura e liberdade.

O preço, muito atraente porque se referente ao modelo mais simples, com motor 1.0L, chama a atenção e desperta o interesse de compra. Com o intuito de levar o público até o ponto de venda, esta prática comercial de colocar o preço da versão mais barata e mostra uma imagem da mais completa não deveria ser permitida, pois cria-se a ilusão de que o produto mostrado é vendido por tal preço.

Por fim, as assinaturas com o slogan do carro "Bem-vindo à vida" e o logotipo da empresa montadora, a Ford, dando consistência à linguagem publicitária, fechando assim o anúncio.

\section{Estrutura narrativa de superfície}

Componente sintático: o enunciado desta última página e sua imagem compõem um texto pelo qual se presume que o leitor acaba de conquistar seu prêmio. Está implícito que havia um estado de disjunção, que com a chegada do carro e a suposta compra se transformou num estado de conjunção com a "nova vida", cheia de "aventura e liberdade". O sujeito do fazer, neste momento, não deixa dúvidas: é o EcoSport. Para entrar em conjunção com o objeto de valor, é necessário comprá-lo, por, no mínimo, $\mathrm{R} \$ 31.190,00$.

Componente semântico: o programa narrativo permanece como o da página anterior, é um programa da aquisição onde os valores modais do objeto são de 
poder fazer e querer, descritos na peça pela aventura e pela liberdade que o EcoSport oferece ao leitor para que este aproveite a sua nova vida.

\section{Estrutura narrativa profunda}

Componente semântico: a categoria do nível fundamental nesta quinta página é a oportunidade que expressa, num nível mais concreto, a compra. Ou seja, uma oportunidade eufórica que é dada pela Ford para comprar o EcoSport. A oportunidade de compra está expressa nos termos do texto e no preço que chama para a ação se consumar.

\section{Interesse}

Inconveniência -------------- Oportunidade

Postergação

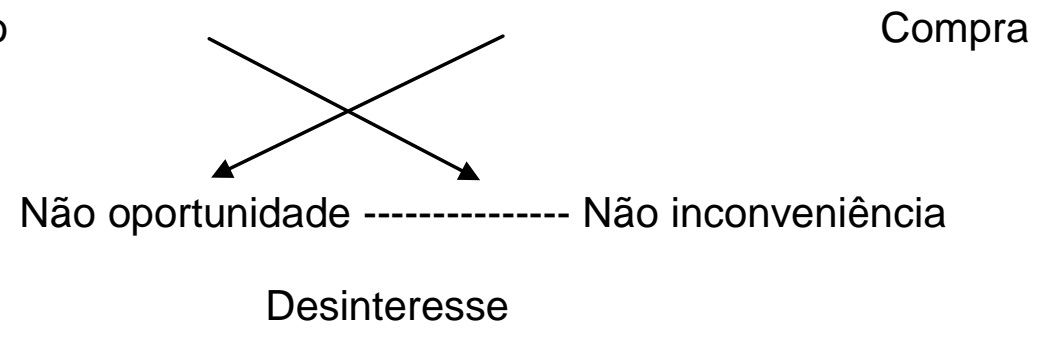

Componente sintático: expressa o estado eufórico de possuir um EcoSport: poder fazer (recursos) $=\rightarrow$ querer fazer (compra).

O resumo das cinco páginas no tocante ao conceito fundamental fica assim:

Primeira página: Lazer

Segunda página: Lazer

Terceira página: Aventura

Quarta página: Conquista

Quinta página: Oportunidade 
Analisando-se o conteúdo fundamental do conjunto das cinco páginas que formam o anúncio da revista Veja, e considerando-se que esta seqüência de imagens e enunciados formam um todo, ou pretendem contar uma única estória, verifica-se a intenção de "vender" um poder e querer fazer, ou seja, não é suficiente ter a liberdade para escolher. Uma "nova vida", com uma grande carga positiva empenhada para este termo, é mais do que ter a liberdade de tirar alguns dias de folga, é aproveitar esta folga se aventurando, saindo da rotina. Experimentar novos caminhos, sentir a exclusividade de estar onde a maioria não pode chegar. Este é o significado final das cinco páginas, o poder e o querer aproveitar a vida viajando para onde poucos podem chegar, para praias e montanhas, onde a natureza é generosa para quem lá pode estar. E tal poder é justamente representado pelo EcoSport, o veículo que possibilita a mobilidade, mas é também a vontade de aproveitar a vida, de estar em lugares restritos poucos, de levar consigo pessoas com as quais se quer dividir esta experiência.

O EcoSport é um convite à aventura, não uma aventura desmedida, irresponsável, mas sim aquela que se contrapõe à rotina do dia-a-dia de trabalho, uma escapada, uma fim de semana em contato com a natureza, uma aventura desejada, uma aventura imaginada.

É bem provável que boa parte dos compradores do EcoSport não o utilize para ir às montanhas, nem tampouco às praias desertas, mas isto é, sem dúvida, o objeto de desejo para o qual a Ford apontou na apresentação do carro. Portanto, a essência da identidade da marca EcoSport está centrada na possibilidade de poder aproveitar a vida se aventurando em boa companhia por praias e campos com acesso interdito à maioria. Ou, num único conceito fundamental, a aventura.

Olhando as peças como um todo, observa-se uma seqüência retórica que visa à persuasão de um leitor, público-alvo de marketing, predominantemente masculino. A primeira e a segunda página captaram a atenção deste leitor com as jovens, relaxadas e entregues às sensações da natureza; a terceira é o centro que explica, ainda no nível emocional, como e por que elas estavam lá, quem as levou, mostrando o carro sem o motorista, deixando ao público-alvo o espaço para se enxergar como o protagonista dessa estória; a quarta revela uma projeção clara do 
público masculino se regozijando pela euforia por ter conseguido sua aventura. A última trata da chamada para a ação, a venda em si, com os argumentos racionais.

Construindo o enunciado do posicionamento para o briefing desta campanha tem-se o seguinte:

Semântica narrativa $=$ conceito fundamental: Aventura

Quadrado semiótico: quadrante do utópico

Sintaxe narrativa: querer fazer $=>$ poder fazer

$\mathrm{PN}=\mathrm{F}$ (Sujeito do fazer $=>$ (sujeito do estado conjunção objeto de desejo)

Sistema de valor: aventura, estilo de vida aventureiro, natureza.

Sintaxe discursiva: tempo presente; sujeito de fazer = EcoSport; sujeito de estado = Público alvo, homens e mulheres com espírito de aventura; espaço = natureza, praia ou campo.

Semântica discursiva: busca da aventura sonhada de quem vive no dia a dia da cidade.

Manifestação na superfície do signo, enunciado do posicionamento:

EcoSport, um novo veículo, com design de utilitário esportivo, para homens e mulheres com espírito jovem que deseja a aventura e o lazer para viver uma nova vida.

Slogan: Bem-vindo à vida.

Comentários

Como já foi exposto, os números de vendas do EcoSport demonstram um sucesso inquestionável. Mas, a sua imagem no público não obedeceu totalmente ao posicionamento pretendido pela montadora. No tocante ao público alvo, desde o seu lançamento até os dias de hoje, quase cinqüenta por cento dos compradores são mulheres, segundo pesquisa contratada exclusivamente pelas montadoras, a chamada New Car Buyer Survey, ou estudo sobre compradores de carros novos, a qual, pelo seu caráter extremamente confidencial, na pôde ser anexada a esta pesquisa. 
O fato de o público ser quase metade composto de mulheres indica que a aventura, desejo do público masculino, cedeu espaço para a mente feminina. Para as mulheres, como já estudado no capítulo referente à cultura de consumo e do automóvel, o principal atributo procurado neste tipo de automóvel - utilitário esportivo - é a segurança na cidade. As mulheres valorizam o design do carro, sua forma robusta e a sua maior altura em relação ao solo. Ou seja, uma valoração muito mais prática do que utópica.

A experiência na comunicação da indústria automobilística diz que não se deve dirigir exclusivamente e explicitamente às mulheres, utilizando seus estereótipos e seus valores, pois às mulheres isto não agrada. Lançar um carro exclusivo para as elas, em cores chamativas e funcionalidades específicas, provavelmente não faria sucesso, pois, num universo aparentemente masculino, o dos automóveis, elas não querem (com razão) ser segregadas, mas sim fazer parte dele.

Desse modo, a Ford, ao falar do seu EcoSport para o público masculino, com os valores próprios deste, não prejudica o interesse das mulheres, as quais se sentem também atraídas pelo aspecto prático do carro.

Segundo momento de análise de posicionamento

No segundo semestre de 2005, a Ford lança no mercado a versão do Eco Sport com motor flexível, chamado EcoSport flex, isto é, com a capacidade de rodar tanto com gasolina quanto com álcool combustível. Neste momento, a montadora retoma a propaganda em mídia impressa, conforme a série de anúncios abaixo. 
Julho de 2005, revista Isto É. Página tripla, sendo esta a parte dupla.

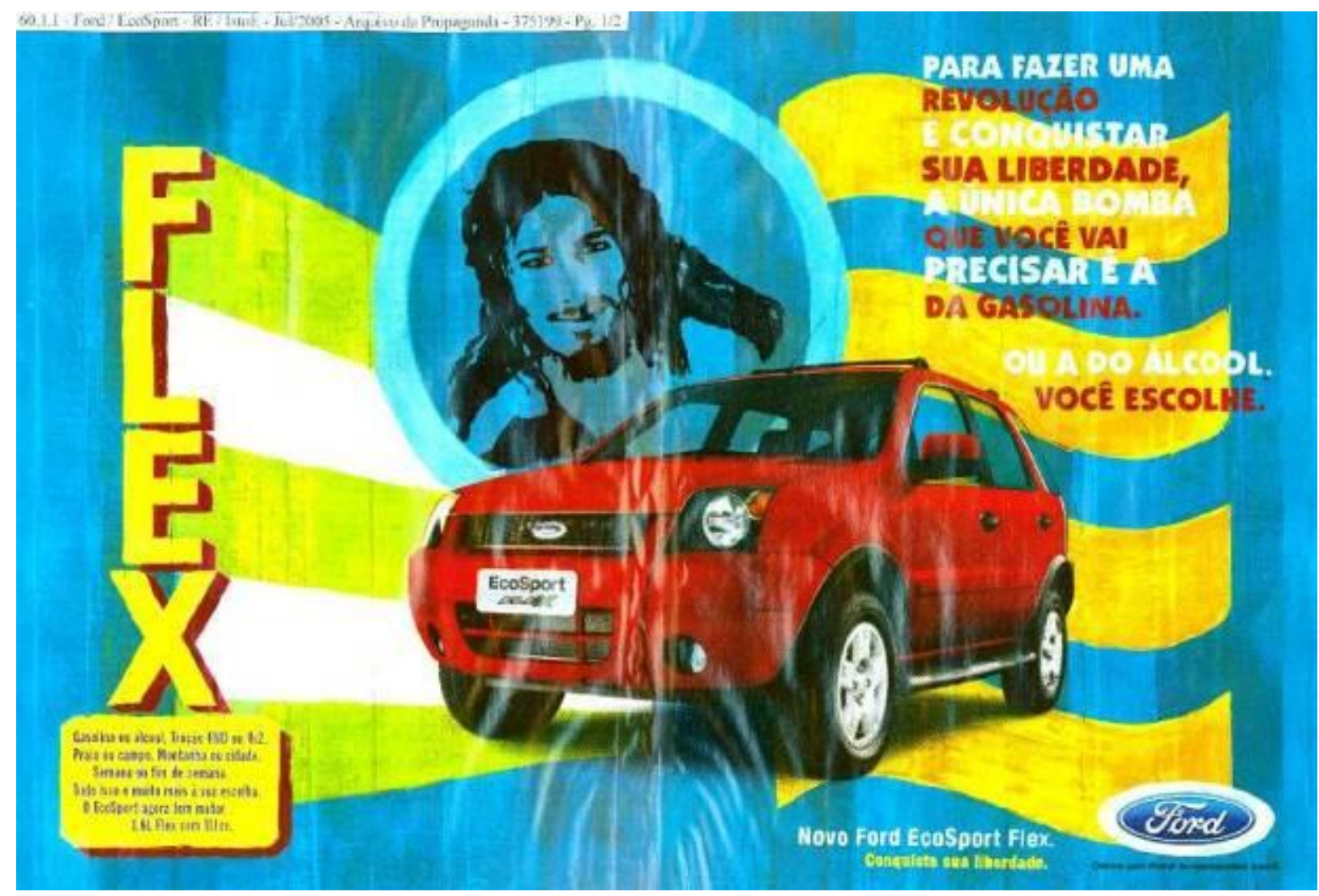

Continuação da página tripla. 


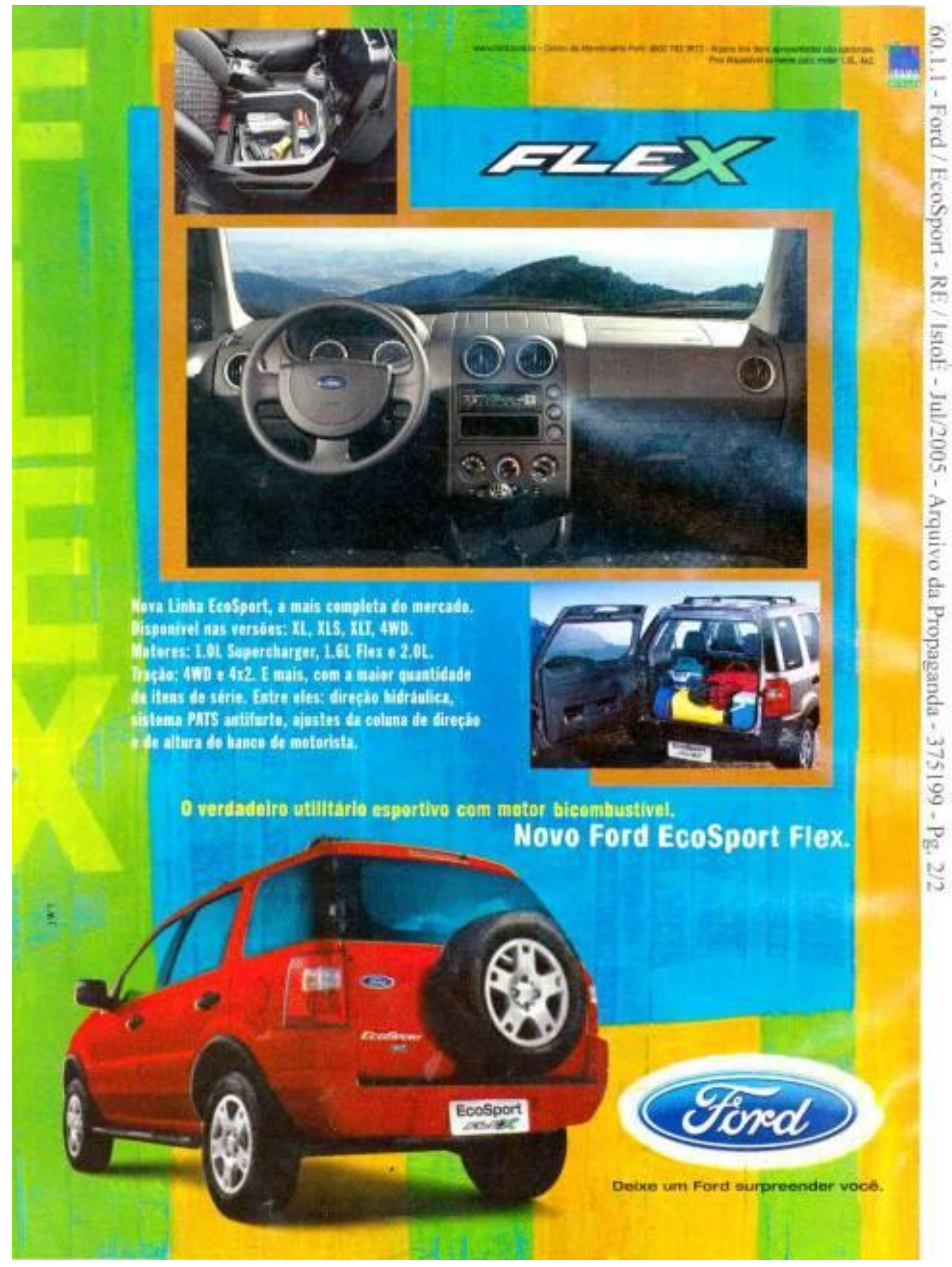


Análise do contexto

Em 2005 o mercado automobilístico brasileiro iniciava um período de lenta recuperação. Neste ano a indústria automobilística vendeu 1.369 .182 carros, segundo a ANFAVEA, sendo destes, 46.084 de EcoSport. Um número significativo mostrando a vitalidade deste modelo.

Uma novidade, que iria modificar o mercado brasileiro de veículos automotores, foi a introdução de uma nova tecnologia de alimentação dos motores que permitia a utilização de gasolina ou álcool combustível em qualquer proporção no tanque do carro. Deixando o proprietário com a opção de escolher o combustível ora mais econômico. Num curto espaço de tempo as montadoras lançaram seus modelos com esta tecnologia e o mercado começou a procurar veículos flexíveis.

O momento era de elevação dos preços do petróleo e, conseqüentemente, de uma alta nos preços da gasolina. A possibilidade de poder abastecer com qualquer combustível afastava de vez os problemas com o álcool combustível, que era bem mais barato. Porém se o carro fosse exclusivamente à álcool poderia sofrer com os problemas de disponibilidade deste combustível.

\section{Análise do anúncio}

Ao folhear a revista chega-se a uma página dupla com desenhos em cores fortes e chamativas com um carro em vermelho ao centro e a palavra "FLEX" em letras grandes, escrita na vertical à esquerda. Acima do carro um desenho de um rapaz de cabelos e barba compridos emoldurado por um círculo azul. A peça como um todo segue a representação de um grafite de rua, uma manifestação. $O$ carro, um EcoSport, chama a atenção por parecer não pertencer ao desenho. Fica de imediato claro que se trata de uma propaganda de automóvel e para o público alvo, o do EcoSport.

A presença de um texto à direita parece ser a única forma de desvendar o que está sendo anunciado, este diz: "Para fazer uma revolução e conquistar a sua liberdade, a única bomba que você vai precisar é a da gasolina. Ou a do álcool. Você escolhe." O suspense supostamente ainda continua, embora boa parte do público, que está bem informado sobre a tecnologia de combustível flexível, já tenha presumido que se trata do EcoSport com motor flex. 
Para esclarecer de vez, não deixando dúvidas, e fazer a entrega dos atributos funcionais, no canto inferior esquerdo uma caixa com mais um texto diz: "Gasolina ou Álcool. Tração 4WD (four wheel drive - tração nas quatro rodas). Praia ou campo. Montanha ou cidade. Semana ou fim de semana. Tudo isso e muito mais à sua escolha. O EcoSport agora tem motor 1.6 Flex com 111CV."

Assinando a peça tem-se: "Novo Ford EcoSport Flex. Conquiste a sua liberdade". E, por fim, a assinatura da montadora: "Ford. Deixe um Ford surpreender você".

$\mathrm{Na}$ próxima página, imagens de partes específicas do carro sobrepõem desenhos coloridos que lembram uma bandeira, inclusive, devido ao verde e amarelo, a bandeira brasileira. Um novo texto aprece quase ao centro: "Nova linha EcoSport, a mais completa do mercado. Disponível nas versões: XL, XLS, XLT e 4WD. Motores 1.0L Supercharge, 1.6L Flex e 2.0L. Tração: 4WD e 4X2. E mais, com a maior quantidade de itens de série. Entre eles: direção hidráulica, sistema PATS antifurto, ajuste da coluna de direção e de altura do banco do motorista."

Para fechar o anúncio, mais um texto: "O verdadeiro utilitário esportivo com motor bicombustível. Novo Ford EcoSport Flex".

\section{Percurso gerativo de significação}

\section{Estrutura discursiva}

Componente sintático: o autor enunciador fala diretamente com o leitor enunciatário, projetado na propaganda na forma do desenho do jovem cabeludo.

Componente semântico: identifica-se uma isotopia de revoluções contestadoras. As cores e formas de grafite aludindo a uma bandeira, o desenho do jovem de cabelos e barbas compridos, mais o texto principal, valendo-se de termos como "fazer revolução", "conquistar sua liberdade" e "bomba", criam no público receptor a imagem de atitudes revolucionárias. O carro, vermelho, ao centro, é quem recebe os atributos de revolucionário, mas de outra revolução, a tecnológica, que permite ao consumidor escolher entre gasolina ou álcool. O tema das escolhas fica evidente nos enunciados, como gasolina ou álcool, praia ou campo, montanha ou 
cidade. A suposta economia de combustível, proveniente da escolha, não é o fator principal. O EcoSport é o carro que dá ao consumidor a possibilidade de escolher.

\section{Estrutura narrativa de superfície}

Componente sintático: o enunciado da peça publicitária e sua imagem mostram um texto que implica uma sucessão de estado e transformação. O sujeito de estado apresenta uma disjunção com a possibilidade de abastecer o carro com gasolina ou álcool. O sujeito do fazer, Ford, apresenta o novo EcoSport Flex, e, por meio deste, é possível ao sujeito do estado, o público-alvo para esta mercadoria, ficar livre para escolher como quer abastecer. O sujeito de estado entra em conjunção com o objeto de desejo, no caso, a liberdade de escolha do combustível.

Componente semântico: o programa narrativo é um programa da aquisição, no qual os valores modais do objeto são de poder fazer (devido à capacidade do EcoSport) e de querer fazer, exercitando a possibilidade de escolha, ou seja, de abastecer com o combustível que mais lhe interessar.

\section{Estrutura narrativa profunda}

Componente semântico: a categoria do nível fundamental deste anúncio em página tripla é a de privação versus liberdade, sendo que a primeira é disfórica, enquanto a segunda é eufórica. A liberdade de escolha é o termo valorizado e desejado.

\section{Limite}

Privação -------------------------- Liberdade

Imposição

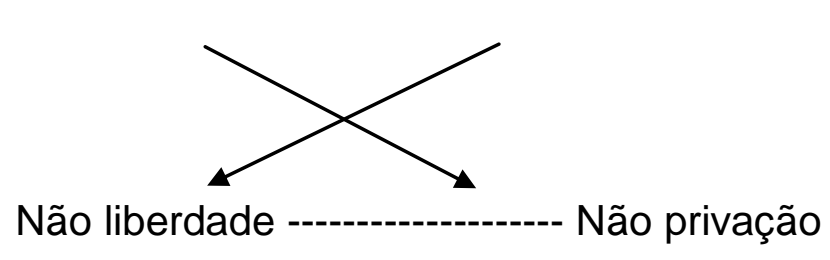

Escolha 
Componente sintático: expressa a transformação do estado disfórico para o eufórico: não poder fazer $=\rightarrow$ poder fazer $=\rightarrow$ querer fazer (escolha).

Manifestação na superfície do signo, enunciado do posicionamento:

EcoSport, com design de utilitário esportivo, para homens e mulheres com espírito jovem que desejam a praticidade e a possibilidade de escolher seus caminhos e a forma como abastece o seu carro.

O Conceito fundamental é a liberdade de escolha.

Slogan: Conquiste sua liberdade.

\section{Comentários}

A Ford adicionou uma nova funcionalidade ao EcoSport, a qual passou a ser comum a todos os outros veículos. Para trabalhar isso na comunicação, a montadora valeu-se da dicotomia apresentada na campanha de lançamento, entre praia e campo, e a expandiu para outros tantas características, a fim de poder concentrar-se na questão do bi-combustível como o principal chamariz do carro.

Posicionar o carro como flexível, a ponto de dar liberdade para o consumidor escolher o que quer e como quer justifica-se pelo momento. Mas com certeza houve uma mudança no conceito fundamental, bem como na forma. O que antes era fotos e cenários bucólicos, agora são desenhos e cores berrantes. A mensagem, embora importante para o público feminino, continua predominantemente masculina.

Em dezembro de 2005, seis meses depois desta propaganda, a Ford volta a mídia impressa com uma nova campanha para falar sobre o motor flex, oferecendo a possibilidade de abastecer com gasolina ou álcool.

A peça reforça a liberdade de escolha, mas não usa mais a isotopia das revoluções; ao contrario volta aos cenários da natureza, ressaltando o caráter flexível do carro, com a dicotomia praia ou campo, além do abastecimento de combustível. Neste anúncio, a escolha está entre fica no sofá de casa ou assistir ao pôr-do-sol ao vivo. 


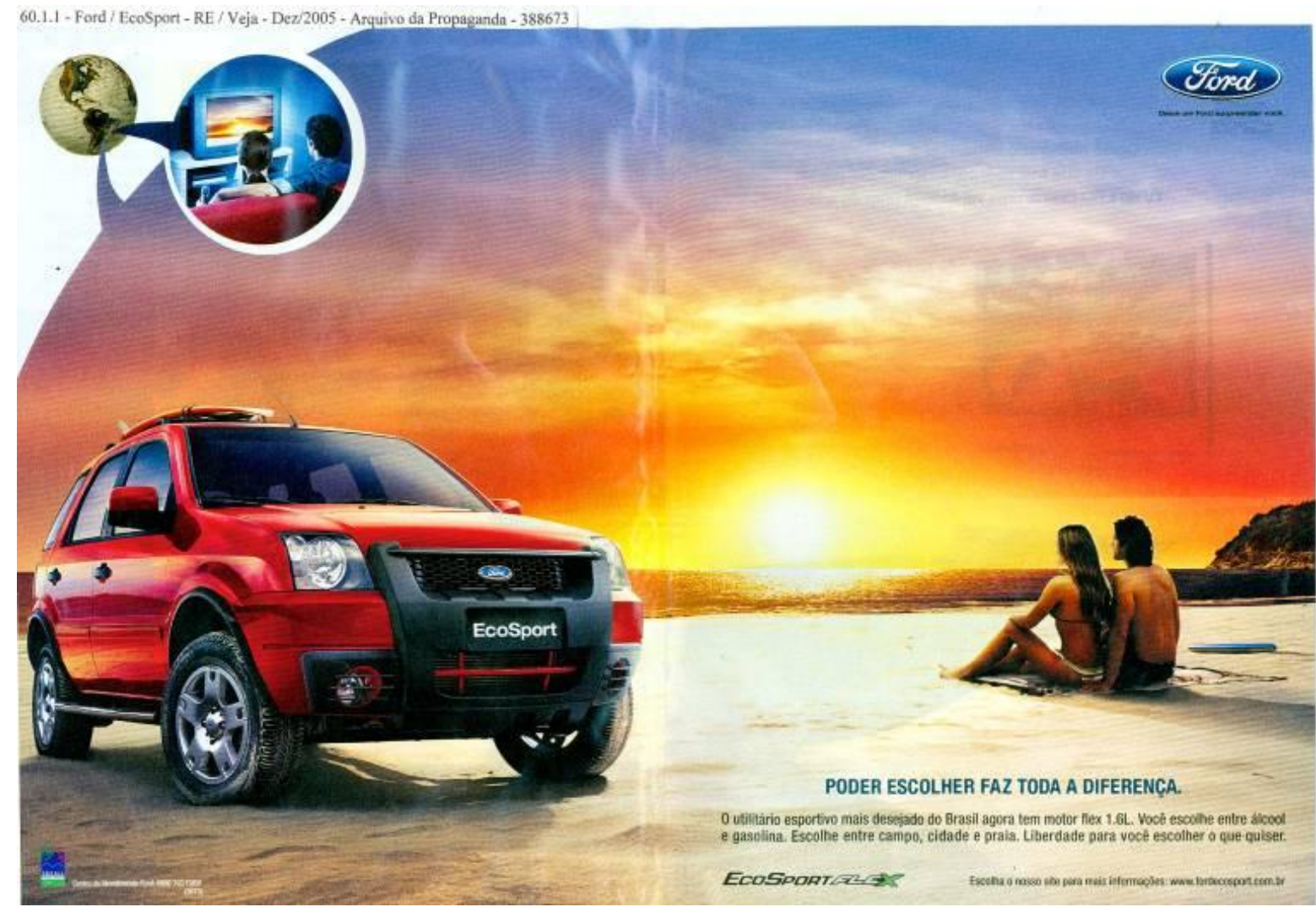

Veja - Dezembro de 2005

Terceiro momento de análise de posicionamento

O terceiro e último momento da análise do posicionamento do EcoSport refere-se ao lançamento da versão re-estilizada, ocorrido em outubro de 2007. A campanha, veiculada na televisão e na mídia impressa, pretendia transmitir a idéia de que é possível sentir, no dia-a-dia da cidade, o bem estar atribuído ao mundo fora de estrada. 


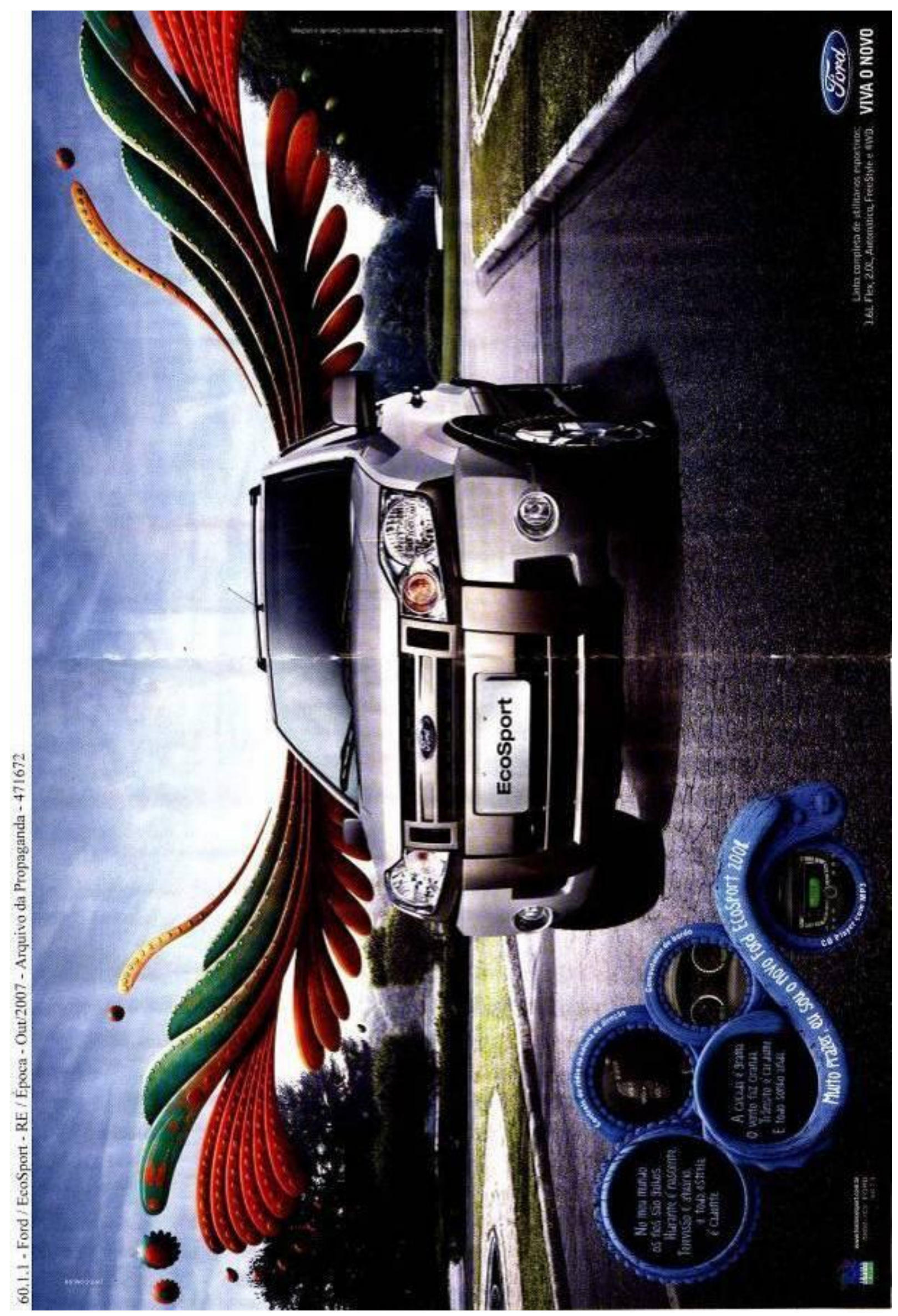


Análise do contexto

Em 2007 o mercado automobilístico brasileiro estava em seu melhor momento. As vendas cresciam mês a mês com a expansão do credito e a melhora das condições econômicas do Brasil. Por outro lado, o tema do aquecimento global e as péssimas condições de trânsito das grandes capitais começavam a preocupar o público. Nos Estados Unidos da América, com a alta do preço dos combustíveis, os grandes utilitários esportivos estavam em queda, e a imagem de carros beberrões e poluentes fez com que as montadoras repensassem seus portfólios de produtos, optando por produzir carros menores e mais econômicos.

Aqui no Brasil essa situação não chegou a ser observada, mesmo porque a frota brasileira, além de ser composta em sua maioria por carros pequenos, já era, em 2007, mais da metade bicombustível. Por aqui era mesmo o trânsito o principal vilão, e muitos já se referiam ao automóvel como "o cigarro do milênio".

\section{Análise do anúncio}

O anúncio analisado é de página dupla, divulgado na revista Época de outubro de 2007. A imagem central predomina em toda a peça, trata-se de do novo EcoSport, ano-modelo 2008, com grandes asas, que aparecem desenhadas sobre ele. A paisagem de entorno, ao contrário de outras propagandas da marca, não retrata mais o campo ou praias paradisíacas, mas o parque de uma cidade, ou seja, uma paisagem urbana.

No canto inferior esquerdo, pequenos textos aparecem dentro de molduras circulares. Os textos voltam a utilizar recursos de intertextualidade entre poesia e publicidade, tal como na primeira peça analisada. O carro agora é o enunciador de um mundo próprio, o mundo do EcoSport. Por meio de um fazer persuasivo, o carro faz uma leitura da cidade sob sua ótica "fora de estrada", conotando que ser fora de estrada é sua essência, mesmo que ele viva só na cidade. Os textos seguem uma isotopia poética e imaginária, na qual as metáforas predominam.

"No meu mundo os fios são galhos.

Hidrante é nascente.

Televisão é aquário, e toda estrela é cadente. 

A calçada é grama.
O vento faz ciranda.
O trânsito é cardume, e todo sonho anda.

Muito prazer, eu sou o novo Ford EcoSport 2008"

O anúncio termina com a assinatura da montadora com seu novo slogan "Ford. Viva o novo".

A imagem também adota uma intertextualidade entre 0 encantamento, 0 maravilhoso e a realidade. Com referências imagéticas extraídas do universo fabuloso uma asa foi desenhada por sobre uma fotografia do carro em uma rua, criando uma situação de encantamento e de liberdade.

\section{Percurso gerativo de significação}

\section{Estrutura discursiva}

Componente sintático: O autor enunciador neste caso é o próprio EcoSport falando diretamente com o enunciatário leitor. A enunciação ocorre com o actante eu, carro, no espaço aqui e no momento agora. O espaço é o mundo do EcoSport. O tempo é o dia-a-dia.

Componente semântico: as intertextualidades entre poesia e publicidade e a fantasia e realidade dão o tom à peça. Há uma clara referência a um mundo fabuloso nos traço dos desenhos que emolduram os blocos de texto e, principalmente, nas asas do carro. O próprio discurso na voz do carro também contribui para este cenário de encantamento. $O$ espaço utilizado para compor o tema é um território mágico entre a fantasia e a realidade que é o mundo do EcoSport. Um mundo onde é possível sentir sensações, aromas e visuais da natureza dentro do dia-a-dia urbano.

A peça denota um mundo de fantasia, porém sua construção conota que, se o EcoSport vê a cidade como se fosse uma praia, campo, a natureza enfim, é porque ele é assim, porque são estes os seus valores. Isto tudo é um convite à imaginação 
do público para se imaginar fora de estrada dentro da cidade. E, para tanto, não é necessário comprar os utilitários esportivos sofisticados, que na realidade enfrentam as vicissitudes de rodar fora de estrada, mas com um preço muito alto. Basta imaginar, com sua alma de aventureiro, que é possível sentir o bem-estar da natureza no ambiente urbano. As asas sobre o carro são um símbolo cultural que representa um "cavalo alado" da modernidade, que transporta as pessoas para um mundo melhor.

\section{Estrutura narrativa de superfície}

Componente sintático: $O$ enunciado da peça publicitária e sua imagem mostram um texto que implica uma sucessão de estado e transformação. $O$ sujeito do fazer, o EcoSport, transforma a paisagem urbana em natureza, fazendo com que o sujeito de estado, o público, deixe o dia-a-dia monótono e sem graça da cidade, um estado disfórico para um estado de conjunção com o objeto de desejo, o prazer de viver na natureza.

Componente semântico: O programa narrativo é um programa da aquisição no qual o valor modal do objeto é de poder fazer, devido a capacidade do EcoSport de voar com as asas imaginárias para além do dia-a-dia.

\section{Estrutura narrativa profunda}

Componente semântico: a categoria do nível fundamental deste anúncio é a de realidade versus fantasia. Sendo que a realidade é disfórica, enquanto a fantasia é eufórica. A fantasia, como possibilidade de sonhar com uma vida de bem estar, é o termo valorizado e desejado.

Realidade Fantasia

Razão

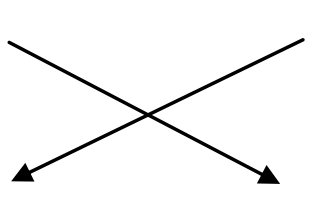

Sonho

Não fantasia Não realidade 
Componente sintático: expressa a transformação do estado disfórico da realidade para o eufórico da fantasia: não poder fazer $=\vec{\rightarrow}$ poder fazer $=\vec{\rightarrow}$ querer fazer (fantasiar).

Manifestação na superfície do signo, enunciado do posicionamento:

EcoSport, com design de utilitário esportivo, para homens e mulheres com espírito jovem que desejam fantasiar o seu dia-a-dia tornando-o agradável ao percorrer o caos da cidade.

O Conceito fundamental é a fantasia.

Slogan: Muito prazer eu sou o novo Ford EcoSport 2008.

\section{Comentários}

Embora os signos de liberdade continuem presentes, fica evidente que a liberdade na é um fim, e sim um meio para se atingir o que se deseja. No caso deste anúncio, a liberdade que se tem com o carro, que inclusive possui asas imaginárias, serve para tirar o público de um dia-a-dia monótono, com o estresse da cidade, para outro mundo, o mundo do EcoSport. Neste mundo imaginário, as coisas do dia-a-dia se transformam em coisas da natureza e tudo fica bem.

Verificando-se a análise da nova cultura do desejo de Melinda Davis, observase um movimento na publicidade dos últimos anos enaltecendo o sonho, o bemestar, pois o desejo fundamental para nossa sobrevivência é a paz de espírito (DAVIS, 2002). Foi nessa linha que a Ford conduziu, intencionalmente ou não, o atual posicionamento do seu carro.

Concluindo a análise sincrônica do posicionamento da marca Ford EcoSport, desde o seu lançamento até hoje, verifica-se que houve sempre mudança na forma e também no conteúdo da mensagem publicitária, atualizando o posicionamento conforme os valores da cultura no momento das veiculações.

Resumo: 
Posicionamento em 2003

Manifestação na superfície do signo, enunciado do posicionamento:

EcoSport, um novo veículo, com design de utilitário esportivo, para homens e mulheres com espírito jovem que desejam a aventura e o lazer para viver uma nova vida.

Conceito fundamental: Aventura

Slogan: Bem-vindo à vida.

Posicionamento em 2005

Manifestação na superfície do signo, enunciado do posicionamento:

EcoSport, com design de utilitário esportivo, para homens e mulheres com espírito jovem que deseja a praticidade e a possibilidade de escolher seus caminhos e a forma como abastece o seu carro.

O Conceito fundamental é a liberdade de escolha.

Slogan: Conquiste sua liberdade.

Posicionamento em 2007

Manifestação na superfície do signo, enunciado do posicionamento:

EcoSport, com design de utilitário esportivo, para homens e mulheres com espírito jovem que desejam fantasiar o seu dia-a-dia tornando-o agradável ao percorrer o caos da cidade.

O Conceito fundamental é a fantasia.

Slogan: Muito prazer eu sou o novo Ford EcoSport 2008. 


\section{CONCLUSÕES E RECOMENDAÇÕES PARA OS GESTORES DE}

\section{MARCAS}

Relembrando: a identidade da marca e, conseqüentemente, o seu posicionamento, é formada pelas interações com três sistemas levantados por Semprini, ou seja, o contexto, a enciclopédia da produção e a enciclopédia da recepção. Qualquer variação em um destes sistemas vai exigir do gestor de marcas um estudo para uma possível variação na comunicação para o público.

Em geral, quando ocorre uma modificação nas funcionalidades da mercadoria, ou mesmo na sua embalagem, é mais comum verificar uma modificação na mensagem publicitária para dar conta de anunciar determinado atributo novo. Quando os objetivos empresariais exigem uma postura diferente do mercado, como promoções para diminuir estoques, também são comuns as variações nas mensagens. Por certo muita coisa muda caso a empresa decide ofertar a mercadoria para outro tipo de público que não o anteriormente planejado.

O que raramente se vê é uma modificação na mensagem publicitária, fruto de uma atualização do posicionamento, devido a mudanças no contexto social. A experiência tem como paradigma que os valores do público receptor não sofrem alterações do dia para a noite, e que, por conseguinte, sua percepção das coisas também não se altera com facilidade.

Com isto firmou-se um pensamento no mundo das estratégias de marketing segundo o qual o posicionamento de marca deve ser sempre mantido, que a forma de comunicar pode sofrer algumas atualizações, mas, uma vez feito um esforço para colocar a marca numa determinada posição na mente do consumidor, não se deveria mudá-la, sob pena de se perder a imagem conquistada.

Essa pesquisa propôs a hipótese de que o gestor da marca deve pensar o posicionamento da marca como um processo, que sofre uma constante tensão entre manter-se ou modificar-se, de acordo com as alterações no nível do contexto, muito além das modificações já praticadas, em razão de modificações no produto ou nas estratégias da empresa. 
As modificações que possam vir das variáveis relativas à enciclopédia da produção já fazem parte da administração de marketing, e têm uma relação muito forte com o ciclo de vida do produto. Por outro lado, as oscilações da enciclopédia da recepção acontecem em função do contexto, da cultura, da sociedade de consumo como um todo. Neste sentido, segundo os estudos de Bauman e Lipovetsky, os valores que norteiam o comportamento do humano e, conseqüentemente, do consumidor, na cultura de consumo, são fugazes.

Para efeito desta pesquisa, isolando-se a produção e a recepção, sustenta-se que o posicionamento de marca deve ser flexível para acompanhar a fluidez de valores e costumes que se observa na sociedade de consumo contemporânea.

Para verificar essa hipótese foram analisadas as publicidades da marca Ford EcoSport, a fim de se extrair o seu posicionamento em três fases de sua vida no mercado: no lançamento, na sua maturidade de mercado e nos dias atuais. Estas análises foram embasadas na teoria semiótica greimasiana do percurso gerativo de significação. Os resultados mostram uma atualização do posicionamento do EcoSport já em 2005, dois anos após o lançamento e uma nova atualização em 2007.

No seu lançamento, o EcoSport foi posicionando como um carro para se aventurar. Seu slogan convidava o público à nova vida. Para a montadora, a aventura era o conceito valorizado no momento, e a comunicação trabalhou para dar esta personalidade ao carro, mesmo não possuindo ele as funcionalidades necessárias para uma verdadeira aventura, porém seu design era totalmente adequado à proposta da comunicação, tornando a mensagem crível.

Em 2005, com um novo atributo, a possibilidade de o carro ser abastecido por gasolina ou álcool, a comunicação modificou um pouco o posicionamento a fim de refletir o principal benefício da nova funcionalidade, ou seja, a possibilidade de escolher o combustível. Essa liberdade, que já estava um pouco presente na primeira campanha, agora assume ares revolucionários.

Mas foi em 2007, adequando-se às demanda do público por um antídoto contra o estresse, que veio a grande atualização no posicionamento. A fantasia, o sonho, passa a ser um conceito muito mais valorizado do que a aventura. $O$ carro assume essa nova personalidade. Os signos da sua publicidade nada mais têm a 
ver com cenários paradisíacos, mas sim com uma paisagem urbana com ilustrações fantasiosas. Essa dinâmica do posicionamento vem garantindo ao EcoSport uma imagem jovem e conectada com os valores da sociedade de consumo.

Não foi só o conceito fundamental que a comunicação da Ford atualizou. A forma das mensagens também passou por uma mudança drástica nos três momentos analisados. No lançamento, os espaços utilizados eram os locais aos quais o carro poderia levar o consumidor. No segundo momento, era um espaço indefinido, no qual o carro em si cedia lugar para a mensagem do FLEX. No terceiro, o espaço fantasioso era algo imaginado pelo personagem do carro.

O EcoSport é um carro com cinco anos de mercado, e que, embora as versões mais vendidas não possuam funcionalidades de fora de estrada, continua sendo um grande sucesso em vendas. Seu segmento de mercado, os utilitários esportivos, vêm ganhando a cada ano novos modelos e novas marcas. Outras carrocerias e designs na mesma faixa de preço também vieram para dividir espaços com o carro da Ford, mas este manteve suas vendas, mostrando que está em sintonia com os desejos do seu público. Boa parte deste sucesso está na sua comunicação, que se flexibilizou, de acordo com as mudanças nos valores da cultura e, por conseguinte, do público receptor.

Da aventura para a liberdade, e, por fim, para a fantasia. O que chama a atenção nestes três conceitos, quando colocados sob uma perspectiva semiótica da valorização do consumo construída por Floch, é que eles têm um traço em comum. Todos os três fazem parte do quadrante da utopia, contrariamente ao da prática. Os três conceitos utilizados na comunicação do carro são valores existenciais, referentes ao estilo de vida, ao comportamento almejado pelo proprietário.

Aventura, liberdade e fantasia evocam facilmente imagens que sobem nas estruturas do percurso gerativo de significado, constituindo signos belos e atraentes como as imagens da campanha de lançamento, ou outras tantas que o EcoSport apresentou desde o seu lançamento (ver anexo).

Neste sentido é possível concluir que a flexibilização do posicionamento pode ter limites de segurança. Estes limites são os quadrantes do quadrado semiótico de Floch. Não são determinantes, são orientativos, pois o que determina a extensão da mudança é a cultura. Em todos os casos, a análise do gestor da marca é 
fundamental. Este deverá considerar todas as variantes da identidade da marca, com atenção especial para o contexto, e tirar suas próprias conclusões. 


\subsection{Pontos fortes e limitações}

Esta metodologia de análise semiótica permite desconstruir o signo da publicidade e identificar o conceito fundamental da identidade de um marca. Este conceito é o ingrediente principal do posicionamento de marca. O caminho inverso, ou seja, a construção do enunciado do posicionamento a ser incorporado ao briefing para a agência de publicidade também é possível, tendo sido já trabalhado na dissertação de mestrado deste pesquisador.

Os pontos fortes desta metodologia semiótica aplicados ao marketing são: a verificação da pertinência das estratégias da empresa, das características do produto, do público receptor e do contexto social sob uma mesma perspectiva isotópica de sentido; a possibilidade de escolha de um conceito diferente da concorrência e mais atrativo aos desejos e anseios do público e, por fim, estar sempre sintonizado com os valores da cultura de consumo.

Pertinência

A metodologia permite reduzir a identidade da marca a um conceito fundamental, uma palavra, como aventura, liberdade, poder, robustez, economia, etc.. Este termo, que aqui se chama essência da marca para o posicionamento, seria como o seu DNA. Em todas as ações da empresa relativas a esta marca e suas mercadorias este conceito deve estar presente. A empresa, a mercadoria e sua comunicação devem emitir este conceito em todos os contatos com clientes, imprensa, fornecedores e funcionários.

Com isso, a imagem da marca torna-se coesa e coerente, possibilitando a todos, em qualquer situação, perceber e reconhecer a promessa que a marca se dispôs a fazer. Obviamente, a mercadoria e a empresa devem entregar a promessa funcional para o cliente, fazendo com que este tenha uma experiência positiva.

Diferenciação

A análise feita aqui com o EcoSport pode e deve ser feita com os principais concorrentes de uma marca com a finalidade de identificar suas essências, para então escolher, dentro das possibilidades da mercadoria, um conceito diferenciado para se destacar perante o público. 


\section{Fluidez}

A metodologia convida o gestor da marca a estudar o contexto cultural, além da enciclopédia da produção e da recepção, a fim de identificar momentos em que certos valores dispersos começam a mostrar uma tendência, e assim flexibilizar a comunicação na forma e no conteúdo, indo ao encontro dos desejos do público.

Neste ponto, junta-se à análise semiótica a teoria da formação dos significados e valores na cultura, agregar e fluir, de McCracken (McCRACKEN, 2006), já abordada no capítulo sobre posicionamento dinâmico de marcas.

A constante vigília dos movimentos de significados na cultura de consumo é uma tarefa intrínseca do processo de posicionamento dinâmico de marcas. Tal processo está em constante tensão entre solidificar e fluir, cabendo ao gestor a sensibilidade na análise e a atitude no gerenciamento da marca para colocá-la em destaque positivo perante o público almejado.

\section{Limitações}

As limitações observadas no processo são três: a falta de familiaridade com assuntos de ordem sociológica por parte de algumas empresas; a grande dependência da sensibilidade cultural do gestor de marcas e a falta de bibliografia sobre 0 assunto.

As empresas, em sua maioria, têm seus conhecimentos focalizados na tecnologia de produção, de distribuição ou de prestação de serviço. O mundo empresarial tem uma linguagem própria do comércio e das técnicas, e, em geral, não se aventura muito no universo cultural e sociológico, o que traz dificuldades no dialogo entre o gestor da marca e os demais gestores, como agências, e, sobretudo, dificuldades para avaliar as mudanças possíveis nos valores e significados no ambiente sócio-cultural.

O próprio gestor tem, predominantemente, sua formação na área de administração de empresas e marketing, cujos conteúdos não privilegiam disciplinas sociais e culturais.

Por fim, há uma falta de bibliografia, principalmente ligada à gestão de marcas, sobre a aplicação das ciências sociais, como sociologia, antropologia e 
semiótica no marketing. O pouco que existe está em língua estrangeira, e não consta nas bibliografias das escolas de administração e marketing.

Essas limitações, no entanto, podem servir como estímulo a futuras pesquisas sobre posicionamento de marca, bem como sobre a aplicação da semiótica no marketing no Brasil. 


\subsection{Recomendações finais}

Hoje em dia, as mudanças ocorrem no mundo em velocidade exponencial. Muitas das profissões de hoje, como agricultura orgânica, e-bussines e nanotecnólogo não existiam há dez anos. Para o ano de 2010 está previsto que a maior população que fala a língua inglesa estará na China. (WWW.shifthappens.wikispace.com)

Segundo a Anatel - Agencia Nacional de Telecomunicações, O Brasil possui mais de 133 milhões de celulares em funcionamento, representando $72,3 \%$ da população do país. O celular hoje é um dos objetos de desejo dos jovens, e, para muitos, mais do que o automóvel.

Com um mundo assim em constante mudança. Com as pessoas procurando paz de espírito, estressadas por um mundo imagético, com velhos diplomas para enfrentar novas profissões que surgem ano a ano, com problemas ambientais, como o aquecimento global e a crise dos combustíveis fósseis, e com os meios de comunicação pela internet expandindo conhecimentos e opiniões é praticamente impossível planejar a médio e longo prazo.

Elaborar um posicionamento de marca e sustentá-lo por anos significa correr o risco de se ter uma imagem ultrapassada e em dissintonia com o público. O caso estudado, um automóvel, por ser um bem de consumo durável, ainda guarda certa longevidade nos conceitos. O EcoSport mudou seu posicionamento a cada dois anos. Mas para muitos outros produtos de consumo e serviços a necessidade de se adequar a dinâmica dos significados é ainda maior.

Como recomendação final, fica a proposta de criação de um novo curso e uma nova profissão, a de Gerente de Significados, responsável pelo processo de significação das marcas e mercadorias. 


\section{Bibliografia e materiais publicados}

AAKER, David A. Marcas brand equity: gerenciando o valor da marca. São Paulo: Negócio Editora, 1998.

Administração estratégica de mercado. Porto Alegre,

Bookman, 2001.

Positioning your product: readings in marketing strategy.

USA: The scientific press, $2^{\text {nd }}$. Edition, pag. $193-198,1989$.

ANFAVEA. Anuário da industria automobilística brasileira. São Paulo, 2008, em http://www.anfavea.com.br/anuario.html

ARBIX, Glauco, ZILBOVICIUS, Mauro. De JK a FHC: a reinvenção dos carros. São Paulo, Scritta, 1997.

ARAUJO, Emília. A mobilidade como objecto sociológico, Universidade do Minho, 2004 em http://hdl.handle.net/1822/3913.

BARROS, Diana, Teoria semiótica do texto. São Paulo: Ática, 2007.

BARTHES, R. Elementos de semiologia. São Paulo: Cultrix, 1971.

BAUDRILLARD, Jean. O sistema dos objetos. São Paulo: Perspectiva, 2000.

BAUMAN, Zygmund. Vida Liquida. Rio de Janeiro: Jorge Zahar, 2007. Identidade. Rio de Janeiro: Jorge Zahar, 2005.

CANEVACCI, Massimo. Antropologia da comunicação visual. Rio de Janeiro: DP\&A, 2001.

CARRASCOZA, João. A evolução do texto publicitário. São Paulo: Futura, 1999.

CARREIRA, J. C. A linguagem da marca: um enfoque semiótico do marketing, in Thesis -Revista dos alunos de pós graduação da Casper Líbero,ano III, 6, 2002.

\section{A contribuição da semiótica no processo de}

posicionamento de mercado de automóvel. 2003. (Dissertação de mestrado. Faculdade Cásper Líbero). 
CARVALHO, Nelly. Publicidade: a linguagem da sedução. São Paulo: Ática, 2002 ,

CHALHUB, Samira. A metalinguagem. São Paulo:Ática, 1997.

COELHO NETTO, J. Teixeira, Semiótica, Informação e Comunicação. São Paulo: Perspectiva, 2001.

COSTA, Cristina. Ficção, comunicação e mídias, São Paulo: Editora SENAC, 2002.

DAVIS, Melinda. A nova cultura do desejo. Rio de Janeiro: Records, 2003.

Di NALLO, E. Meeting points: soluções de marketing para uma sociedade complexa. São Paulo: Cobra, 1999.

DUCROT, O., TODOROV, T. Dicionário enciclopédico das ciências da linguagem. São Paulo: Perspectiva, 2001.

ECO, Umberto. Como se faz uma tese. São Paulo: Perspectiva, 2002.

ELLWOOD, lain. O livro essencial das marcas: tudo o que você precisa saber, em mais de 100 técnicas para aumentar o valor das marcas. São Paulo: Clio Editora, 2004.

FEATHERSTONE, Mike. Cultura de consumo e pós-modernismo. São Paulo: Studio Nobel, 1995.

FIORIN, J. L. Elementos de análise do discurso. São Paulo: Contexto, 2001.

FLOCH, Jean-Marie. Semiótica, marketing y comunicación; bajo los signos, las estrategias. Barcelona: Paidós, 1993.

Visual identities. London: Continuum, 2000.

FONTENELE, Isleide. O nome da marca: McDonald's, fetichismo e cultura descartável. São Paulo: Boitempo, 2006.

GIUCCI, Guillermo. A vida cultural do automóvel: percursos da modernidade cinética. Rio de Janeiro: Civilização Brasileira, 2004.

GREIMAS, A J. \& COURTÉS J. Dicionário de semiótica. São Paulo: Cultrix, 1979. 
Semântica estrutural. São Paulo: Cultrix, 1976.

Semiótica e ciências sociais. São Paulo: Cultrix, 1981.

.Os atuantes, os autores e as figuras, In: Semiótica narrativa e textual. São Paulo: Cultrix, 1997.

HALL, Stuart. A identidade cultural na pós-modernidade. Rio de Janeiro: DP\&A, 2006.

HAUG, Wolfgang Fritz. A crítica estética da mercadoria. São Paulo: UNESP, 1997.

HEILBRUNN, Benoit. A logomarca, São Leopoldo: Editora Unisinos, 2004.

HOLT, Douglas. Como as marcas se tornam ícones: os princípios do branding cultural. São Paulo: Cultrix, 2005.

HOOLEY, G \& SAUNDERS, J. Posicionamento competitivo: como estabelecer e manter uma estratégia de marketing no mercado. São Paulo: Makron, 1996.

KAPFERER, Jean-Noel. Strategic brand management. 2nd ed. New York: Free Press, 1992.

KELLER, K. L. Strategic Brand management: building, measuring and managing brand equity. Upper Saddle River: Prentice Hall, 2003.

KOTLER, P. Administração de marketing: análise, planejamento, implementação e controle. 12a .. ed. São Paulo: Atlas, 2006.

Marketing para o século XXI: como criar, conquistar e dominar mercados. São Paulo: Futura, 2001.

. Marketing insights from A to Z: 80 concepts every manager needs to know. New Jersey: John Wiley \& Sons, 2003.

INTERBRANDS.http://www.interbrand.com/images/studies/O_Poder_das_Mar cas_na_Am\%C3\%A9rica_Latina_2008.pdf.

LARAIA, Roque. Cultura: um conceito antropológico. Rio de Janeiro: Jorge Zahar, 2007. 
LATINI, Sydney. A implantação da industria automobilística no Brasil: da substituição de importações ativa à globalização passiva. São Paulo: Alaúde, 2006.

LENCASTRE, Paulo, Gestão da marca: curso ministrado na ECA - USP, São Paulo, 2005.

LÉVY, Pierre. Cibercultura, São Paulo: Editora 34, 1999. . O que é o virtual, São Paulo: Editora 34, 1996.

LEVITT, T. A imaginação de marketing. São Paulo: Atlas, 1990.

LIPOVETSKY, Gilles. A felicidade paradoxal: ensaio sobre a sociedade de hiperconsumo. São Paulo: Companhia das letras, 2007.

MADIA, F. Marketing pleno. São Paulo, Makron, 1999.

MAFFESOLI, M. O tempo das tribos: o declínio do individualismo nas sociedades de massa. Rio de Janeiro, Forense Universitária, 2000.

MAINGUENEAU, D. Os termos-chave da analise do discurso. Lisboa: Gradiva, 1997.

Análise de textos de comunicação. São Paulo: Cortez, 2005.

McCRACKEN, Grant. Cultura \& consumo: novas abordagens ao caráter simbólico dos bens e das atividades de consumo. Rio de Janeiro: Mauad, 2003.

Culture and consumption II: marketing, meaning and brand management. Bloomington: Indiana University Press, 2005.

. Flock and Flow: Predicting and managing change in a dynamic marketplace. Bloomington: Indiana University Press, 2006.

NÖTH, W. Panorama da semiótica: de Platão a Pierce. São Paulo: Annablume, 1995.

A semiótica no século XX. São Paulo: Annablume, 1996.

PEREZ, Clotilde, Signos da marca: expressividade e sensorialidades. São Paulo: Thomson Learning, 2004.

PROPP, V.I. Morfologia do conto maravilhoso. Rio de Janeiro: Forense, 1984. 
RANDAZZO, S. A criação de mitos na publicidade. Rio de Janeiro, Rocco, 1997.

RIES, A. \& TROUT, J. Posicionamento: a batalha pela sua mente. São Paulo: Pioneira, 1996.

SANDMANN, Antônio. A linguagem da propaganda. São Paulo: Contexto, 2000.

SANTO, Ivan (org.). Os sentidos da publicidade: estudos interdiciplinares. São Paulo: Thomson Learning, 2005.

SEMENIK, R. \& BAMOSSY, G.. Princípios de marketing: uma perspectiva global. São Paulo: Makron, 1996.

SEMPRINI, Andréa. Marche e mondi possibili: um approccio semiótico al marketing della marca. Milano: FrancoAngeli, 1993.

Marca: del prodotto al mercatto della marca alla societa. Milano: FrancoAngeli, 1996.

La marca postmoderna: potere e fragilità della marca nelle società contemporanee. Milano: FrancoAngeli, 2006.

SCHMITT, Bernd H. Marketing experimental. São Paulo: Nobel, 2002.

SCHULTZ, TANNENBAUM, LAUTERBORN. O novo paradigma do marketing: como obter resultados mensuráveis através do uso do database e das comunicações integradas de marketing. São Paulo: Makron, 1994.

TEIXEIRA, Sergio. Em busca do carro do futuro. Revista Exame, São Paulo, Ed.Abril, 24.01.2008. Na internet: http://portalexame.abril.com.br/revista/exame/edicoes/0910/tecnologia/m0149913.ht $\mathrm{ml}$

TROUT, Jack. The new positioning: the latest on the world's \#1 business strategy. New York: McGraw Hill, 1996.

UMIKER-SEBEOK, J. Marketing and Semiotics, new directions in the study of sign for sale. New York: Mouton de Gruyter, 1987.

WOMACK, James, JONES, Daniel \& ROSS, Daniel. A máquina que mudou o mundo. Rio de Janeiro: Campus, 1992. 


\section{GLOSSÁRIO}

Mercado $\mathrm{O}$ mercado consiste em todos os consumidores potenciais que compartilham de uma necessidade ou desejo específico, dispostos e habilitados para fazer uma troca que satisfaça essa necessidade ou desejo.

Indústria: Grupo de vendedores de veículos automotores novos, formado por montadoras e importadores operando no Brasil.

Marketing: Primeiramente verificaremos a definição formal da American Marketing Association: "Marketing é uma função organizacional e um conjunto de processo que envolve a criação, a comunicação e a entrega de valor para os clientes, bem como a administração do relacionamento com eles, de modo que beneficie a organização e seu público interessado."

Administração de Marketing: A definição formal é de Kotler (2006: 4): "arte ou ciência da escolha de mercados-alvos e da captação, manutenção e fidelização de clientes por meio da criação, da entrega e da comunicação de um valor superior para o cliente."

Processo tradicional de Administração de Marketing (Kotler, 2001:.46-47):

$$
\begin{aligned}
& P M=>S D P=>M M=>I=>C \\
& P M=\text { Pesquisa de mercado } \\
& \text { SDP = Segmentação, Definição de mercado-alvo e Posicionamento } \\
& M M=\text { Mix de Marketing (produto, preço, praça e promoção) } \\
& I=\text { Implementação } \\
& C \text { = Controle }
\end{aligned}
$$


Target ou Mercado-alvo: é uma parcela escolhida do mercado, para a qual se destinará o produto. Primeiro avalia-se várias parcelas baseadas em três fatores: tamanho e crescimento potencial; potencial de lucro e requisitos de competência da empresa, ou seja, objetivos e recursos disponíveis. Posteriormente seleciona-se uma ou mais parcelas, seguindo três estratégias: indiferenciação, diferenciação e concentração.

Mercadoria: O conceito é o mesmo do produto ou serviço que é feito para ser trocado, assim, adota-se a seguinte definição: a mercadoria é algo que pode ser oferecido para satisfazer a uma necessidade ou desejo.

Valores de uso: É o benefício que uma mercadoria, por meio de suas funcionalidades e características técnicas, proporciona para seu consumidor. No caso do automóvel, é a valorização deste como meio de transporte, ou seja, conforto, dirigibilidade, segurança etc.

Valores de troca: No contexto desta pesquisa, refere-se aos valores monetários envolvidos na comercialização de uma mercadoria, onde de um lado temos o produtor com o objetivo da venda para obtenção do lucro, de forma que, para a empresa, concretizada a venda encerra-se o processo de valorização. Do outro lado temos o consumidor, que avalia o bem desejado de acordo com uma pressuposição de utilização, que é o inicio do processo para realização do seu fim no uso. Neste caso, o consumidor, antes da efetivação da compra, pode somente imaginar o valor de uso: "o valor de uso teve, tendencialmente, um papel somente como aparência. É o estético no sentido mais amplo: a manifestação sensível e o sentido do valor de uso separam-se aqui do objeto" (HAUG, 1997:127). Pode-se então dizer que há uma dupla funcionalidade, uma "prática" (valor de uso) e outra "estética" (valor de base ou simbólico).

Valores de base ou simbólicos: No caso desta pesquisa, são os valores de identidade do proprietário projetados no automóvel - sua posição social, sua 
virilidade ou feminilidade, entre outros tantos, que se opõem aos valores de uso e influenciam diretamente na valorização de troca.

Semiótica greimasiana: A semiótica greimasiana tem como objetivo buscar o sentido dos textos ${ }^{1}$. Greimas desenvolveu um método de análise de discurso a partir de um conceito de narração. Esse trabalho, influenciado por Propp, levou-o a identificar formas universais de organização da narrativa dos textos. Essas formas são as estruturas que proporcionam a construção do sentido e da significação de uma determinada forma significante.

Isotopia: A isotopia é a recorrência do mesmo traço semântico ao longo de um texto que permite delimitar a significação deste, oferecendo ao leitor um plano para compreensão desejada.

Retórica: "A retórica é acima de tudo uma técnica que deve permitir a quem a possua atingir, dentro de uma situação discursiva, o alvo desejado; ela tem, portanto um caráter pragmático: convencer o interlocutor da justeza de uma causa" (DUCROT e TODOROV, 2001:79).

Ethos: Conceito proveniente da retórica de Aristóteles descreve a imagem que, implicitamente, um orador dava de si através de sua maneira de falar para corresponder à conjuntura ideológica de certa platéia.

\section{Significado:}

Significação: 


\section{ANEXOS I}

\section{Posicionamento semiótico do Mercedes-Benz Classe A}

1. Levantamento informações da produção:

- A marca Mercedes-Benz é muito valorizada no Brasil.

- Classe A é aprovado para se fabricado no Brasil com uma previsão de vendas de 50.000 unidades ano. 1,7\% de participação de mercado em 2001.

a Produto compacto com todos atributos de tecnologia, segurança e qualidade de um Mercedes-Benz.

- O Classe A é um automóvel compacto, menor que o Ford Ka, com um design inovador que privilegia a redução das dimensões externa do veículo, visando uma maior agilidade nas vias públicas dos grandes centro urbanos.

a Preço definido entre $R \$ 21.000,00$ e $R \$ 25.000,00$ para concorrer contra os compactos Chevrolet Corsa, Fiat Palio e VW Gol, não populares.

- O nome do carro segue o padrão Mercedes-Benz, que dá uma letra seguida das cilindradas do motor no formato de uma centena $=A-$ 160 , a letra se denomina como "classe", portanto Classe A.

- A comercialização ocorrerá nas concessionárias exclusivas para o veículo, cujo o plano é de inaugurar 50 pontos no primeiro ano de comercialização.

a No final de 1997 houve o "teste do alce" prejudicando a imagem do carro, obrigando a matriz alemã a incorporar equipamentos de última geração que elevou o preço do carro em $\mathrm{R} \$ 3.000,00$.

- 1995 -1997 Perspectivas de mercado em expansão.

- Mercado se abre para as importações de automóveis.

- Volume de vendas de automóveis no mercado brasileiro projetado em 3.000.000 para o ano 2001. 
a Em 1997 o mercado chega perto dos 2.000 .000 de veículos ano.

- O Classe A será lançado em nível nacional, porém concentrado nas grandes capitais.

- Em pesquisas foi apurado que o público vê o Classe A como um carro pequeno, o "popular da Mercedes" para lutar no mercado brasileiro.

- Orçamento agressivo para o lançamento

- Muitas notícias favoráveis na imprensa davam conta de um novo Mercedes "popular".

- Com o auge da Internet muitos buscam informações a respeito do "teste do alce" onde o carro capotou - Imprensa brasileira dá cobertura discreta.

a Relançamento na Europa em fevereiro de 1998, aqui no Brasil grande público aguarda com ansiedade o popular da Mercedes.

- Salão do Automóvel de 1998 apresenta Classe A num ambiente inovador (estilo Disney) criando grande expectativa. Foi anunciado um preço de US $\$ 25.000,00$. O Dólar estava com equivalência de um para um em relação ao Real.

2. Sistema de recepção (aferidos em pesquisas quantitativas e qualitativas em 1997)

- O público comprador de carro novo no Brasil dá muita importância ao design, ao conforto e motorização. Dá pouca importância para a segurança. $O$ carro é um objeto extremamente desejado pelo brasileiro.

- A maioria utiliza o carro na cidade, como meio de transporte para o trabalho, para fazer compras e para sair com a família.

- Embora o público comprador de carro novo feminino está crescendo, $68 \%$ ainda é masculino. 
- A faixa etária mais significativa está entre 31 a 45 anos, sendo $731 \%$ casado.

a Renda familiar de $R \$ 2.600,00$ a $R \$ 8.000,00$.

- $50 \%$ compram carro financiado a cada dois anos.

- Gostam de aventura com pouco risco, a família deve estar junta e em segurança.

- Analisa custo benefício na compra de um carro.

- A marca Mercedes-Benz é um sonho de consumo.

- É uma marca inatingível, só para ricos.

- Percebe o Classe A como um carro pequeno.

- Pouco luxo para um Mercedes.

- Dissonante para com a marca Mercedes-Benz "seria ótimo se fosse um Fiat".

- Marca é muito importante, porém o Classe ficou percebido como carro popular, apesar das inovações tecnológicas e dos inúmeros itens de segurança.

- Havia disposição, na comparação com os compactos não populares (Gol 1.6, Palio 1.6 etc.) de se pagar mais caro pela marca, o preço de $R \$ 25.000,00$ pareceu justo para o público.

a Design muito inovador polarizando opiniões entre magnífico e horrível.

- Os compradores de carros compactos afirmaram grande intenção de compra.

- Segmentos superiores como de médios e grandes considerariam a compra como segundo carro da família por $\mathrm{R} \$ 25.000,00$.

a Público consumidor ávido por novidades. 
4. Levantamento as informações do contexto.

- O mercado vive o sonho do Real valorizado.

- Muitos produtos importados entram pela primeira vez em contato com o consumidor brasileiro

- A democracia brasileira está consolidada, porém se agravam os problemas com a má distribuição de renda: violência, baixo nível da educação, concentração urbana, etc.

- A economia mostra sinais de vulnerabilidade às crises externas.

- A globalização e os novos meios de comunicação via Internet trazem as notícias de todo o mundo em tempo real.

- Os impostos, embora privilegiando os carros populares, sobrecarregam os custos de um automóvel.

- A concorrência das marcas tradicionais no Brasil está preocupada com a invasão das novas montadoras.

- As montadoras há mais tempo no Brasil estão defasadas tecnologicamente em relação às novas entrantes no mercado.

- As montadoras tradicionais contam com uma melhor, mais preparada e maior rede de distribuição.

5. Caminho de geração do discurso do posicionamento - Estrutura semionarrativa profunda.

Nessa fase será selecionado o conceito fundamental que servirá de base para o posicionamento, expressando a dialética entre a produção e a recepção. Para isto será montado um quadro comparativo dos valores funcionais e emocionais (de base) para a localização nos quadrantes do mapa semiótico.

Quadro de dialética entre os sistemas de produção e recepção no contexto do mercado 


\begin{tabular}{|l|l|l|l|}
\hline $\begin{array}{l}\text { Valores } \\
\text { Funcionais }\end{array}$ & Produção & Recepção & $\begin{array}{l}\text { Importância para } \\
\text { Recepção (1 5) }\end{array}$ \\
\hline Aerodinâmica & Sim & Não & 4 \\
\hline Presença & Sim & Sim & 4 \\
\hline Estilo & Sim & Sim & 4 \\
\hline Aparência Inter. & Não & Não & 5 \\
\hline Aparência Exter. & Sim & Não & 5 \\
\hline Manobrável & Sim & Sim & 5 \\
\hline Silencioso & Sim & Sim & 5 \\
\hline Visibilidade & Sim & Sim & 5 \\
\hline Luxo & Não & Não & 5 \\
\hline Conforto & Não & Não & 5 \\
\hline Fácil acesso & Sim & Sim & 5 \\
\hline Espaço inter. & Sim & Não & 5 \\
\hline Espaço p. malas & Sim & Não & 5 \\
\hline Qualidade & Sim & Sim & 3 \\
\hline Robustez & Sim & Não & 4 \\
\hline Boa Mecânica & Sim & Sim & 5 \\
\hline Acabamento & Sim & Sim & 3 \\
\hline Tecnologia & Sim & Sim & 3 \\
\hline Motor potente & Sim & 3 \\
\hline Cambim & Sim & 3 \\
\hline Fácil manut. & Sim & Sim & 5 \\
\hline Peças baratas & Sim & 3 \\
\hline Segurança & Sim & \\
\hline
\end{tabular}




\begin{tabular}{|c|c|c|c|}
\hline Alarme & Não & Sim & 3 \\
\hline $\begin{array}{l}\text { Baixo Custo de } \\
\text { manutenção }\end{array}$ & Sim & Não & 3 \\
\hline Custo / Benefício & Sim & Não & 4 \\
\hline Boa revenda & Sim & $\operatorname{Sim}$ & 4 \\
\hline Econômico & Sim & $\operatorname{Sim}$ & 4 \\
\hline \multicolumn{4}{|l|}{ Valores de Base } \\
\hline Aventureiro & Não & Não & \\
\hline Ambicioso & Sim & Não & \\
\hline Familiar & Nào & Sim & \\
\hline Saudável & Sim & Sim & \\
\hline Atlético & Não & Não & \\
\hline Convivência & Sim & $\operatorname{Sim}$ & \\
\hline Confiável & Sim & $\operatorname{Sim}$ & \\
\hline Sociabilidade & Sim & Sim & \\
\hline Empreendedor & Sim & Sim & \\
\hline Prestígio & Sim & Sim & \\
\hline Egoísta & Não & Não & \\
\hline Hedonista & Não & Não & \\
\hline Narcisista & Sim & Não & \\
\hline Clássico & Sim & $\operatorname{Sim}$ & \\
\hline Relaxado & Não & Não & \\
\hline Desfrutador & Não & Não & \\
\hline Inovador & Sim & Sim & \\
\hline
\end{tabular}




\begin{tabular}{|l|l|l|l|}
\hline Dinâmico & Sim & Sim & \\
\hline Jovial & Não & Sim & \\
\hline
\end{tabular}

Os critérios para seleção dos atributos funcionais serão os que apresentarem uma correlação afirmativa nas duas colunas, de produção e recepção, limitados a uma nota acima de quatro. A posição afirmativa ou negativa na coluna da produção foi baseada nos catálogos da montadora; as posições da recepção, bem como a valorização de cada item, foram extraídas da pesquisa de compradores de carros novos. São eles:

- Presença

- Estilo

๑ Manobrável

口 Silencioso

๑ Visibilidade

- Boa mecânica

- Bom preço de revenda

๑ Econômico

- Facilidade para entrar e sair (acesso)

Os critérios para escolha dos atributos emocionais, ou de base, foram a correspondência entre o perfil do público comprador de carros novos, extraído de pesquisa psicográfica, e os itens atribuídos para o Classe $\mathrm{A}$ em pesquisa qualitativa. São eles:

๑ Saudável

- Pertencer a grupo (convivência e sociabilidade)

๑ Confiável

- Empreendedor 
- Prestigio

- Clássico

口 Dinâmico

- Inovador

\subsection{Mapa semiótico}

Analisando os atributos funcionais percebe-se uma preponderância da praticidade, muito procurada nos veículos urbanos. Quando analisado os atributos emocionais percebe-se alguém que quer comunicar uma sociabilidade. "Sou confiável, saudável por isso quero fazer parte da coletividade". É dinâmico e empreendedor e não demonstra medo em inovar. Portanto o quadrante do mapa semiótico mais apropriado é o da MISSÃO.

Missão, situado entre o Crítico e o Utópico:

- Verificador

- Questionador

- Laboratório (Inovação)

- Nova Sociabilidade

口 Empenho

口 O impossível

๑ Visionário

- Mito Coletivo

Os itens do quadrante missão do mapa semiótico permitem entender o sistema de valoração do público comprador possível do Classe A. O conceito fundamental, a base para a identidade da mercadoria, deverá ser escolhido entre uma seleção de alguns termos mais ajustados à realidade da mercadoria, conforme abaixo.

a Idealista

口 Inovador 


\section{- Empreendedor}

A escolha final, como uma seleção paradigmática para o sujeito entrar em conjunção, deverá considerar o termo possuidor de uma grande carga comunicativa, bem como com um certo grau de diferenciação comparado à concorrência.

Seus principais concorrentes, o Fiat Palio, o VW Gol e o Chevrolet Corsa não apresentam um posicionamento claro, são visto como commodities. Como suas vendas se concentram nas versões com motorização 1.000 cc, a popular, as outras versões com motores compatíveis com o do Classe $A$, quase não aparece na mídia. Os concorrentes secundários, do segmento superior, os médios VW Golf e Chevrolet Astra têm um posicionamento fundamentado na jovialidade e na esportividade.

Analisando o Idealista verifica-se que a conotação cotidiana do termo revela alguém à procura de um ideal além do horizonte, mas firme na mente. O ideal é aquilo que reúne todas as perfeições concebíveis independente da realidade. "Aquilo que é objeto de nossa mais alta aspiração" segundo o dicionário Michaelis.

O idealismo remonta Platão que afirmava ser o mundo dos sentidos apenas uma sombra do mundo das formas, onde residem as versões perfeitas, ideais. Esse modo de pensar se refletiu nas esculturas da arte grega, onde se procura aproximar de um padrão ideal de beleza, em vez de retratar pessoas reais.

Assim pode-se concluir que esse termo encaixa-se muito bem com as aspirações do público do quadrante missão, bem como com a mercadoria como objeto estético, que procurou na engenharia a melhor solução em termos de um automóvel para os grandes centros urbanos; pequeno por fora, mas com bom espaço por dentro; pode não ser o design mais bonito para alguns, mas pode ser o ideal para todos que necessitam de um carro para o transito carregado das grandes cidades.

Os outros termos Inovação e Empreendedor parecem não conter a mesma força temática que Idealista. O primeiro, embora totalmente pertinente ao conjunto significante da mercadoria, corre o risco de passar despercebido, visto ao excesso de mensagens que utiliza esse conceito. O segundo, nos dias de hoje, remete mais para quem procura ter um negócio próprio, essa conotação está contida de certa forma no conceito de ter uma idéia na cabeça, de fazer algo diferente, e, portanto coberto pelo primeiro termo o Idealista. 
Assim o termo escolhido para ser o fundamento da identidade do Classe A foi o Idealista. Voltando para o mapa semiótico trata-se de um "crítico" que busca uma superação por meio da cultura, dos valores morais, da justiça, enfim um "idealista". $\mathrm{Na}$ seqüência o termo deverá subir do abstrato para o concreto nas estruturas, conforme segue o procedimento.

4.2 Definição dos actantes

Sujeito: Mercedes-Benz do Brasil - MBB

Objeto: Uma identidade para o Classe A. "Um coração para o ser de lata".

Destinador: O Marketing e a Semiótica.

Destinatário: A agência de propagada.

Ajudantes: As oportunidades do mercado.

Oponentes: A concorrência e as ameaças do mercado.

6. Estrutura semio-narrativa de superfície.

Sintaxe narrativa

Disjunção:

$\mathrm{PN}=\mathrm{F}[\mathrm{S} 1--->(\mathrm{S} 2 \mathrm{U} \mathrm{O})]$ onde:

$\mathrm{PN}=$ Programa Narrativo

$\mathrm{F}=$ Função - Elaborar um discurso contendo uma descrição da identidade do Classe A.

S1 = Sujeito de fazer - MBB (Mercedes-Benz do Brasil)

$\mathrm{S} 2=$ Sujeito de estado $-\mathrm{MBB}$

$\mathrm{O}=$ Objeto susceptível de receber um investimento semântico sob a forma de um valor - Identidade do Classe A.

[ ] = Enunciado de fazer

\{\}$=$ Enunciado de estado

----> = Função fazer 
$\cap U$ = Junção (Conjunção e disjunção) que indica o estado final, a conseqüência do fazer

O Classe A, para ser lançado no mercado, necessita de um posicionamento, para isto a Mercedes-Benz, através do Departamento de Marketing, tem que escolher um conceito fundador para a identidade do veículo e produzir um discurso para entregá-lo a agencia de propaganda.

O sujeito de fazer, MBB, quer fazer sua função de encontrar o objeto, a identidade do Classe $A$, que está perdida no mercado.

O sujeito de estado MBB não sabe como fazer para encontrar a identidade.

Contrato:

O destinador, marketing semiótico, oferece ao sujeito metodologias e pesquisas para esse conseguir escolher uma identidade para o veículo.

A MBB aceita a proposta

Competência:

A MBB elabora as pesquisa de mercado, a segmentação e a definição do público comprador do Classe $\mathrm{A}$, tornando-se habilitado para realizar sua tarefa.

Desempenho:

Com o saber fazer das ferramentas de marketing e da semiótica a MBB sai para o mercado procurando a identidade do Classe $A$, e com a colaboração dos ajudantes, configuração do produto e as oportunidades de mercado, ele enfrenta seus oponentes, a concorrência e as ameaças de mercado, e consegue encontrar uma identidade para o Classe A entrando em conjunção com o objeto desejado.

Conjunção

$$
\mathrm{PN}=\mathrm{F}[\mathrm{S} 1 \quad---->(S 2 \cap \mathrm{O})]
$$




\section{Sansão}

O sujeito entrega o discurso do posicionamento contendo a identidade do Classe A para a agência de propaganda, para que ela prepare corretamente a campanha de lançamento do carro.

A história, para fins desse trabalho, para por aqui, mas na verdade ela continua nas mãos da agência e da MBB, para elaborar toda a campanha de lançamento considerando que o posicionamento deverá permear todos os meios.

Tabela XIV - Comparativo de configuração de produto.

\begin{tabular}{|c|c|c|c|c|}
\hline \multicolumn{5}{|c|}{ Comparativo de configuração de produto } \\
\hline & Palio $1.88 v$ & Gol 1.6 & Corsa 1.8 & A 160 Classic \\
\hline Preço & $\mathrm{R} \$ 27.794,20$ & $\mathrm{R} \$ 28.142,00$ & $\mathrm{R} \$ 28.912,79$ & \\
\hline Portas & 5 & 5 & 5 & 5 \\
\hline Ocupantes & 5 & 5 & 5 & 5 \\
\hline Motor & $1.88 \mathrm{v}$ fire & 1.6 & $1.88 \mathrm{v}$ & $1.68 \mathrm{v}$ \\
\hline Combustível & Gasolina & Gasolina & Gasolina & Gasolina \\
\hline Potência (cv) & 103 & 92 & 102 & 102 \\
\hline Torque (kgfm) & 17 & 13,9 & 16,8 & 15,3 \\
\hline Aceleração (0-100) & 9,5 & 11,7 & 10,9 & 11,3 \\
\hline Velocidade $(\mathrm{km} / \mathrm{h})$ & 186 & 179 & 179 & 180 \\
\hline Consumo Cidade (km/l) & $\mathrm{N} / \mathrm{d}$ & $\mathrm{N} / \mathrm{d}$ & 11 & 10 \\
\hline Consumo Estrada (km/l) & $\mathrm{N} / \mathrm{d}$ & $\mathrm{N} / \mathrm{d}$ & 16,5 & 16 \\
\hline Direção & Hidráulica & Hidráulica & Mecânica & $\begin{array}{l}\text { Hidráulica } \\
\text { eletrônica }\end{array}$ \\
\hline Câmbio & $\begin{array}{c}\text { Manual de cinco } \\
\text { marchas }\end{array}$ & $\begin{array}{c}\text { Manual de } \\
\text { cinco marchas }\end{array}$ & $\begin{array}{l}\text { Manual de } 5 \\
\text { velocidades }\end{array}$ & $\begin{array}{c}\text { Mecânico de cinco } \\
\text { marchas }\end{array}$ \\
\hline Freio Dianteiro & Discos ventilados & $\begin{array}{c}\text { Discos } \\
\text { ventilados }\end{array}$ & Discos ventilados & Disco ventilado \\
\hline Freio Traseiro & Tambores & Tambores & Tambores & Tambor \\
\hline Comprimento (mm) & 3827 & 3883 & 3822 & 3575 \\
\hline Altura $(\mathrm{mm})$ & 1446 & 1415 & 1432 & 1598 \\
\hline Largura $(\mathrm{mm})$ & 1634 & 1621 & 1646 & 1719 \\
\hline Entre-eixos (mm) & 2373 & 2468 & 2491 & 2423 \\
\hline Peso (kg) & 1010 & 947 & 1065 & 1085 \\
\hline Porta-Malas (It) & 290 & 285 & 260 & 350 \\
\hline Tanque (It) & 48 & 51 & 44 & 54 \\
\hline Air Bag & Opcional & Opcional & Opcional & Série \\
\hline Direção Hidráulica & Série & Série & Opcional & Série \\
\hline Ar Condicionado & Opcional & Opcional & Opcional & Série \\
\hline Alarme & - & Opcional & Opcional & - \\
\hline Freio ABS & Opcional & Opcional & Opcional & Série \\
\hline
\end{tabular}




\section{Estrutura discursiva}

O discurso do posicionamento deve conter, na sua forma básica, todos os elementos principais que vão contribuir para comunicar ao público uma mensagem coesa e verossímil. Sendo assim os actantes definidos anteriormente passam a atuar no tempo e no espaço seguindo o conceito fundamental e a sintaxe já definida.

A MBB sai em busca de uma identidade para o seu novo lançamento, o Classe A. Estuda o mercado e se capacita para escolher a essência da mensagem, que é definida como idealista. Elaborar o discurso do posicionamento é permear toda a estratégia de marketing com esse conceito.

O comparativo mostrado na tabela acima ilustra os vários "oponentes" que devem ser combatidos pelos "ajudantes". O conceito fundamental escolhido deverá então prevalecer nas escolhas dos itens do produto, assim não se pode falar de um carro ideal que não tenha ar condicionado de série.

$\mathrm{Na}$ discursivização os ajudantes são: O preço básico sugerido, os itens de série e os opcionais, as características do motor, as dimensões, enfim as variáveis principais, percebidas pelo público. Já os oponentes são os mesmos itens porém presentes na concorrência.

Como ilustração foi deixado o preço real do Classe A para mostrar a dissonância em relação à concorrência. Nesse caso o oponente conseguiu vencer o ajudante e provavelmente impediu o sujeito de entrar em conjunção com o seu objeto, pois um carro como o Classe $A$, com o valor $R \$ 10.000,00$ mais caro que seus concorrentes diretos, não vai conseguir passar a imagem de ser um idealista.

Partindo do princípio que esses itens somente seriam definidos após o posicionamento, seguindo a metodologia do marketing tradicional, aonde o posicionamento vem depois da pesquisa de mercado, da segmentação e da seleção do público, fica claro decidir sobre as variáveis sabendo o conceito básico.

Com a ajuda dos mapas semióticos; números 10,11 e 12; será possível prosseguir na actorialização, espacialização e temporalização para se chegar ao discurso. 
O sujeito MBB assume o papel de um pioneiro, por trazer para o Brasil um carro tão à frente do seu tempo.

O destinador, marketing semiótico, será reconhecido no discurso como um sábio, um mago, que com suas artimanhas preparou o sujeito para a sua tarefa.

O destinatário vai ser assumido por dois atores, o primeiro a agencia de propaganda, que tem como tarefa elaborar uma campanha que seja condizente com o discurso do posicionamento. O segundo será o público que receberá as mensagens e o carro em si, impregnado pelo discurso do posicionamento, nesse último caso o ator será um cidadão.

Os ajudantes, preço, produto, distribuição serão os indivíduos empenhados em oferecer sempre um excelente serviço para o cidadão.

Os oponentes, inferiorizados nos aspecto físicos, contam com a ajuda das ameaças dos revezes da situação econômica, no que diz respeito às taxas de cambio, pois o Classe A possui $70 \%$ de seus componentes importados da Alemanha. Esse é um risco assumido pela empresa, cuja solução é, conforme for ganhando escala de produção, nacionalizar esses componentes.

\section{Espacialização}

A pioneira MBB fabrica no Brasil, entre as montanhas de Minas Gerais, berço de artistas e poetas.

\section{Temporalização}

A pioneira MBB fabrica no Brasil, entre as montanhas de Minas Gerais, berço de artistas e poetas, pela primeira vez fora da Alemanha o futuro no presente.

Para dar maior objetividade ao texto será utilizada a terceira pessoa, o objetivo desse discurso será persuadir a agencia de propagada a preparar suas mensagens e o posicionamento final "slogan de campanha" dentro da proposta trabalhada, sem "excessos de criatividade" que se descolam do conjunto significante, prejudicando o sentido apreendido pelo público. 
Quanto à semântica discursiva, visto que o discurso servirá de base para criação da campanha e do slogan, é mais seguro utilizar os recursos da figurativização, para dar a mensagem uma ligação mais intima com a realidade.

7. Plano de manifestação - $O$ discurso do posicionamento para a agência de propaganda.

A Mercedes-Benz, pioneira na fabricação de automóveis no mundo, traz para o Brasil sua primeira fábrica fora da Alemanha, instalada entre as montanhas de Minas Gerais, berço de artistas e poetas, para cumprir um ideal: produzir o Classe A, um automóvel que traz uma perfeita combinação de design (a gota é a forma aerodinâmica mais perfeita), dirigibilidade, visibilidade, confiabilidade e prestígio da marca, sem sair da realidade do bolso do brasileiro. Projetado para quem aspira ser um cidadão de um mundo melhor, para quem esperava ver a forma perfeita materializada com a tecnologia da mais clássica das marcas de automóveis.

Síntese:

O Classe A é o carro perfeito para o cidadão que acredita que seus ideais se tornarão realidade.

\subsection{Análise comparativa}

Antes de se efetuar a análise comparativa se faz necessário determinar alguns parâmetros para a mesma. Do lado do procedimento tradicional é de fundamental importância excluir o fato da desvalorização do Real frente ao Dólar, ocorrida pouco antes do lançamento do Classe $A$, que provocou um incremento nos custos dos componentes importados, refletindo diretamente no preço final para o público.

Nessa análise será admitida a hipótese de que o Classe A teria sido lançado pelo preço que foi projetado quando da elaboração do posicionamento original. Dizer que a vulnerabilidade da moeda brasileira deveria ter sido prevista pelos analistas da empresa, e por conseqüência considerada no posicionamento, é um fator que foge 
do objetivo desse trabalho, que é o de mostrar as possibilidades de utilização das ferramentas semióticas no marketing.

Procedimento para posicionamento

\begin{tabular}{|c|c|}
\hline Semiótico & Tradicional \\
\hline $\begin{array}{l}\text { 1. Levantamento de informações. } \\
\text { Leva em consideração a } \\
\text { comunicação entre a marca, } \\
\text { mercadoria, concorrência e o público } \\
\text { receptor. }\end{array}$ & $\begin{array}{l}\text { 1. Pesquisa de mercado, } \\
\text { Segmentação e Definição do público } \\
\text { alvo. Leva em consideração a } \\
\text { opinião do entrevistado. }\end{array}$ \\
\hline $\begin{array}{l}1.1 \text { A preocupação é com os valores } \\
\text { do consumo. Administração de } \\
\text { valores }\end{array}$ & $\begin{array}{l}\text { 1.1 Preocupação em obter uma massa } \\
\text { economicamente viável com } \\
\text { homogeneidade. Administração de } \\
\text { demanda. }\end{array}$ \\
\hline $\begin{array}{l}\text { 2. Dialética entre produção e } \\
\text { recepção. Mercadoria é meio de } \\
\text { comunicação, ela possui um valor } \\
\text { semântico que é incorporado pelo } \\
\text { consumidor. Consumir é comunicar. }\end{array}$ & $\begin{array}{l}\text { 2. O foco na satisfação de } \\
\text { necessidades e desejos. Mercadoria } \\
\text { meio para troca. }\end{array}$ \\
\hline $\begin{array}{l}\text { 3. O contexto é considerado como } \\
\text { componente que influencia a } \\
\text { valorização do consumo. Procura-se } \\
\text { identificar fatos que poderão num } \\
\text { futuro modificar valores e } \\
\text { conseqüentemente comportamentos. } \\
\text { Foco no consumo, responsável pela } \\
\text { criação da cultura onde o consumidor } \\
\text { vive imerso. }\end{array}$ & $\begin{array}{l}\text { 3. O contexto é considerado como } \\
\text { uma foto do momento. Oportunidades } \\
\text { e ameaças não enfocam valores } \\
\text { emocionais e simbólicos. } \\
\text { É elaborada uma análise de forças e } \\
\text { fraquezas vs. oportunidades e } \\
\text { ameaças. } \\
\text { Foco no consumidor, porém este } \\
\text { não é um ser independente que faz } \\
\text { escolhas individuais, ele é mutante e } \\
\text { mutável conforme muda a cultura de } \\
\text { consumo. }\end{array}$ \\
\hline 4. Valores funcionais e simbólicos são & 4. Posicionamento é elaborado tendo \\
\hline
\end{tabular}




\begin{tabular}{|c|c|}
\hline $\begin{array}{l}\text { analisados para se chegar a um } \\
\text { quadro de valorização do consumo. }\end{array}$ & $\begin{array}{l}\text { como princípio um benefício-chave da } \\
\text { mercadoria, geralmente apoiado nas } \\
\text { características funcionais desta, a ser } \\
\text { implantado na mente do público } \\
\text { identificado como alvo. }\end{array}$ \\
\hline & $\begin{array}{l}\text { 4.1 Um briefing técnico é passado } \\
\text { para a agencia de propaganda. É } \\
\text { delegado à agencia todo o trabalho } \\
\text { estratégico de delimitar as possíveis } \\
\text { leituras das mensagens (Isotopias) }\end{array}$ \\
\hline $\begin{array}{l}\text { 5. Inicia-se o percurso de geração de } \\
\text { significação que aportará à } \\
\text { mercadoria um sentido, uma } \\
\text { identidade, baseado em um conceito } \\
\text { fundamental a ser selecionado no } \\
\text { mapa semiótico. O Objetivo é } \\
\text { produzir um pequeno enunciado, } \\
\text { que descreverá o conceito } \\
\text { fundamental encontrado, para } \\
\text { apresentá-lo à agencia de } \\
\text { propaganda. }\end{array}$ & \\
\hline RESULTADO SEMIÓTICO & RESULTADO TRADICIONAL \\
\hline $\begin{array}{l}\text { A Mercedes-Benz, pioneira na } \\
\text { fabricação de automóveis no mundo, } \\
\text { traz para o Brasil sua primeira fábrica } \\
\text { fora da Alemanha, instalada entre as } \\
\text { montanhas de Minas Gerais, berço de } \\
\text { artistas e poetas, para cumprir um } \\
\text { ideal: produzir o Classe A, um } \\
\text { automóvel que traz uma perfeita } \\
\text { combinação de design (a gota é a } \\
\text { forma aerodinâmica mais perfeita), }\end{array}$ & $\begin{array}{l}\text { Classe A, um compacto premium, um } \\
\text { verdadeiro Mercedes-Benz, fabricado } \\
\text { no Brasil, ao alcance da classe média } \\
\text { brasileira, com tecnologia e segurança } \\
\text { incomparáveis. }\end{array}$ \\
\hline
\end{tabular}




\begin{tabular}{|lr|}
\hline dirigibilidade, visibilidade, & \\
confiabilidade e prestígio da marca, & \\
sem sair da realidade do bolso do & \\
brasileiro. Projetado para quem aspira & \\
ser um cidadão de um mundo melhor, \\
para quem esperava ver a forma \\
perfeita materializada com a \\
tecnologia da mais clássica das \\
marcas de automóveis. \\
Síntese: \\
A Mercedes-Benz fez o Classe A, o \\
carro perfeito para o cidadão que \\
acredita que seus ideais se tornarão \\
realidade.
\end{tabular}

O posicionamento semiótico oferece como vantagem, em relação ao tradicional a possibilidade de transmitir para a agência de propaganda a essência do valor semântico da mercadoria, aquilo que será objeto de comunicação entre a mercadoria e o seu público, e o público com seu grupo. Consegue também definir os papéis que cada ator: fabricante, mercadoria, público, agencia, concorrência etc. vai desempenhar dentro de uma leitura possível, garantido uma homogeneidade da mensagem, independente do meio.

Os itens em negrito estabelecem as principais diferenças vantajosas do procedimento semiótico em vista do tradicional. Todos os itens já foram comentados nos capítulos anteriores e estão embasados nas teorias que formam o referencia teórico desse trabalho.

O resultado para o público do posicionamento tradicional foi o slogan de lançamento: "VOCÊ DE MERCEDES". Desconsiderando o fator preço, este slogan foi infeliz, pois a mercadoria, sem o badget da Mercedes na grade, a estrela de três pontas, em momento algum, visualmente falando, comunica que é um MercedesBenz. É um Mercedes, mas não se parece como tal. "Semióticamente" é um segredo 
que tem que ser revelado, ora se é necessário explicar alguma coisa, já não se estabelece uma comunicação efetiva.

O Fato da mercadoria não se parecer um Mercedes entra em conflito com as mensagens provenientes desse slogan. A intenção de mostra que comprar o Classe A era um sonho se realizando, presente nas mensagens televisivas, não convencia um público que esperava comunicar ao seu grupo, que agora ele fazia parte do restrito clube, o das pessoas que possuíam um Mercedes.

A mensagem também escorregou nos corredores isotópicos, pois a música utilizada, wish upon a star, trilha sonora do filme Pinóquio, bem como as fotos de pessoas segurando uma miniatura do Classe A nas mão, remetiam ao um sonho de criança, e não a um sonho de adulto proposto pelo posicionamento. Muitos dos consumidores de automóveis declararam na época que o Classe A passava uma impressão de fragilidade.

Obviamente não se tem a tradução do discurso do posicionamento semiótico para o público. Mas é fácil concluir que os problemas ocorridos com o Classe $A$ poderiam terem sido evitados com a aplicação das ferramentas semióticas.

Primeiramente o tema idealista é totalmente pertinente às características do carro. Faz parte da valorização de uma parcela dos compradores de carros novos que apreenderiam a mensagem como uma verdade, pois é a pioneira MercedesBenz, uma das melhores marcas do mundo falando.

O tema contém também certa carga de responsabilidade social, mais pertinente aos dias de hoje que o arrogante "Você de Mercedes". Pois o ideal de um cidadão passa pelo bem estar de toda a comunidade.

Comparando suas funcionalidades com a concorrência o Classe A é muito superior o que facilita a verossimilhança com a mensagem de perfeição, alem de 0 diferenciar nitidamente.

Com o todo esse material a agência certamente encontraria um terreno fértil para criação de suas mensagens para o público. 


\section{ANEXO II}

Tabela de preços e volume de vendas em 2007 de utilitários esportivos

SUB SEGMENTO
UTILITÁRIO ESPORTIVO PEQUENO
UTILITÁRIO ESPORTIVO PEQUENO
UTILITÁRIO ESPORTIVO PEQUENO
UTILITÁRIO ESPORTIVO PEQUENO
UTILITÁRIO ESPORTIVO PREMIO
UTILITÁRIO ESPORTIVO PEQUENO
UTILITÁRIO ESPORTIVO MÉDIO
UTILITÁRIO ESPORTIVO PEQUENO
UTILITÁRIO ESPORTIVO PEQUENO
UTILITÁRIO ESPORTIVO PREMIO
UTILITÁRIO ESPORTIVO MÉDIO
UTILITÁRIO ESPORTIVO MÉDIO
UTILITÁRIO ESPORTIVO MÉDIO
UTILITÁRIO ESPORTIVO MÉDIO
UTILITÁRIO ESPORTIVO MÉDIO
UTILITÁRIO ESPORTIVO PREMIO
UTILITÁRIO ESPORTIVO MÉDIO
UTILITÁRIO ESPORTIVO MÉDIO
UTILITÁRIO ESPORTIVO MÉDIO
UTILITÁRIO ESPORTIVO PREMIO
UTILITÁRIO ESPORTIVO PREMIO
UTILITÁRIO ESPORTIVO PREMIO
UTILITÁRIO ESPORTIVO MÉDIO
UTILITÁRIO ESPORTIVO PREMIO
UTILITÁRIO ESPORTIVO PREMIO
UTILITÁRIO ESPORTIVO MÉDIO
UTILITÁRIO ESPORTIVO PREMIO
UTILITÁRIO ESPORTIVO PREMIO
UTILITÁRIO ESPORTIVO PREMIO
UTILITÁRIO ESPORTIVO PREMIO
UTILITÁRIO ESPORTIVO MÉDIO
UTILITÁRIO ESPORTIVO PREMIO
UTILITÁRIO ESPORTIVO PREMIO
UTILITÁRIO ESPORTIVO MÉDIO
UTILITÁRIO ESPORTIVO PREMIO
UTILITÁRIO ESPORTIVO PREMIO
UTILITÁRIO ESPORTIVO PREMIO
UTILITÁRIO ESPORTIVO PREMIO
UTILITÁRIO ESPORTIVO PREMIO

MARCA

FORD

VOLKSWAGEN

HYUNDAI

MITSUBISHI

TOYOTA

GENERAL MOTORS

MITSUBISHI

CHRYSLER

KIA

MITSUBISHI

GENERAL MOTORS

HONDA

HYUNDAI

MITSUBISHI

LAND ROVER

LAND ROVER

TOYOTA

KIA

TROLLER

TOYOTA

HYUNDAI

LAND ROVER

NISSAN

CHRYSLER

PORSCHE

CHRYSLER

BMW

MERCEDES-BENZ

VOLKSWAGEN

BMW

SUBARU

NISSAN

VOLVO

NISSAN

VOLVO

GENERAL MOTORS

MERCEDES-BENZ

GENERAL MOTORS

AUDI
MODELO

ECOSPORT

CROSSFOX

TUCSON

PAJERO TR4

HILUX SW4

TRACKER

PAJERO SPORT

PT CRUISER

SPORTAGE

PAJERO FULL

BLAZER

CR-V

SANTA FÉ

AIRTREK

FREELANDER

DISCOVERY

RAV4

SORENTO

$\mathrm{T} 4$

LAND CRUISER

VERACRUZ

RANGE ROVER

X-TERRA

GRAND CHEROKEE

CAYENNE

CHEROKEE SPORT

SERIE X5

CLASSE M

TOUAREG

SERIE X3

FORESTER

PATHFINDER

XC90

XTRAIL

XC70

HUMMER H3

CLASSE G

HUMMER H2

Q7
VENDAS

2007 PREÇO (R\$)

$4796150.000,00$

$2731745.000,00$

$1265990.000,00$

$769276.000,00$

$7216153.000,00$

$672960.000,00$

$6159120.000,00$

$242369.000,00$

$227085.000,00$

$2265174.000,00$

2027 133.000,00

$1936 \quad 123.000,00$

$1831 \quad 165.000,00$

$1690 \quad 100.000,00$

1574 169.000,00

$1066237.000,00$

$1066 \quad 129.000,00$

$994142.000,00$

$95381.000,00$

$854172.000,00$

$711185.000,00$

$550 \quad 330.000,00$

$430 \quad 125.000,00$

$369249.000,00$

$323 \quad 350.000,00$

$312120.000,00$

$311370.000,00$

$304286.000,00$

$250 \quad 200.000,00$

$232286.000,00$

$188 \quad 160.000,00$

$160 \quad 183.000,00$

$143263.000,00$

$136121.000,00$

31 198.000,00

$27 \quad 230.000,00$

$25400.000,00$

$11350.000,00$

$6349.000,00$ 
ANEXO III

Publicidade da Revista Caras Edição 766, Ano 15, No. 28 de 11/07/2008

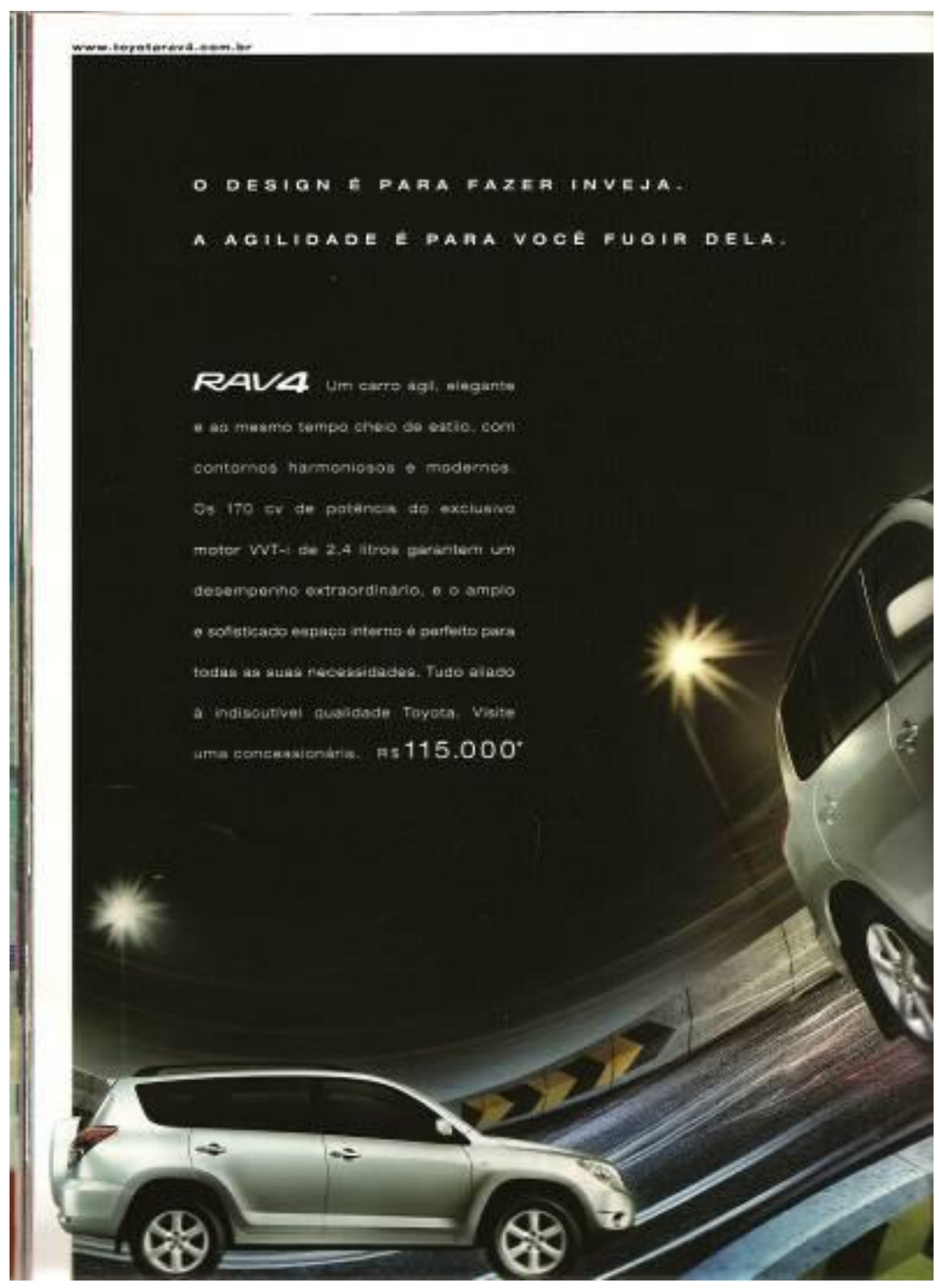




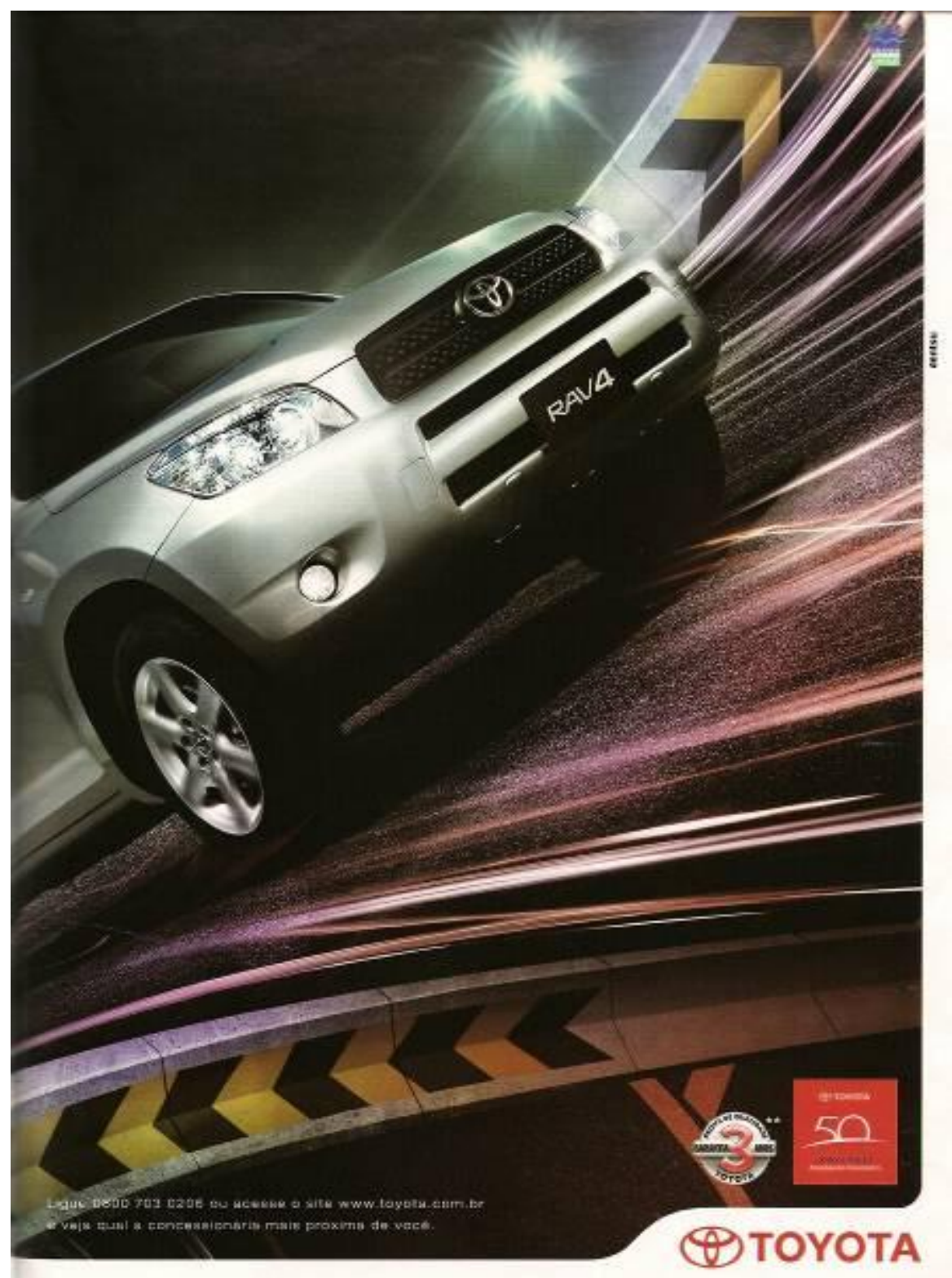


Assim, com os vidros fechados e "filmados", deixo de aparecer, e ele se apresenta como um novo "eu", agora motorizado. 